\title{
3. SILICIFICATION OF DEEP-SEA SEDIMENTS AND THE OXYGEN ISOTOPE COMPOSITION OF DIAGENETIC SILICEOUS ROCKS FROM THE WESTERN PACIFIC, PIGAFETTA AND EAST MARIANA BASINS, LEG $129^{1}$
}

\author{
Richard J. Behl² and Brian M. Smith ${ }^{3}$
}

\begin{abstract}
Ocean Drilling Program Leg 129 recovered chert, porcellanite, and radiolarite from Middle Jurassic to lower Miocene strata from the western Pacific that formed by different processes and within distinct host rocks. These cherts and porcellanites formed by (1) replacement of chalk or limestone, (2) silicification and in-situ silica phase-transformation of bedded clay-bearing biosiliceous deposits, (3) high-temperature silicification adjacent to volcanic flows or sills, and (4) silica phase-transformation of mixed biosiliceous-volcaniclastic sediments.

Petrologic and O-isotopic studies highlight the key importance of permeability and time in controlling the formation of dense cherts and porcellanites. The formation of dense, vitreous cherts apparently requires the local addition and concentration of silica. The influence of permeability is shown by two examples, in which: (1) fragments of originally identical radiolarite that were differentially isolated from pore-water circulation by cement-filled fractures were silicified to different degrees, and (2) by the development of secondary porosity during the opal-CT to quartz inversion within conditions of negligible permeability. The importance of time is shown by the presence of quartz chert below, but not above, a Paleogene hiatus at Site 802, indicating that between 30 and $52 \mathrm{~m} . \mathrm{y}$. was required for the formation of quartz chert within calcareous-siliceous sediments.

The oxygen-isotopic composition for all Leg 129 carbonate- and Fe/Mn-oxide-free whole-rock samples of chert and porcellanite range widely from $\delta^{18} \mathrm{O}=27.8 \%$ to $39.8 \%$ vs. V-SMOW. Opal-CT samples are consistently richer in ${ }^{18} \mathrm{O}(34.1 \%$ to $39.3 \%$ than quartz subsamples $(27.8 \%$ to $35.7 \%$ ). Using the O-isotopic fractionation expression for quartz-water of Knauth and Epstein (1976) and assuming $\delta^{18} \mathrm{O}_{\text {pore water }}=-1.0 \%$, model temperatures of formation are $77^{\circ}-26^{\circ} \mathrm{C}$ for carbonate-replacement quartz cherts, $22^{\circ}-25^{\circ} \mathrm{C}$ for bedded quartz cherts, and $32^{\circ}-34^{\circ} \mathrm{C}$ for thermal quartz cherts. Large variations in $\mathrm{O}$-isotopic composition exist at the same burial depth between co-existing silica phases in the same sample and within the same phase in adjacent lithologies. For example, quartz has a wide range of isotopic compositions within a single breccia sample; $\delta^{18} \mathrm{O}=33.4 \%$ and $28.0 \%$ for early and late stages of fracture-filling cementation, and $31.6 \%$ and $30.2 \%$ for microcrystalline quartz precipitation within enclosed chert and radiolarite fragments. Similarly, opal-CT d $\mathrm{d}_{101}$ spacing varies across lithologic or diagenetic boundaries within single samples.

Co-occurring opal-CT and chalcedonic quartz in shallowly buried chert and porcellanite from Sites 800 and 801 have an $8.7 \%$ difference in $\delta^{18} \mathrm{O}$, suggesting that pore waters in the Pigafetta Basin underwent a Tertiary shift to strongly ${ }^{18} \mathrm{O}$-depleted values due to alteration of underlying Aptian to Albian-Cenomanian volcaniclastic deposits after opal-CT precipitation, but prior to precipitation of microfossil-filling chalcedony.
\end{abstract}

\section{INTRODUCTION}

Cherts have been recovered by marine geologists from all oceans and from within a diverse suite of host lithologies; they are also a key component in many mountain belts where their origin and significance have been much debated (see discussion in Jenkyns, 1986). Although it is now understood that most Phanerozoic chert and porcellanite are the diagenetic descendants of originally biogenous silica, there is still incomplete understanding of the controls of chert formation. However, the paleoenvironment of deposition and the environment of diagenesis (e.g., paleolatitude, paleobathymetry, and burial depth) can be more precisely constrained in sediments recovered from the deep sea than in cherts exposed on land; this factor has led to numerous detailed studies of the diagenesis, petrography, and oxygen isotope composition of deep-sea chert and porcellanite (see reviews in Pisciotto, 1981b, and Hesse, 1988).

Ocean Drilling Program (ODP) Leg 129 drilled Sites 800, 801, and 802 in the Pigafetta and East Mariana basins of the west Pacific (Fig. 1) in a successful search for Jurassic oceanic crust and sediments. The cherts and porcellanites recovered during Leg 129 are particularly suitable for petrologic study for several reasons: (1)

\footnotetext{
${ }^{1}$ Larson, R. L., Lancelot, Y., et al., 1992. Proc. ODP, Sci. Results, 129: College Station, TX (Ocean Drilling Program).

${ }^{2}$ Earth Sciences Department, University of California, Santa Cruz, CA 95064, U.S.A.

${ }^{3}$ Center for Isotope Geochemistry, Earth Sciences Division, Lawrence Berkeley Laboratory, Berkeley, CA 94720, U.S.A. (Current address: Environment, Health and Safety Division, Lawrence Berkeley Laboratory, Berkeley, CA 94720, U.S.A.)
}

included are some of the oldest recovered in-situ siliceous rocks, (2) chert and porcellanite were recovered from a diverse set of host sediments, (3) chert and porcellanite formed in sediments buried at different rates, and (4) siliceous rocks were recovered from a wide age range of strata (Middle Jurassic to lower Miocene) (Fig. 2). We examined a variety of chert, porcellanite, and radiolarite samples that are similar to deep-sea siliceous rocks discussed in detail by Heath and Moberly (1971), Lancelot (1973), Keene (1975, 1976), and Hein et al. (1981). Our petrographic findings are consistent with most of their observations, and we attempt not to duplicate their excellent descriptions; therefore, we limit the scope of this paper to examination of such key controls of the chertification process as time, permeability, burial depth, and temperature. Our petrologic studies highlight the importance of silica mobility in the formation of chert and porcellanite. We discuss several examples illustrating the significance of free fluid movement, including (1) a detailed analysis of how fragments of the same sedimentary rock sustained different degrees of diagenetic alteration in isolated compartments of a breccia, and (2) observations of the development of secondary porosity at the opal-CT to quartz transformation under conditions of limited permeability.

We integrate our petrographic investigation with an oxygen-isotope study of diagenetic siliceous rocks. Previous O-isotopic studies of deep-sea cherts and porcellanites determined the compositional ranges for opal-CT and diagenetic quartz, identified compositional trends through time, and estimated temperatures of crystallization (Knauth and Epstein, 1975; Kolodny and Epstein, 1976; Hein and Yeh, 1981). In this study, we measure the $\mathrm{O}$-isotopic composition of various cherts that formed by different processes or from distinct protoliths, and we 


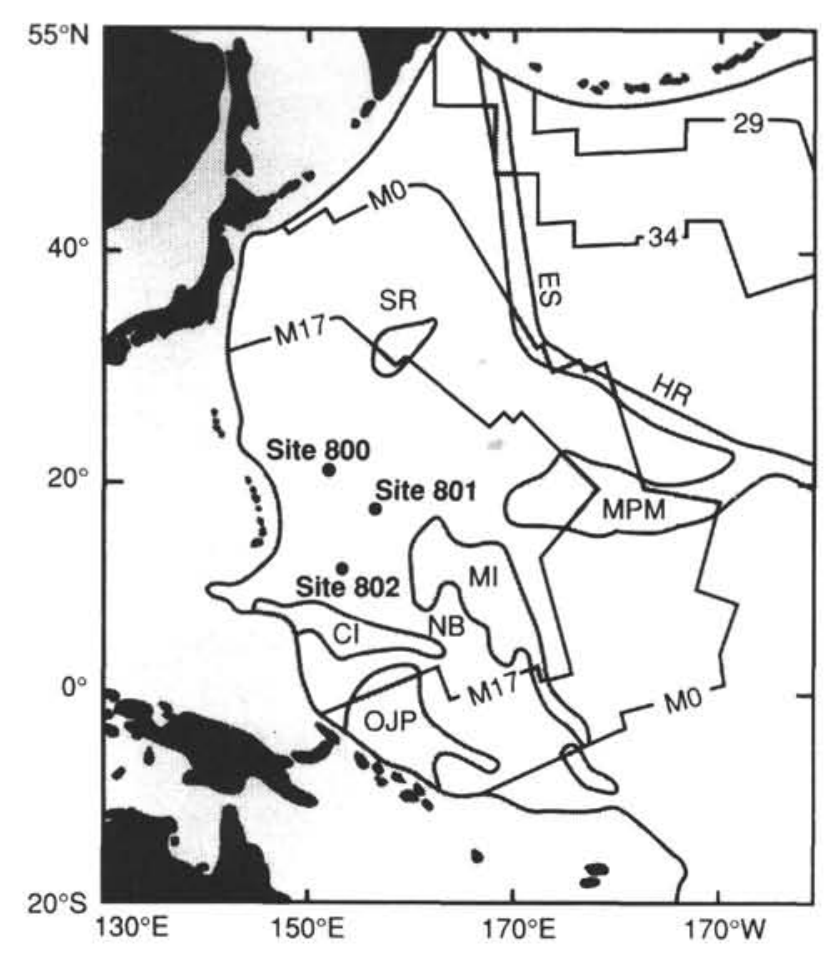

Figure 1. Locations of Leg 129 Sites 800, 801, and 802. Feature abbreviations are: Caroline Islands (CI), Ontong Java Plateau (OJP), Marshall Islands (MI), Nauru Basin (NB), Mid-Pacific Mountains (MPM), Shatsky Rise (SR), Hawaiian Ridge (HR), and Emperor Seamounts (ES). Contours represent magnetic lineations, unshaded areas represent normal Pacific ocean crust, and shaded areas represent volcanic edifices with thickened crustal sections, as well as younger areas west of the Pacific subduction zones.

closely examine variations in $\mathrm{O}$-isotopic composition across diagenetic boundaries and between co-existing opal-CT and quartz phases to clarify diagenetic sequences of silicification.

\section{STRATIGRAPHY AND DISTRIBUTION OF SILICEOUS ROCKS AT SITES 800, 801, AND 802}

Siliceous diagenetic sedimentary rocks were recovered during Leg 129 from all sites drilled in the Pigafetta and East Mariana basins of the western Pacific (Figs. 1 and 2) (Lancelot, Larson, et al., 1990). The three sites of Leg $129(800,801,802)$ are thought to have twice crossed the equator, and the presence of chert, porcellanite, and radiolarite record their passing beneath the high-productivity divergence (Lancelot, Larson, et al., 1990; Ogg et al., this volume). Variations in silica diagenesis, however, can confuse the primary paleoenvironmental signal in the stratigraphic record (Riech and von Rad, 1979), especially as interpreted from the rocks recovered from a small borehole. Although principally derived from radiolarian-rich sediments, the cherts and porcellanites examined in this study formed by a variety of processes and from different sedimentary protoliths, including chalk and limestone, radiolarite, pelagic and volcaniclastic claystone, and hydrothermal deposits (Fig. 2).

All Leg 129 holes were drilled at abyssal depths (5674 to 5969 meters below sea level [mbsf]) into sedimentary and volcanic rocks overlying Middle Jurassic oceanic crust (Fig. 1), although only Hole $801 \mathrm{C}$ penetrated true oceanic basement (Fig. 3) (Lancelot, Larson, et al., 1990). We cored a wide variety of Middle Jurassic to Quaternary pelagic sediments (e.g., radiolarite, radiolarian chert and porcellanite, nannofossil and foraminiferal chalk and limestone, and pelagic clay) at Sites 800,801 and 802, and all holes penetrated Lower to Upper Cretaceous volcanic or volcaniclastic rocks (Fig. 3) (Lance- lot, Larson, et al., 1990). The siliceous rocks examined in this study were recovered from Middle Jurassic to upper Oligocene/lower Miocene strata (Fig. 2) and include the oldest sedimentary rocks yet cored in the Pacific basin.

\section{NOMENCLATURE OF LEG 129 SILICEOUS SEDIMENTARY ROCKS}

\section{Lithology}

Of the chert, porcellanite, and radiolarite samples recovered on Leg 129, almost all are descendants of primary radiolarian-bearing sediments. They are distinguished from each other by the degree of silicification experienced during diagenesis and by secondary mineralogic components. The degree of silicification is also important in that it probably influences the degree to which a pelagic deposit is preserved during emplacement into continental mountain belts and their ultimate likelihood for intact survival in the on-land stratigraphic record. We follow the distinction of Baltuck (1986) between silicification (pore-filling silica cementation) and chertification (silica replacement and pore-filling silica cementation of the host rock into a dense chert). In this report, we follow the definitions of Bramlette (1946), Keene (1975), and Pisciotto (1981a, 1981b) for chert and porcellanite and restrict the ODP definition of radiolarite (Mazzullo et al., 1988), with descriptions as follows:

Chert is the dense, hard, aphanitic siliceous sedimentary rock, composed of either diagenetic quartz or opal-CT, that breaks with a smooth, conchoidal to splintery fracture and that has a vitreous to resinous luster. Most of the Leg 129 cherts are radiolarian cherts.

Porcellanite is less dense and hard than chert, breaks with a matte texture and blocky fracture, and typically has a dull to somewhat waxy luster. The silica of deep-sea porcellanite is usually opal-CT, but can also be diagenetic quartz. The physical appearance (or field characteristics) of chert and porcellanite chiefly reflects the properties of the diagenetic silica cement or matrix; the differences between the two rock types are generally due to increased porosity or nonbiogenic component in porcellanite (Isaacs, 1981). Most Leg 129 porcellanites are radiolarian porcellanites.

The term "radiolarite," in its most general use by geologists, could be used to describe almost all of the siliceous rocks recovered during Leg 129. ODP defines radiolarite as a firm pelagic sediment $(<40 \%$ siliciclastic and volcaniclastic grains), composed predominantly of radiolarians. We restrict the ODP definition to exclude the more compact diagenetic rocks-radiolarian chert and porcellanite. Radiolarite is herein used to describe the siliceous rocks composed of $>50 \%$ radiolarians, that are not sufficiently silica-cemented to meet the textural definitions of radiolarian chert or porcellanite (i.e., smooth or matte fracture). The texture of radiolarite is governed by the abundant radiolarians themselves, rather than the cement or binding matrix, typically resulting in an arenaceous texture and rough, irregular fracture. Petrographically, porosity and clay content are the key observable differences between vitreous radiolarian chert and an adjacent radiolarite or porcellanite. This definition of radiolarite is similar to that of Audley-Charles (1965), but more restricted than that of most Alpine geologists (e.g., Trümpy, 1960; Grunau, 1965). It is critical for this diagenetic study, however, to make clear distinctions between weakly cemented, porous, and permeable radiolarite and silicified, hard, brittle, and relatively impermeable chert or porcellanite.

\section{Silica Phases}

We use the definitions of Jones and Segnit (1971) for opal-A and opal-CT. Opal-A is the hydrous, X-ray amorphous form of biogenic silica that forms sponge spicules and the tests of radiolarians and diatoms. Opal-CT (cristobalite/tridymite) is the metastable form of diagenetic silica that usually develops as an intermediate phase between opal-A and diagenetic quartz. Flörke (1955) interpreted the structure of opal-CT to be unidimensionally disordered $\alpha$-cristobalite. 


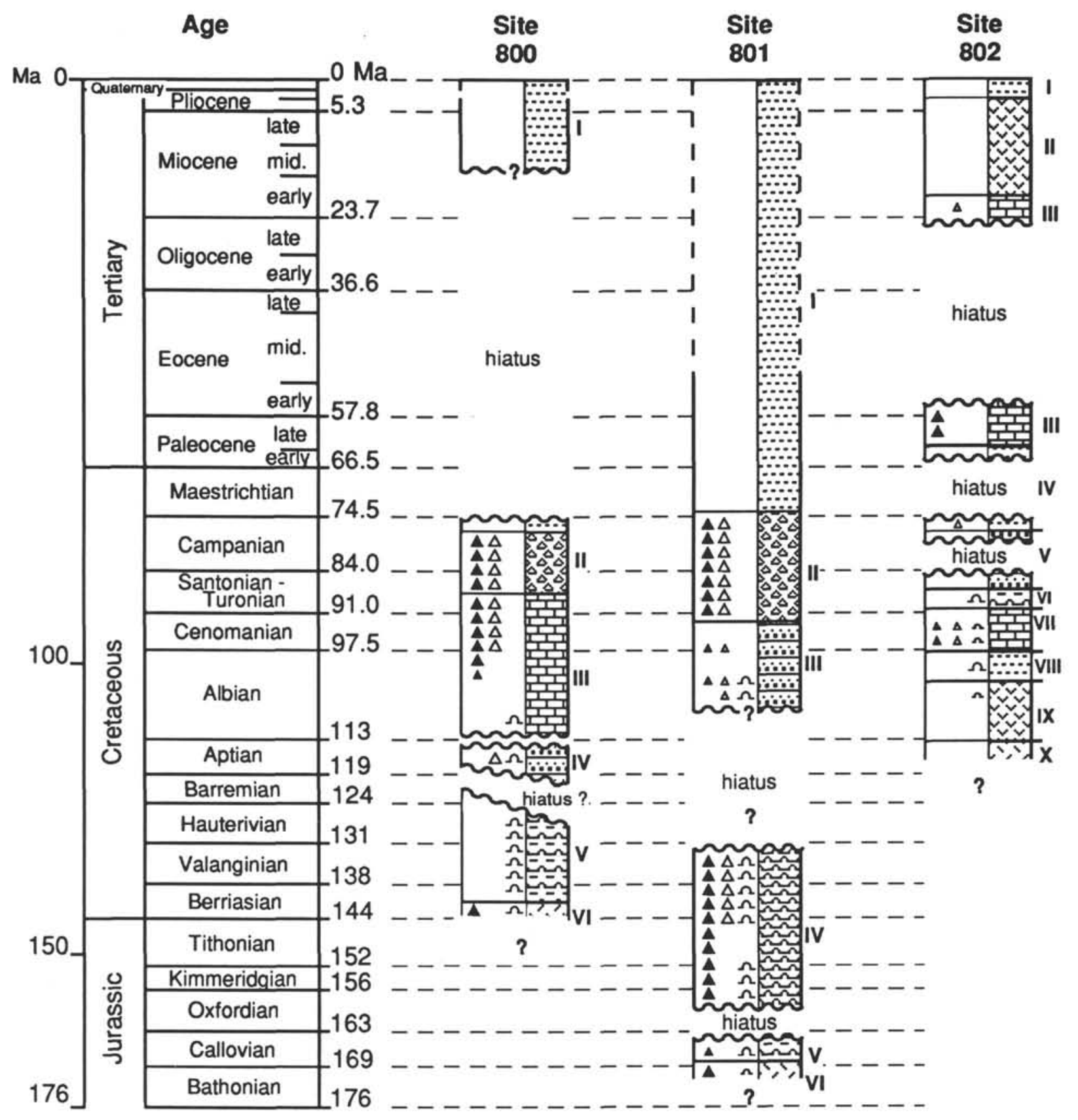

\begin{tabular}{|c|c|c|c|c|c|}
\hline $\begin{array}{r}\text { Siliceous Rocks } \begin{array}{r}\text { Chert } \\
\text { Porcellanite } \\
\text { Radiolarite }\end{array} \\
\text { No Siliceous Rocks }\end{array}$ & 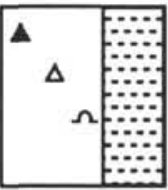 & $\begin{array}{l}\text { Associated or } \\
\text { Host Lithology }\end{array}$ & $\begin{array}{r}\text { Abunda } \\
\text { Co } \\
\text { Mir }\end{array}$ & $\begin{array}{l}\text { ince } \\
\text { mmon: } \\
\text { nor: }\end{array}$ & $\begin{array}{l}\Delta \Delta \Omega \\
\Delta \Delta \Omega\end{array}$ \\
\hline Host Lithologies & 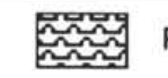 & Radiolarite & 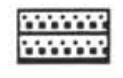 & \multicolumn{2}{|c|}{$\begin{array}{l}\text { Volcaniclastic } \\
\text { Turbidites }\end{array}$} \\
\hline 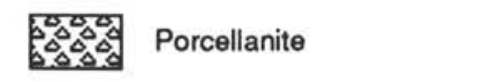 & مَت & Clay and Radiolarite & $\sqrt{2 \times 2 \times 2}$ & \multicolumn{2}{|l|}{ Tuff } \\
\hline Chalk or Limestone & 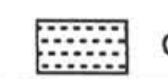 & Clay or Claystone & & \multicolumn{2}{|l|}{ Basalt } \\
\hline
\end{tabular}

Figure 2. Distribution of siliceous rocks recovered during Leg 129 by site, age, and associated lithologies. 

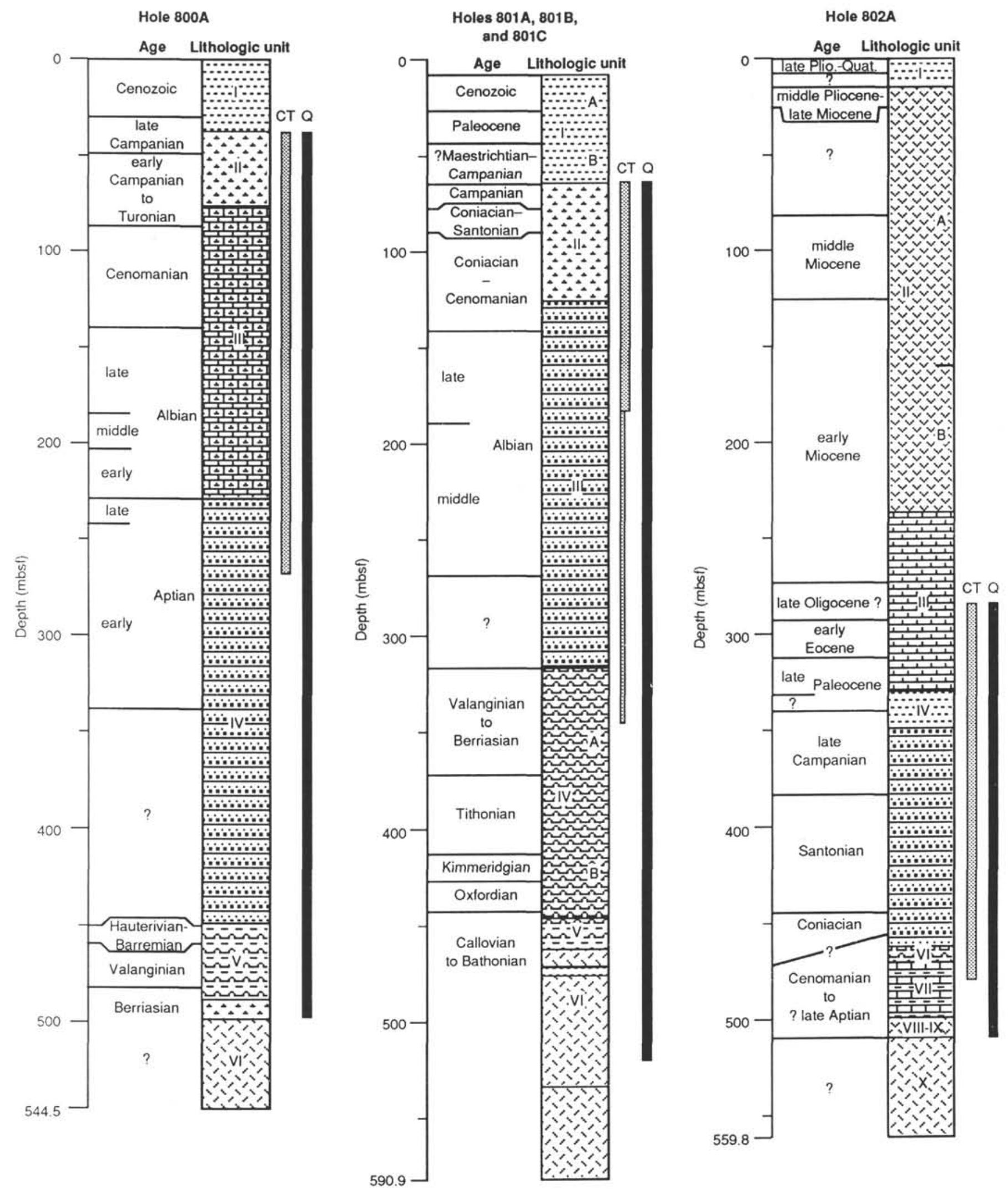

Figure 3. Stratigraphy of Leg 129 Sites 800, 801, and 802. Lithologic symbols are the same as in Figure 2. Depth ranges of opal-CT (CT) and diagenetic quartz (Q) were determined by XRD and petrographic examination. Thinner opal-CT bar below $184 \mathrm{mbsf}$ at Site 801 indicates opal-CT $\leq 2 \%$. 
Opal-C is well ordered to slightly disordered $\alpha$-cristobalite, showing only slight line broadening from true $\alpha$-cristobalite in X-ray diffractograms. Diagenetic quartz can be microcrystalline (1-20 micro-meters, or $\mu \mathrm{m}$, in diameter), cryptocrystalline $(<1 \mu \mathrm{m})$ or chalcedonic (petrographically fibrous) (Folk and Pittman, 1971; Keene, 1975).

\section{METHODS}

\section{Petrography and X-ray Diffraction}

We employed polarized light microscopy, scanning electron microscopy (SEM), using both secondary and backscattered images (BSEM), and energy dispersive X-ray spectroscopy (EDX) in our petrographic study.

$\mathrm{X}$-ray diffraction (XRD) analysis was performed with a Siemens D500 diffractometer with a copper anode, Soller slit and monochromator, operated at $45 \mathrm{kV}$ and $30 \mathrm{~mA}$. Diffractograms of powdered samples (ground to $<63 \mu \mathrm{m}$ ) were analyzed for the integrated intensities of key peaks, which were compared to experimentally derived mineral intensity factors to quantify the proportions of the various component phases.

\section{Oxygen Isotopic Sample Preparation and Analysis}

The siliceous rocks recovered during Leg 129 commonly contain mixed silica phases (opal-CT and diagenetic quartz), and are locally rich in clay minerals, zeolites, feldspars, and Fe- or Mn-oxides. All prospective $\mathrm{O}$-isotope samples were first analyzed for mineralogy and phase distribution by XRD and thin-section petrography. Mineral composition determined by XRD underestimates the abundance of visually-detectable, X-ray amorphous iron and manganese oxide/ hydroxides. In order to obtain meaningful O-isotopic values for the individual silica phases, we removed $\mathrm{Fe} / \mathrm{Mn}$-oxides, carbonates, and, in some cases, opal-CT with a modified version of the cleaning and separation method of Pisciotto (1981a), implemented as follows:

Only samples free of detrital quartz and feldspar were selected for $\mathrm{O}$-isotopic analysis. Most samples contained less than 2\% clay minerals; however, one radiolarite contained $6 \%$ clay, and two analyzed volcaniclastic-siliceous samples contained $16 \%$ clay.

All samples were ground to $<125 \mu \mathrm{m}$ and pretreated with $3 \mathrm{~N} \mathrm{HCl}$ to remove carbonates and with sodium hydrosulfite $\left(\mathrm{Na}_{2} \mathrm{~S}_{2} \mathrm{O}_{4}\right)$ to dissolve Fe- and $\mathrm{Mn}$-oxides. The proportion of opal-CT to diagenetic quartz was determined by XRD. If diagenetic silica consisted of mostly one phase $(>90 \%)$, we proceeded with oxygen extraction using methods similar to those of Clayton and Mayeda (1963). Loosely bound and adsorbed water was removed, however, by initial reaction with $\mathrm{BrF}_{5}$ and we attempted to remove structural water and hydroxyl groups from opal-CT by a 3-min reaction with gaseous $\mathrm{BrF}_{5}$ at temperatures slightly above $0^{\circ} \mathrm{C}$, prior to overnight reaction at $650^{\circ} \mathrm{C}$. Oxygen was converted to $\mathrm{CO}_{2}$ by platinum-catalyzed reaction with hot spectrographic carbon and isotopically analyzed with a VG Prism mass spectrometer. Where the sample contained a combination of opal-CT and diagenetic quartz, the sample was split, and we removed opal-CT from one split by boiling in $0.5 \mathrm{~N}$ sodium hydroxide $(\mathrm{NaOH})$, then proceeded with isotopic analysis of both samples to obtain $\delta^{18} \mathrm{O}_{\text {opal-CT + quartz }}$ and $\delta^{18} \mathrm{O}_{\text {quartz }}$ (see Pisciotto, 1981a). The $\delta^{18} \mathrm{O}_{\text {opal-CT }}$ can be calculated with the expression of Pisciotto (1981a):

$$
\delta^{18} \mathrm{O}_{\text {opal-CT }}=\frac{\delta^{18} \mathrm{O}_{\text {opal-CT }+ \text { quartz }}-\left(\text { wt } \% \text { quartz } \cdot \delta^{18} \mathrm{O}_{\text {quartz }}\right)}{\text { wt } \% \text { opal }-\mathrm{CT}}
$$

Oxygen isotope compositions are reported in the standard $\delta$-notation, where the $\delta^{18} \mathrm{O}$ value is the per mil deviation in ${ }^{18} \mathrm{O} /{ }^{16} \mathrm{O}$ with respect to Vienna Standard Mean Ocean Water (V-SMOW) (O'Neil, 1986). Twenty-one of 29 analyses were made in duplicate or triplicate, with an average standard deviation of $0.29 \%$. The four drilled mi- crosamples were too small for the described pretreatment or for repeated measurements.

\section{X-RAY DIFFRACTION RESULTS}

Eighty-eight samples of chert, porcellanite, radiolarite, chalk, limestone, and siliceous claystone were quantitatively analyzed by XRD for mineralogy (Table 1). Most are whole-rock samples, but several were subsampled to compare compositions across diagenetic and lithologic boundaries. The following general compositions were noted:

1. All analyzed siliceous rocks are composed principally of opal$\mathrm{CT}$, diagenetic quartz, or a mixture of both.

2. Analyzed siliceous rocks commonly contain minor to moderate amounts of clay minerals (chiefly smectite), calcite, zeolites (chiefly clinoptilolite), and iron/manganese oxide/hydroxides.

3. Few analyzed samples contain opal-C, amphibole, feldspars, or dolomite.

The stratigraphic distribution of opal-CT and diagenetic quartz varies at the three sites of Leg 129 (Fig. 3):

1. At Site 800 , the shallowest occurrence of both opal-CT and quartz is at 40 mbsf in Campanian bedded radiolarian porcellanite and chert; the deepest occurrence of opal-CT is at $268 \mathrm{mbsf}$ in lower Aptian radiolarian porcellanite interbedded with volcaniclastic turbidites.

2. At Site 801 , the shallowest opal-CT and quartz occur simultaneously at 64 mbsf in Campanian-Maestrichtian bedded radiolarian porcellanite and chert; opal-CT becomes volumetrically insignificant $(\leq 2 \%)$ at $184 \mathrm{mbsf}$ in middle Albian radiolarian porcellanite interbedded with volcaniclastic turbidites, and is absent below $347 \mathrm{mbsf}$ in Berriasian-Valanginian radiolarite.

3. The stratigraphic section of Site 802 is remarkable for its thick Tertiary sequence (Shipboard Scientific Party, 1990). Rapid accumulation of sediments at Site 802 depressed the silica phase boundaries to deeper stratigraphic levels (yet into younger sediments) than at Sites 800 and 801 . The shallowest opal-CT and diagenetic quartz at Site 802 occur together at 284-285 mbsf in upper Oligocene/lower Miocene nannofossil chalk, whereas the deepest incidence of opal-CT is at $479 \mathrm{mbsf}$ in Cenomanian limestone.

\section{Opal-CT d $\mathrm{d}_{101}$-spacing}

Previous XRD studies of the diagenesis of biosiliceous sediments have noted a progressive crystallographic ordering of the opal-CT d $\mathrm{d}_{01}$ spacing with burial depth from about 4.12 to 4.04 angstroms $(\AA)$ (Murata and Nakata, 1974; Murata and Larson, 1975; Hein et al., 1978; Hein et al., 1981; Pisciotto, 1981a). We find, in contrast, only very rudimentary trends toward smaller $d_{101}$ values with depth and age (Fig. 4). Part of the scatter in our data is due to different opal-CT d $d_{101}$ values for adjacent samples across diagenetic or stratigraphic boundaries. Differences in opal-CT $\mathrm{d}_{101}$ spacing between samples at the same depth reflect the effects of compositional variation in the primary sediments on the rates and timing of opal-CT precipitation, as well as on the degree of ordering when first precipitated (Isaacs, 1982). For instance, opal-CT in a burrow filling can have different $\mathrm{d}_{101}$ spacing than in the surrounding sediments, or likewise, siliceous samples with different clay contents, from just above and below a lithologic boundary, will commonly have distinct $\mathrm{d}_{101}$ values.

\section{CLASSIFICATION OF SILICEOUS ROCKS}

Diagenetic siliceous rocks recovered during Leg 129 can be classified according to inferred processes of chertification or lith- 


\begin{tabular}{|c|c|c|c|c|c|c|c|c|c|c|c|c|c|c|c|}
\hline $\begin{array}{l}\text { Core, section, } \\
\text { interval (cm) }\end{array}$ & $\begin{array}{l}\text { Depth } \\
\text { (mbsf) }\end{array}$ & Lithology & Type & Quartz & Opal-CT & Opal-C & $\begin{array}{c}\text { Clay } \\
\text { minerals }\end{array}$ & Calcite & Dolomite & Clinoptilolite & K-spar & Plagioclase & Amphibole & Hematite & Goethite \\
\hline \multicolumn{16}{|l|}{ 129-800A- } \\
\hline $6 \mathrm{R}-1,53-55$ & 40 & Radiolarian chert and porcellanite & B & 25 & 75 & & tr & & & & & & & & \\
\hline $8 \mathrm{R}-1,28-33$ & 59 & Radiolarian porcellanite & B & 13 & 87 & & & & & & & & & & \\
\hline $8 \mathrm{R}-1,28-33$ & 59 & Pink-orange oxide-free porcellanite lens & B & 19 & 81 & & & & & & & & & & \\
\hline "11R-1, 13-20 & 88 & Radiolarian chert & CR & 66 & 34 & & & & & & tr & & & & \\
\hline${ }^{b} 11 R-1,13-20$ & 88 & Calcareous porcellanite/siliceous limestone & CR & 28 & 35 & & & 38 & & & 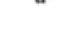 & & & & \\
\hline${ }^{\mathrm{a}} 12 \mathrm{R}-1,25-29$ & 98 & Cherty radiolarian porcellanite & CR & 23 & 77 & & & & & & & & & & \\
\hline$b_{12 R-1,25-29}$ & 98 & Calcareous porcellanite & $\mathrm{CR}$ & 18 & 56 & & & 26 & & & & & & & \\
\hline a $13 R-1,42-45$ & 107 & Radiolarian chert & $\mathrm{CR}$ & 100 & & & & & & & & & & & \\
\hline b $13 \mathrm{R}-1,42-45$ & 107 & Radiolarian chert & $\mathrm{CR}$ & 98 & 2 & & & & & & & & & & \\
\hline${ }^{\prime} 13 \mathrm{R}-1,42-45$ & 107 & Radiolarian siliceous limestone & $\mathrm{CR}$ & 27 & 44 & & & 29 & & & & & & & \\
\hline $14 \mathrm{R}-1,22-25$ & 116 & Radiolarian chert & $\mathrm{CR}$ & 96 & & & 2 & 2 & & & & & & & \\
\hline $16 \mathrm{R}-1,1-3$ & 135 & Radiolarian chert & $\mathrm{CR}$ & 98 & & & 2 & & & & & & & & \\
\hline $17 \mathrm{R}-1,76-79$ & 145 & Radiolarian chert & CR & 90 & 6 & & 2 & 2 & & & & & & & \\
\hline $18 \mathrm{R}-2,6-8$ & 155 & Radiolarian chert & CR & 96 & & & 2 & 2 & & & & & & & \\
\hline "19R-1, 80-84 & 164 & Radiolarian siliceous limestone & $\mathrm{CR}$ & 25 & 22 & & $i$ & 51 & & & & & & & \\
\hline b $19 \mathrm{R}-1,80-84$ & 164 & Radiolarian chert & CR & 94 & & & & 6 & & & & & & & \\
\hline $20 \mathrm{R}-1,23-28$ & 173 & Gray chert & CR & 87 & & & 8 & 5 & & & & & & & \\
\hline $21 \mathrm{R}-1,88-98$ & 182 & Radiolarian siliceous limestone and chert & CR & 17 & 34 & & & 49 & & & & & & & \\
\hline $22 \mathrm{R}-1,15-18$ & 191 & Radiolarian limestone and chert lamination & $\mathrm{CR}$ & 17 & 26 & & & 57 & & & & & & & \\
\hline $23 \mathrm{R}-1,29-32$ & 201 & Radiolarian porcellanite & CR & 53 & 41 & 6 & & & & & & & & & \\
\hline${ }^{2} 23 R-1,29-32$ & 201 & Radiolarian chert & CR & 100 & & & & & & & & & & & \\
\hline $30 \mathrm{R}-1,22-24$ & 266 & Radiolarian siliceous volcaniclastic claystone & $\mathrm{v}$ & 13 & 39 & & 15 & & & 33 & & & & & \\
\hline $30 \mathrm{R}-2,1-3$ & 267 & Radiolarian porcellanite & V/B & 27 & 57 & & 16 & & & & & & & & \\
\hline $43 \mathrm{R}-1,125-128$ & 376 & Radiolarian porcellanite & $\mathrm{V} / \mathrm{B}$ & 84 & & & 16 & & & & & & & & \\
\hline $55 \mathrm{R}-2,120-126$ & 482 & Clayey radiolarite & B & 70 & & & 30 & & & & tr & tr & & & \\
\hline $58 \mathrm{R}-1,33-36$ & 508 & Radiolarian porcellanite & $T / B$ & 100 & & & & & & & & & & & \\
\hline \multicolumn{16}{|l|}{ 129-801A- } \\
\hline $7 R-4,40-44$ & 64 & Cherty radiolarian porcellanite & B & 27 & 53 & & 20 & & & & & & & & \\
\hline $8 R-1,26-29$ & 69 & Radiolarian porcellanite & B & & & & & & & & & & & & \\
\hline $10 \mathrm{R}-1,7-10$ & 88 & Radiolarian porcellanite & B & $\mathbf{P}$ & $\mathrm{P}$ & & & & & & & & & & \\
\hline${ }^{\mathrm{a}} 12 \mathrm{R}-1,17-19$ & 107 & Radiolarian chert & B & 18 & 84 & & & & & & & & & & \\
\hline${ }^{6} 12 \mathrm{R}-1,17-19$ & 107 & Radiolarian porcellanite & B & 4 & 96 & & & & & & & & & & \\
\hline $13 \mathrm{R}-1,14-16$ & 117 & Calcareous radiolarian porcellanite & $\mathrm{B} / \mathrm{CR}$ & 14 & 61 & & tr & 25 & & & & & & & \\
\hline $17 \mathrm{R}-1,52-54$ & 156 & Siliceous volcaniclastic claystone & $\mathrm{v}$ & 4 & 38 & & 5 & & & 53 & & & & & \\
\hline $20 \mathrm{R}-1,2-4$ & 184 & Radiolarian volcaniclastic porcellanite & $\mathrm{B} / \mathrm{V}$ & 4 & 54 & & 26 & 5 & & 11 & & & & & \\
\hline \multicolumn{16}{|l|}{ 129-801B- } \\
\hline $6 \mathrm{R}-4,83-85$ & 247 & Radiolarian volcaniclastic chert & $\mathrm{v}$ & 80 & & & 8 & 12 & & & & & & & \\
\hline$=11 \mathrm{R}-1,8-10$ & 290 & Clayey radiolarite & $\mathrm{B} / \mathrm{V}$ & 32 & & 5 & & 7 & & 31 & & & 18 & 7 & \\
\hline${ }^{b} 11 \mathrm{R}-1,8-10$ & 290 & Radiolarian porcellanite & $\mathrm{B} / \mathrm{V}$ & 58 & & 2 & & 2 & & 22 & & & 6 & 10 & \\
\hline $12 \mathrm{R}-1,61-62$ & 300 & Radiolarian volcaniclastic claystone/porcellanite & $\mathrm{v}$ & 58 & 1 & & 41 & & & & & & & & \\
\hline $12 R-1,61-62$ & 300 & Radiolarian volcaniclastic claystone/porcellanite & $\mathrm{v}$ & 58 & & & 42 & & & & & & & & \\
\hline $13 \mathrm{R}-1,24-26$ & 309 & $\begin{array}{l}\text { Radiolarian volcaniclastic claystone } \\
\text { Rent }\end{array}$ & v & 14 & 2 & & 45 & 3 & & 36 & & & & & \\
\hline${ }^{2} 16 \mathrm{R}-1,27-31$ & 337 & Dark brown radiolarian chert & B & 93 & & & 7 & & & & & & & & \\
\hline b $16 \mathrm{R}-1,27-31$ & 337 & Reddish brown cherty porcellanite & B & 73 & & & 27 & & & & & & & & \\
\hline $17 \mathrm{R}-1,9-12$ & 347 & Radiolarite & B & 48 & & 12 & 40 & & & & & & & & \\
\hline $217 \mathrm{R}-1,29-33$ & 347 & Radiolarian porcellanite nodule rim & B & 80 & & 20 & & & & & & & & & \\
\hline b $17 \mathrm{R}-1,29-33$ & 347 & Radiolarian chert nodule center & B & 92 & 1 & & 6 & & & & & & & & \\
\hline $18 \mathrm{R}-1,41-46$ & 356 & Radiolarian chert & B & $\mathrm{P}$ & & & $\mathrm{P}$ & & & & & & & & \\
\hline $20 \mathrm{R}-1,1-3$ & 375 & Radiolarian chert and radiolarite & B & P & & & P & & & & & & & & \\
\hline $23 \mathrm{R}-\mathrm{CC}, 1-4$ & 396 & Radiolarian chert nodule & B & 92 & & & 5 & & 3 & & tr & & & & \\
\hline $24 \mathrm{R}-1,28-31$ & 401 & Radiolarian chert & B & 100 & & & tr & & & & & & & & \\
\hline $25 \mathrm{R}-1,67-70$ & 406 & Radiolarian chert nodule (and radiolarite) & B & 98 & & & 2 & & & & & & & & \\
\hline $27 \mathrm{R}-1,107-109$ & 416 & Radiolarian cherty porcellanite & B & 100 & & & $\operatorname{tr}$ & & & & & & & & \\
\hline $28 \mathrm{R}-1,12-14$ & 420 & Radiolarian cherty porcellanite & B & 98 & & & 2 & & & & & & & & \\
\hline
\end{tabular}


Table 1 (continued).

\begin{tabular}{|c|c|c|c|c|c|c|c|c|c|c|c|c|c|c|c|}
\hline $\begin{array}{l}\text { Core, section, } \\
\text { interval }(\mathrm{cm})\end{array}$ & $\begin{array}{l}\text { Depth } \\
\text { (mbsf) }\end{array}$ & Lithology & Type & Quartz & Opal-CT & Opal-C & $\begin{array}{c}\text { Clay } \\
\text { minerals }\end{array}$ & Calcite & Dolomite & Clinoptilolite & K-spar & Plagioclase & Amphibole & Hematite & Goethite \\
\hline $29 \mathrm{R}-1,11-13$ & 424 & Radiolarian chert (red) & B & 99 & & & 1 & & & & & & & & \\
\hline $30 \mathrm{R}-1,14-16$ & 429 & Radiolarian chert & B & 98 & & & 2 & & & & & & & & \\
\hline $31 \mathrm{R}-1,22-23$ & 434 & Radiolarian chert (reddish brown) & B & 98 & & & 2 & & & & tr & & & & \\
\hline $34 \mathrm{R}-1,3-5$ & 448 & Radiolarian-bearing volcaniclastic porcellanite & & 57 & & & & 8 & & & & & 26 & 8 & \\
\hline $37 \mathrm{R}-1,24-26$ & 462 & Interflow chert crackle breccia & $\mathbf{T}$ & 100 & & & & & & & & & & & \\
\hline 4IR-1, 3-5 & 483 & Interflow chert crackle breccia & $\mathbf{T}$ & 100 & & & & & & & tr & & & & \\
\hline \multicolumn{16}{|l|}{ 129-801C- } \\
\hline $4 R-1,69-71$ & 522 & Quartzified hydrothermal deposit & & $\mathbf{P}$ & & & & & & & & & & & $\mathbf{P}$ \\
\hline \multicolumn{16}{|l|}{ 129-802A- } \\
\hline $29 \mathrm{R}-2,5-7$ & 256 & Clayey nannofossil chalk & & & & & & 71 & & 29 & & & & & \\
\hline $29 \mathrm{R}-\mathrm{CC}, 22-26$ & 258 & Nannofossil chalk & & tr & & & & 100 & & & & & & & \\
\hline $30 \mathrm{R}-1,43-46$ & 265 & Nannofossil chalk & & & & & tr & 100 & & tr & & & & & \\
\hline $31 \mathrm{R}-1,26-29$ & 274 & Clayey nannofossil chalk & & & & & 2 & 64 & & 34 & & & & & \\
\hline $31 \mathrm{R}-2,17-20$ & 275 & Nannofossil chalk & & & & & & 100 & & & & & & & \\
\hline $32 \mathrm{R}-2,79-81$ & 286 & Foraminiferal chalk & CR & 2 & 43 & & 11 & 37 & & 7 & & & & & \\
\hline $32 R-3,5-7$ & 287 & Volcaniclastic foraminiferal chalk & CR & 6 & 32 & & & 42 & & & & & 16 & 5 & \\
\hline $33 \mathrm{R}-1,54-56$ & 293 & Nannofossil chalk & & & & & & 97 & & 3 & & & & & \\
\hline $34 R-1,18-21$ & 302 & Nannofossil chalk & & & & & & 99 & & 1 & & & & & \\
\hline $34 \mathrm{R}-1,75-78$ & 303 & Nannofossil chalk & & & & & & 100 & & tr & & & & & \\
\hline $34 \mathrm{R}-1,135-137$ & 304 & Chert within chalk & CR & 100 & & & tr & & & & & & & & \\
\hline $35 \mathrm{R}-1,12-14$ & 312 & Calcareous porcellanite & CR & 9 & 80 & & & 11 & & & & & & & \\
\hline $35 \mathrm{R}-1,26-29$ & 312 & Siliceous chalk & CR & 3 & 57 & & & 40 & & & & & & & \\
\hline $35 R-1,52-56$ & 312 & Nannofossil chalk & & tr & & & & 98 & & 2 & & & & & \\
\hline $35 R-C C, 8-11$ & 312 & Chert & CR & 94 & & & 6 & & & & tr & & & & \\
\hline $36 \mathrm{R}-1,60-63$ & 321 & Foraminiferal chalk & & & & & & 100 & & tr & & & & & \\
\hline $36 R-1,67-69$ & 321 & Chert & CR & 81 & & & 19 & & & & & & & & \\
\hline '36R-1. 67-69 & 321 & Calcareous porcellanite & CR & 39 & 30 & & 20 & 11 & & & & & & & \\
\hline $39 \mathrm{R}-1,37-39$ & 349 & Radiolarian porcellanite & B & 4 & 92 & & tr & & & 4 & & & & & \\
\hline 4IR-1, 13-14 & 366 & Volcaniclastic claystone & & & & & 78 & & & 22 & & & & & \\
\hline $42 \mathrm{R}-1,25-27$ & 373 & Calcareous volcaniclastic porcellanite & $\mathrm{v}$ & to & 70 & & 13 & 6 & & 10 & & & & & \\
\hline $43 R-1,42-44$ & 383 & Volcaniclastic porcellanite to claystone & $\mathrm{v}$ & 3 & 45 & & 40 & & & 12 & & & & & \\
\hline $52 R-3,28-31$ & 463 & Radiolarite & B & 67 & 15 & & 17 & & & & & & & & \\
\hline $52 R-3,90-93$ & 464 & Radiolarian porcellanite & B & 3 & 48 & & 42 & & & 7 & & & & & \\
\hline $53 R-2,91-93$ & 472 & Clayey volcaniclastic nannofossil chalk & V/CR & 20 & & & 31 & 27 & & 20 & tr & to & & & \\
\hline "54R-1, 87-89 & 479 & Siliceous nannofossil chalk & CR & 26 & 20 & & & 54 & & & & & & & \\
\hline${ }^{6} 54 R-1,87-89$ & 479 & Chert & CR & 100 & & & & & & & & & & & \\
\hline $55 \mathrm{R}-1.96-98$ & 489 & Radiolarian siliceous limestone & & 54 & & & tr & 46 & & & & & & & \\
\hline
\end{tabular}

Notes: Siliceous rock types: $\mathrm{CR}=$ carbonate replacement; $\mathrm{B}=$ bedded (clayey-siliceous): $\mathrm{V}=$ volcaniclastic/volcanic-related: $\mathrm{T}=$ thermal. $\mathrm{P}=$ principle component $(\geq 25 \%)$; $\mathrm{tr}=$ trace $\operatorname{component}(\mathbf{1}$ 1\%).

b., CLithologic subsamples. 

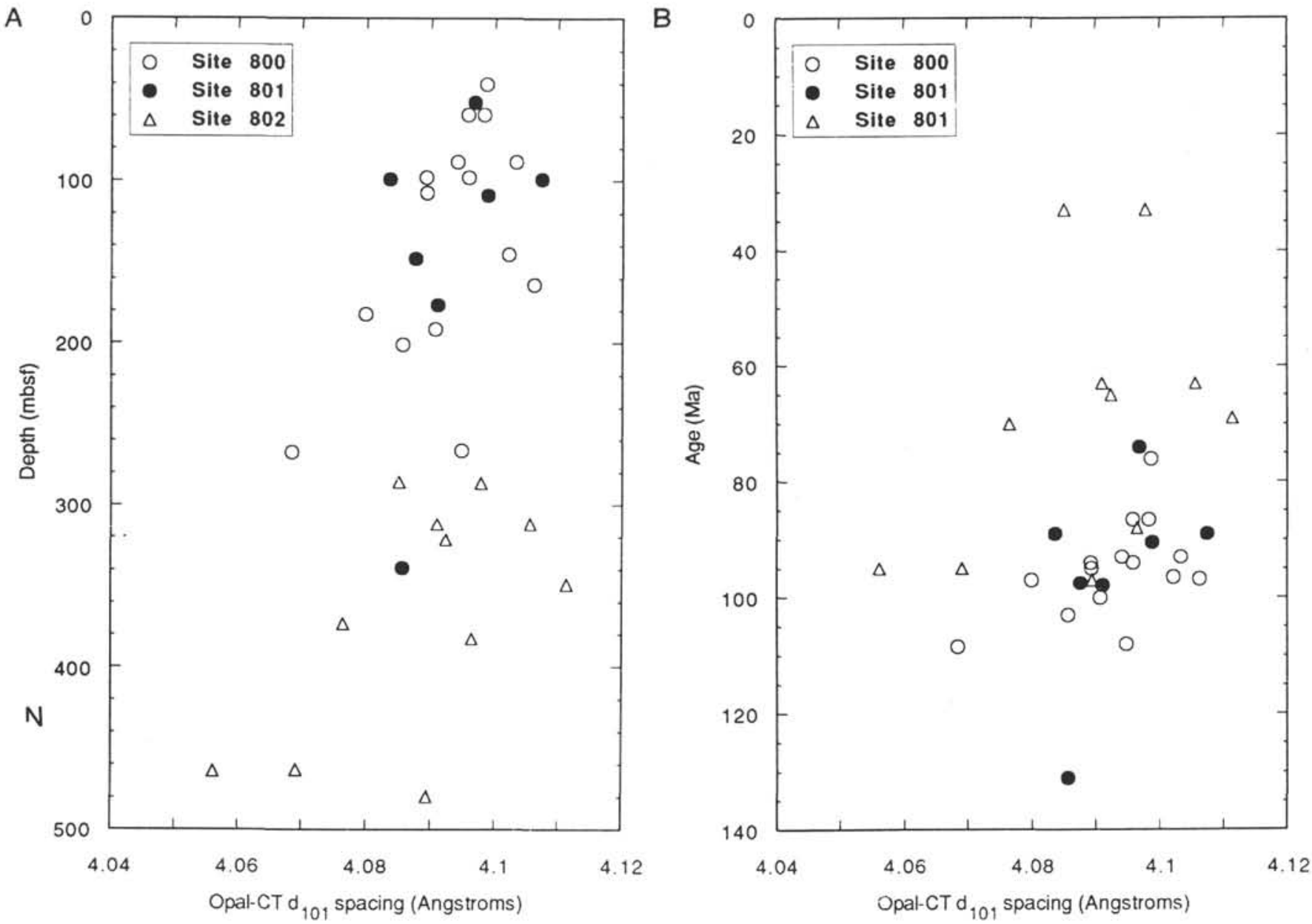

Figure 4. Distribution of opal-CT d $\mathrm{d}_{101}$ spacing of samples from Sites 800,801 , and 802 with respect to depth below seafloor (A) and age (B).

ologic association, in addition to primary textural designations such as chert, porcellanite, or radiolarite. Heath and Moberly (1971) classified deep-sea siliceous diagenetic rocks as nodular (carbonatereplacement) chert or bedded (associated with clayey or biosiliceous sediments) chert. Although many more varieties of diagenetic siliceous rocks can be recognized depending on the criteria chosen (von Rad and Rösch, 1974), the differences are often gradational rather than clear, end-member distinctions. Below, Leg 129 samples are classified using Heath and Moberly's (1971) carbonate-replacement and bedded chert categories, as well as two other genetic (thermal chert) and environmental (volcanic-related chert) categories.

\section{Carbonate-replacement Chert and Porcellanite}

Leg 129 recovered carbonate-replacement cherts and porcellanites of Cretaceous age (Albian to Campanian) at Site 800, and of Tertiary (late Paleocene to early Miocene) and Cenomanian age at Site 802 (Fig. 3). Lower Miocene-upper Oligocene opal-CT porcellanite and lower Eocene quartz chert of Site 802 (Unit II) formed in foraminifer and nannofossil chalk, and are the youngest diagenetic siliceous rocks recovered during Leg 129 (Fig. 2). Carbonatereplacement chert forms nodules and laminations, chiefly at locations of burrows and foraminifer-rich packstones, a distribution noted by previous workers at other drilling sites (PI. 1, Fig. 1) (Lancelot, 1973; Keene, 1975, 1976). Many nodular cherts recovered during Leg 129 display a characteristic, sharp three-part zonation of quartz chert, opalCT and quartz porcellanite, and siliceous chalk or limestone (PI. 1,
Fig. 2) that is common in flints worldwide (Pl. 1, Fig. 3) (Wise and Weaver, 1974; Riech and von Rad, 1979).

Detailed examination of chertification fronts by a combination of optical and backscattered electron microscopy gives a new view of this diagenetic boundary. BSEM distinguishes between minerals or grains with different atomic densities, reflecting both their atomic number (elemental composition) and density; opal-CT and quartz can be clearly distinguished at high magnifications (PI. 1, Fig. 4), even in densely packed masses that would not be resolved with a SEM operated in the normal, secondary electron mode. Although the precise gray value in each micrograph differs with operational settings of the electron microscope, opal-CT is typically dark gray (low atomic density), microcrystalline or chalcedonic quartz is medium gray, and calcite is light gray or white (higher atomic number). Variations in porosity and water content can be identified in a single mineral, such as the late stage, porous perimeters of chalcedony spherules vs. the densely packed interiors (Pl. 1, Figs. 5 and 6).

Within the transition zone between a calcareous host and quartz chert, foraminiferal tests and other calcareous bioclasts were first cemented and partially filled by opal-CT lepispheres while undergoing partial dissolution (Pl. 1, Fig. 4). Length-fast chalcedony spherules then nucleated on and grew outward from the opal-CT lepispheres (Pl. 1, Fig. 5). Chalcedony continued to grow outward radially as it filled voids and replaced calcareous bioclasts. Biogenic calcium carbonate, mobilized by dissolution during silica replacement, concurrently reprecipitated as sparite in remaining open spaces within the transition zone surrounding the growing quartz chert nodule (Pl. 1, Fig. 6). 
Fragments of monocrystalline calcite or patches of partially silicified chalk are locally preserved in the dense, microcrystalline quartz chert, suggesting encapsulation and isolation from further addition of silica or removal of calcite (PI. 1, Fig. 7).

\section{Bedded Chert and Porcellanite}

Bedded cherts and porcellanites were recovered from Middle Jurassic to Late Cretaceous strata. Most are not particularly well bedded, but display a more homogeneous and extensive chertification than do carbonate-replacement (nodular) cherts, at least within the dimensions of a 10-cm-wide core (Pl. 2, Fig. 1). At Sites 800 and 801, bedded chert and porcellanite form by the silicification of radiolarite or the silicification and replacement of radiolarian-bearing clay, as shown by the presence of abundant radiolarian tests, both replaced and filled by diagenetic silica (Pl. 2, Fig. 2). Most chert contacts with radiolarite, porcellanite, or claystone are discordant to bedding, and many crosscut undeformed laminations or separate zones that are differentially compacted (Pl. 2, Fig. 3). Thus, the concentration of silica in chert beds and nodules is a diagenetic process that can occur during early and late stages of burial.

The Upper Cretaceous brown chert and porcellanite units penetrated at Sites 800 and 801 (Unit II) appear similar to undisturbed samples of the overlying and intercalated pelagic clay in terms of texture, color, and bioturbation. The chert and porcellanite, however, are well lithified and principally composed of opal-CT with 5\%-30\% chalcedony-filled radiolarians, whereas the pelagic clay is mostly clay minerals, zeolites, and $\mathrm{Fe} / \mathrm{Mn}$-oxide/hydroxides, and lacks radiolarians. Radiolarian-rich clay occurs only in a narrow interval directly overlying the lithologic contact with chert (PI. 2, Fig. 4). Similarities in fabric and color between the siliceous rocks and overlying pelagic clay deposits suggest that they both were deposited in similar environments and may have had similar primary compositions at the seafloor. The faster sediment accumulation rates of Unit II ( $3 \mathrm{~m} / \mathrm{m} . \mathrm{y}$. vs. $<1$ $\mathrm{m} / \mathrm{m}$.y. for Unit I; Lancelot, Larson, et al., 1990) contributed to the burial and preservation of siliceous microfossils and their later availability as a source of diagenetic silica. Up to some threshold, increased rates of radiolarian surface productivity are not recorded in the sediments due to dissolution in the water column and at the seafloor. This example suggests that a minimum post-compaction sediment accumulation rate of $1-3 \mathrm{~m} / \mathrm{m}$.y. is required for the preservation of radiolarianrich deposits in an abyssal setting. The decreased sediment accumulation rate from the Late Cretaceous through the Cenozoic reflects the continued northerly movement of the Pigafetta Basin away from the high productivity equatorial divergence (Lancelot, Larson, et al., 1990).

Although most radiolarian tests and molds in the opal-CT chert and porcellanite are filled with length-fast chalcedony, some are filled with a homogeneous mixture of clay minerals, $\mathrm{Fe} / \mathrm{Mn}$-oxides and opal-CT (Pl. 2, Figs. 5 and 6). The composition of this filling is probably representative of the original sedimentary matrix, isolated in protected pockets prior to advanced silica diagenesis. If so, the original sediments contained more clay and $\mathrm{Fe} / \mathrm{Mn}$-oxide/hydroxides than are now preserved in the chert and porcellanite. The amount of clay minerals present in siliceous rocks is also reflected in the microtexture of diagenetic quartz. Clay mineral-rich porcellanites tend to have cryptocrystalline $(<1 \mu \mathrm{m}$ crystallite diameter) quartz matrices, whereas clay-poor cherts are typically composed of microcrystalline $(1-20 \mu \mathrm{m})$ quartz (Sample 129-801B-29R-1, 11-13 cm). Quartz crystallite size probably reflects the rate of transformation of opal-CT to quartz. The diagenetic transformation of smectite to illite with time or burial depth may be an accessory source of silica for chertification (Keene and Kastner, 1974).

\section{Thermal Chert and Porcellanite}

Thermal cherts are rocks that were silicified under abnormally high temperature conditions such as close proximity to volcanic sills or flows, or within hydrothermal systems. Temperature is the principle control of silica solubility and rates of dissolution and recrystallization; locations or events of atypically high temperatures can alter the usual sequence of silica burial diagenesis (see discussion in Kastner and Siever, 1983).

We recognize thermal cherts in core, outcrop, or thin section by a combination of the following criteria (thermal cherts are not uniquely identified by any single criterion):

1. Close stratigraphic proximity to volcanic sills or flows (e.g., Sample $129-800$ A-58R-1, $33-36 \mathrm{~cm}$ ).

2. Desiccation fracture texture in chert breccia from rapid dewatering associated with the intrusion of basalt sills (Davis, 1918; Bailey et al., 1964) (e.g., Sample 129-801B-37R-1, 24-26 cm; Pl. 3, Figs. 1 and 2).

3. Silicification of relatively uncompacted sediments compared to the degree of compaction expressed by superjacent strata (e.g., Sample 129-801B-39R-1, 27-32 cm, Pl. 3, Fig. 3).

4. Silicification and/or replacement of hydrothermal deposits (Sample 129-801C-4R-1, 69-71 cm, Pl. 3, Figs. 4 and 5).

5. Equant, coarse microcrystalline to megacrystalline $(10-30 \mu \mathrm{m}$ crystallite diameter) quartz texture (Sections $129-800 \mathrm{~A}-56 \mathrm{R}-1,8 \mathrm{~cm}$, through $-58 \mathrm{R}-1,36 \mathrm{~cm}, \mathrm{Pl} .3$, Fig. 6).

Thermal cherts and porcellanites formed by silicification of a variety of precursor sediments, including radiolarian ooze, pelagic clay, and metalliferous hydrothermal deposits.

\section{Volcanic-related Siliceous Rocks}

A few previous workers have argued that the deep-sea association of cristobalite, clinoptilolite, and montmorillonite suggest a volcanic origin for the silica in deep-sea cherts and porcellanites (Gibson and Towe, 1971). However, many researchers have documented the nearly ubiquitous association of biogenic silica with chert and porcellanite, the vast availability of biosilica in the ocean reservoir, and the absence of volcanic deposits associated with most deep-sea siliceous rocks (see reviews in Garrison, 1974; Wise and Weaver, 1974; Riech and von Rad, 1979; and Kastner, 1981). Furthermore, clinoptilolite has been shown to precipitate in the absence of volcanic deposits (Berger and von Rad, 1972; Hein et al., 1978; Kastner and Stonecipher, 1978).

Volcanic-related chert and porcellanite are interbedded or intermixed with volcanic material or volcaniclastic sediments and form by the silicification and/or replacement of mixed pelagic, biosiliceous and volcanogenic material. XRD shows $5 \%-45 \%$ (21\% average) clay minerals and $0 \%-53 \%$ (16\% average) clinoptilolite in analyzed volcanic-related siliceous rocks. Petrographic examination shows that radiolarians are mostly filled with coarse, euhedral clinoptilolite crystals, instead of opal-CT or chalcedony (Fig. 5A, B) and are replaced by clinoptilolite, opal-CT, or both (Fig. 5B, C). Sufficient concentrations of aluminum and potassium and a dissolved silica concentration below that of opal-CT saturation favors the precipitation of clinoptilolite over opal-CT (Riech and von Rad, 1979). Abundant clinoptilolite, in turn, forms only weakly cemented rocks (e.g., siliceous claystone or porcellanite). Low concentrations of silica in pore water may have been due to the alteration of volcanic glass and silica adsorption onto resulting smectite.

\section{BEDDING}

Mountain-belt ribbon radiolarian cherts exposed on land are characterized by the sharpness of their bedding and the extreme lithologic difference between beds of radiolarian chert and thin shale interbeds (partings). It is this feature of radiolarites that has not been observed in cores from the deep sea, giving rise to much debate on the origin of ribbon radiolarites (Jenkyns and Winterer, 1982; Hein and Karl, 1983). 
A

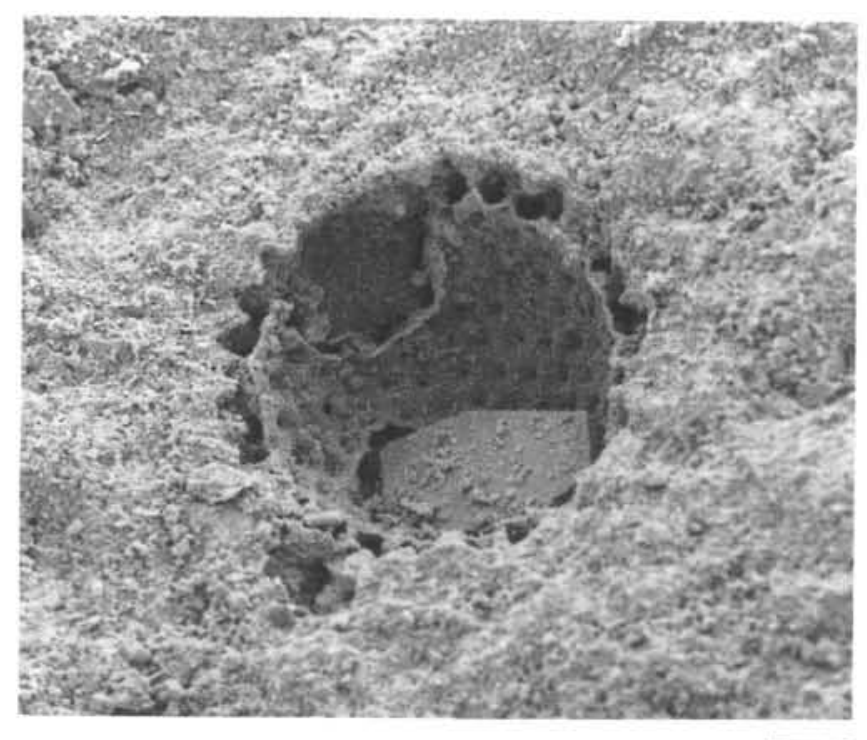

$25 \mu \mathrm{m}$

B

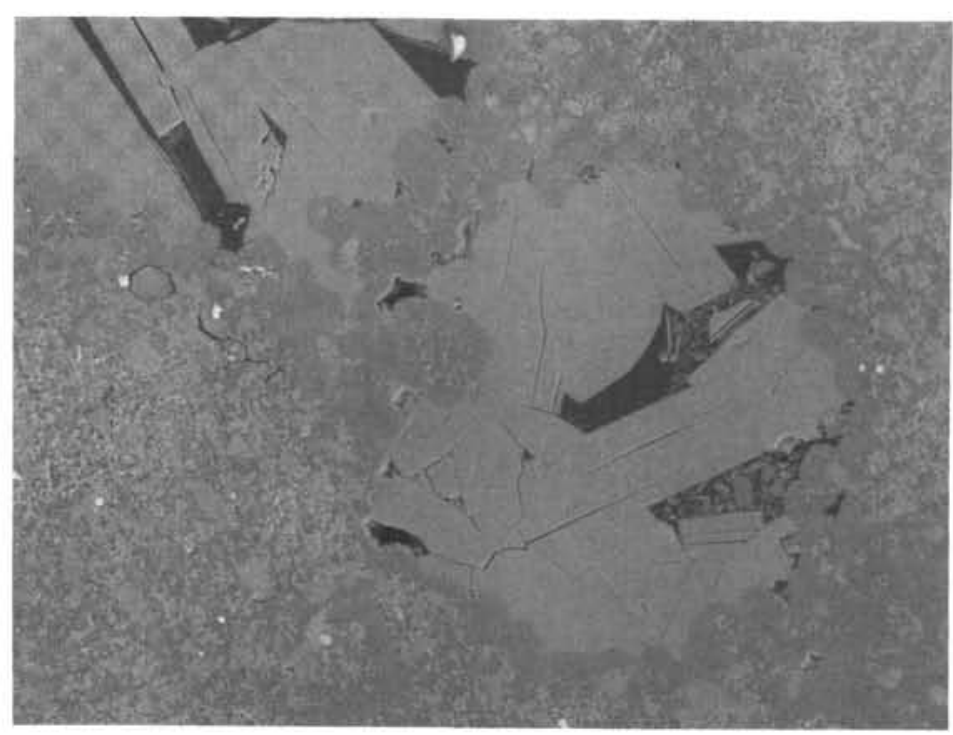

c

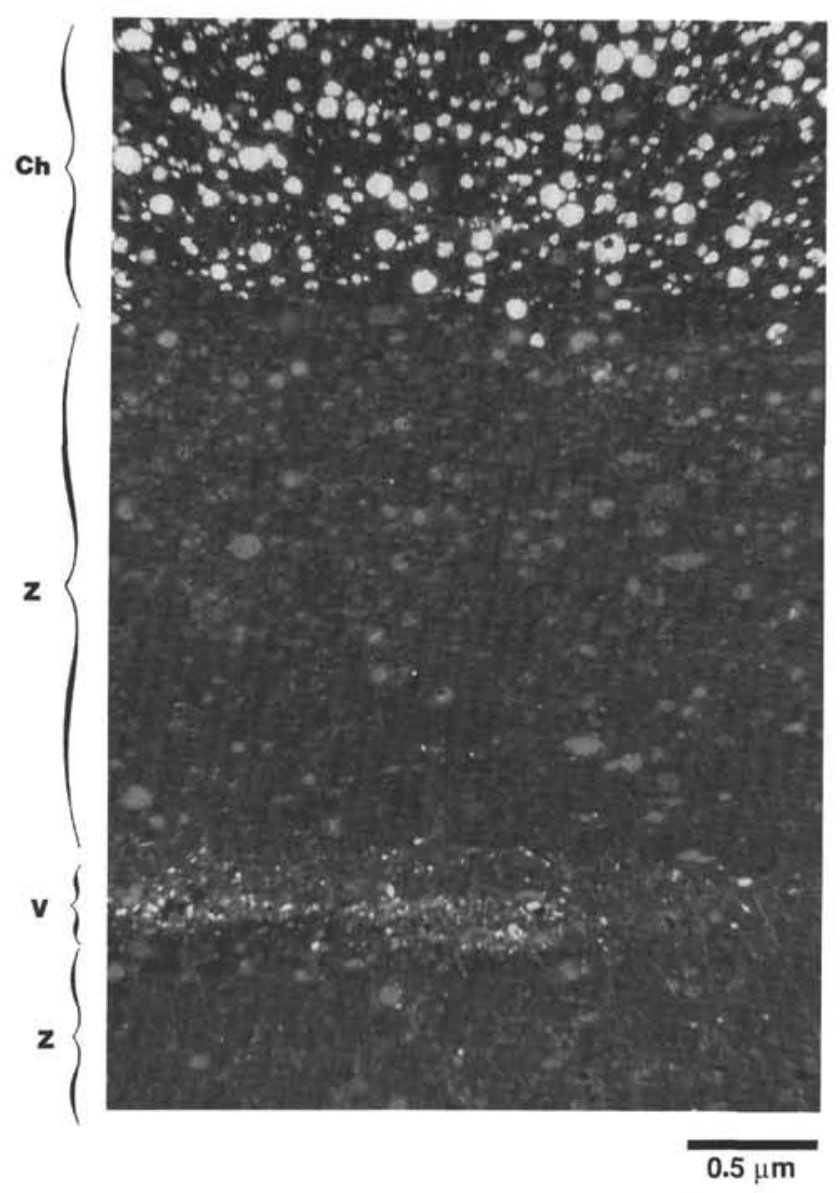

$25 \mu \mathrm{m}$

Figure 5. Volcaniclastic or volcanic-related siliceous rocks. A. SEM photomicrograph of radiolarian mold in volcanic-related porcellanite with euhedral clinoptilolite crystal. Note dissolution of radiolarian test; Lower Cretaceous, Sample 129-801B-11R-1, 8-10 cm. B. BSEM photomicrograph of radiolarians in volcanic-related porcellanite with euhedral clinoptilolite crystals. Radiolarians have been replaced by opal-CT lepispheres with near complete loss of detailed morphology. Matrix is composed of opal-CT, zeolites, and smectite; Lower Cretaceous, Sample 129-800A-30R-2, 19-21 cm. C. Photomicrograph of radiolarite overlying thin, volcaniclastic turbidite ( $\mathrm{V}$, bottom). Radiolarians near turbidite have been partially dissolved, compacted, and filled with zeolite crystals ( $\mathrm{Z}$ ). Radiolarians near top have been replaced and filled with chalcedony without obvious compaction (Ch); upper Aptian, Sample 129-800A-25R-2, 22-25 cm.

Leg 129 recovered some well-bedded radiolarites (e.g., Neocomian of Site 800 and parts of the Callovian through Valanginian of Site 801), but without the sharp lithologic contrast typical of ribbon cherts. The observed bedding was produced by a number of mechanisms, including radiolarian turbidites, variation in composition of pelagic sedimentation, and current sorting (Lancelot, Larson, et al., 1990). Beds of radiolarians, graded by size or by number, occur as turbidites, as primary variations in pelagic deposition, and also as a result of an upward increase in dissolution, perhaps caused by a stage of decreased surface water productivity and sedimentation rate. Well-bedded chert, shown by geophysical logs in poorly recovered Oxfordian-Kimmerid-gian strata of Hole 801B (see Molinie and Ogg; Ogg et al., this volume), probably reflects the silicification and concentration of silica in compositionally or texturally preferred layers of the original sedimentary deposits. Geochemical evidence supporting the diagenetic segregation and concentration of silica in other bedded cherts is given by the distribution of rare earth, major, and minor elements (Murray et al., 1990, 1992).

Most recovered samples of quartz and opal-CT cherts have obliqueto-bedding silicification boundaries and are poorly bedded. Heath and 
Moberly (1971) suggested that individual silicified layers of "bedded" chert recovered from the western Pacific during Deep Sea Drilling Program (DSDP) Leg 7, may extend laterally as little as tens of meters and are usually less than $10 \mathrm{~cm}$ thick. Similarly, most of the Leg 129 chert samples that were recovered with their host radiolarite still intact show a discordant contact, indicating that silicification (chertification) is not continuous along bedding, and not solely one of in-situ phase transformation along a stratigraphic horizon (cf. Isaacs, 1982), but is a process of localized silica addition. For the most part, dense chert forms lenses of silicified sediment, even within well-bedded radiolarites. Laterally extensive, continuously bedded chert may eventually develop from the coalescence of these lenses with continued bed-to-bed migration of silica into preferred horizons, although this may require some component of pressure solution with deep burial or tectonic loading during accretion to a continental margin (Brueckner et al., 1987).

\section{SOURCES OF SILICA AND RADIOLARIAN DIAGENESIS}

Nearly all siliceous rocks recovered during Leg 129 formed within radiolarian-rich primary sediments. Radiolarians provided most of the silica for lithification, although diatoms and sponge spicules cannot be excluded as contributors in some intervals. Even volcanic-related chert and porcellanite contain abundant radiolarian molds and casts, although filled with clinoptilolite instead of authigenic silica. Only some of the thermal cherts may have had important inorganic sources of silica. We examined the diagenesis of radiolarians to understand the relationship between their dissolution or replacement and chertification processes. We found radiolarian diagenesis to be complex and variable, and distinct even between adjacent radiolarians within the same sample. Depending on microenvironmental variations, individual radiolarian tests may have experienced any, but not necessarily all, of the following steps, in this generalized sequence:

1. Host sediment compacted around opal-A radiolarian tests or shored back by radiolarian spines.

2. Radiolarian tests filled in or remaining empty of primary sedimentary matrix (Pl. 4, Fig. 1).

3. Radiolarians compacted (crushed) or rigid (Pl. 4, Fig. 2).

4. Radiolarian tests coated by unidentified (organic?) opaque material.

5. Partial or complete dissolution of radiolarian tests (Fig. 5A).

6. Radiolarian molds filled by sparry calcite in predominantly calcareous sediments.

7. Opal-A tests replaced by opal-CT, preserving morphology, especially in calcareous-siliceous sediments (Pl. 4, Fig. 3).

8. Radiolarian tests filled partly or fully with opal-CT lepispheres (Pl. 4, Figs. 2, 3, and 5).

9. Radiolarian tests filled partly or fully with length-fast chalcedony (Pl. 4, Figs. 2-5).

10. Radiolarian tests replaced, or filled partly or fully with zeolite (chiefly clinoptilolite), particularly where associated with volcanogenic material (smectite, plagioclase, volcanic rock fragments) (Fig. 5A, B).

11. Replacement of opal-CT cement or opal-CT-replaced radiolarian tests with length-fast chalcedony or microcrystalline quartz (Pl. 5, Fig. 3).

12. Dissolution of opal-CT-replaced tests.

13. Recrystallization of fibrous chalcedony to microcrystalline quartz or megaquartz.

These observations share many features with the alteration sequence discussed in detail by Thurow (1988) for radiolarians of the North Atlantic.

\section{HOLE 802A PALEOGENE HIATUS: REQUIRED TIME FOR DEEP-SEA CHERTIFICATION OF CALCAREOUS SEDIMENTS}

Previous workers have suggested that about $40 \mathrm{~m}$.y. is required after deposition for initial silicification to occur in deep-sea sediments exposed to typical geothermal gradients (Keene, 1975, 1976; Riech and von Rad, 1979; Hein et al., 1981). We have the opportunity to test this hypothesis at Site 802 , where an unconformity between lower Eocene and upper Oligocene/lower Miocene sediments occurs at about 292 mbsf (Lancelot, Larson, et al., 1990), within upper Paleocene to lower Miocene nannofossil chalk (Unit III) (Figs. 1, 2, 6). XRD analyses show no significant differences in composition between the chalks above and below the unconformity. Scattered nodules of quartz chert, however, occur only below the hiatus surface, and a few opal-CT porcellanites occur only within the $8 \mathrm{~m}$ of sediment above it. The distribution of these minor amounts of chert and porcellanite $(<3 \%$ of recovery) within a relatively homogeneous chalk deposit allows us to use this hiatus as a natural experiment to evaluate the influence of time on chertification. In this section, upper Paleocene to lower Eocene deposits $(>52 \mathrm{Ma}$ ) lie directly below upper Oligocene or lower Miocene sediments ( $<30 \mathrm{Ma}$ ) - a gap of 22 to $34 \mathrm{~m} . \mathrm{y}$.

We observe the following sequence of diagenetic features with increasing depth (Fig. 6). At $265 \mathrm{mbsf}$ ( $27 \mathrm{~m}$ above the disconformity), a mixed-source calcareous/siliceous turbidite in Core 129-802A-30R, contains abundant pristine opal-A radiolarian tests and sponge spicules in addition to foraminifers and coccoliths. This kind of coarse-grained, calcareous/siliceous deposit is usually the preferred site of earliest silicification (Lancelot, 1973; Keene, 1975). The uppermost opal-CT porcellanite (Sample 129-802A-32R-1, 36-38 cm; $284 \mathrm{mbsf}$ ) and the highest occurrence of microfossil-filling chalce-dony were recovered in Core 32R, $8 \mathrm{~m}$ above the disconformity; these shallowest occurrences of silicified sediments are less than $30 \mathrm{~m} . \mathrm{y}$. old. The diagenesis

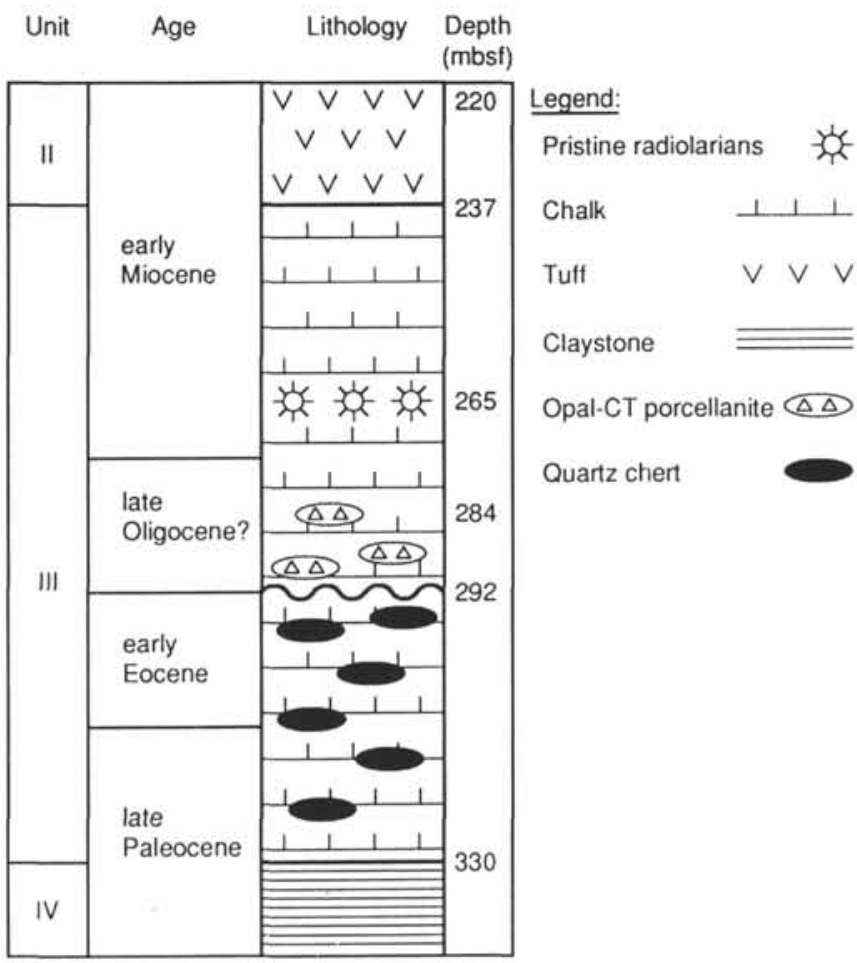

Figure 6. Stratigraphic relations of sedimentologic and diagenetic features above and below the Paleogene unconformity at Site 802 . 


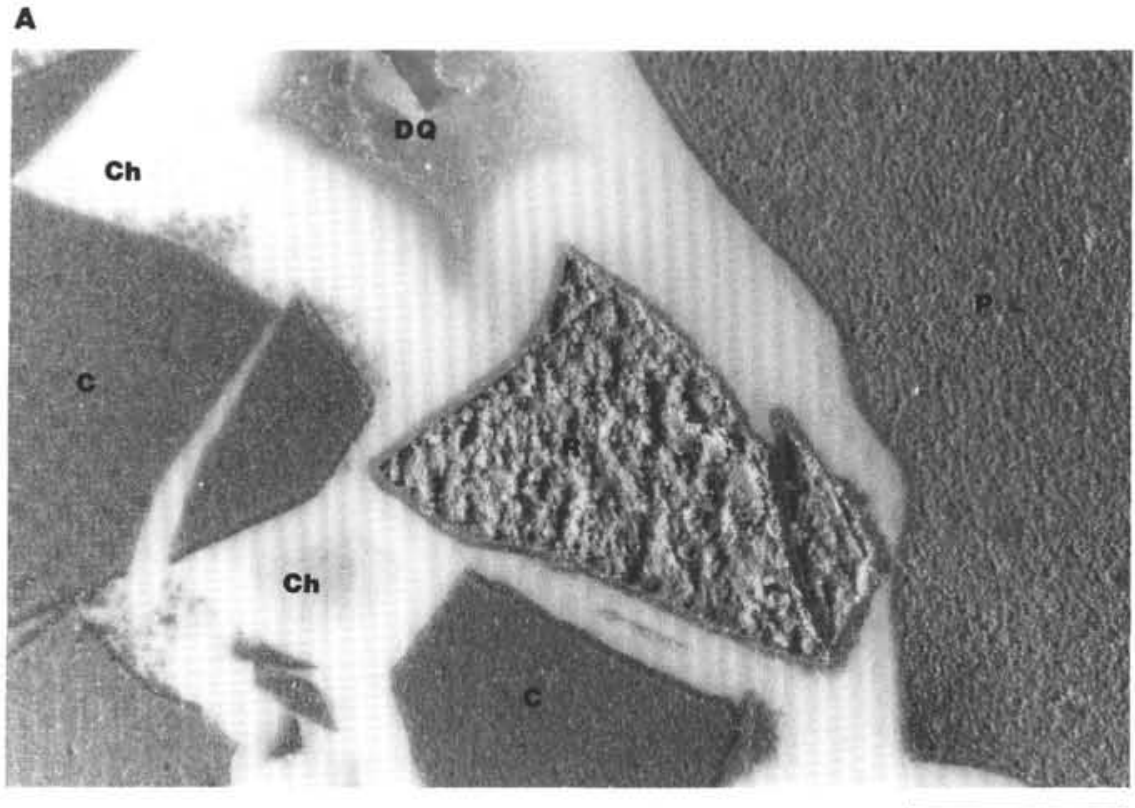

$1 \mathrm{~mm}$

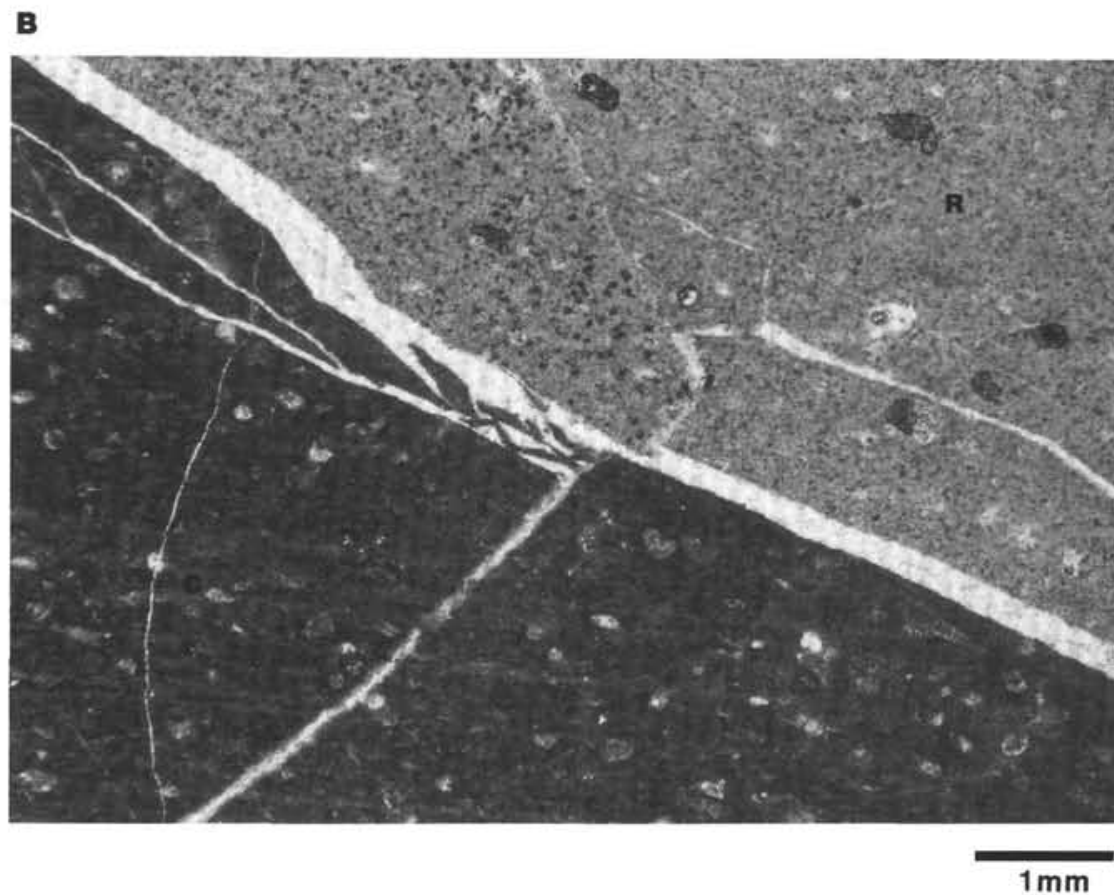

Figure 7. "Compartmented" breccia in which originally identical fragments of radiolarite have been differentially silicified to chert or porcellanite. A. Angular breccia fragments of radiolarite $(R)$, radiolarian porcellanite $(\mathrm{P})$, and radiolarian chert $(\mathrm{C})$ are cemented by isopachous chalcedony $(\mathrm{Ch})$ and drusy euhedral quartz (DQ). Fragments can be reassembled with a near perfect "jigsaw puzzle" fit; upper Tithonian, Sample 129-801B$21 \mathrm{R}-1,19-21 \mathrm{~cm}$. B. Photomicrograph of preserved Fe/Mn-oxides in radiolarian chert (C) and their absence in radiolarite $(\mathrm{R})$ across chalcedony-cemented fracture. Original sediments probably had identical compositions, but $\mathrm{Fe} / \mathrm{Mn}$-oxides in radiolarite were removed post-fracturing by reduction and dissolution. Plane light; lower Tithonian, Sample 129-801B-25R-1, 59-61 cm. C. Compartmented breccia microsampled for oxygen isotopic composition as described in text. Same sample as (A). Chalcedony cement $(\mathrm{Ch}) \delta^{18} \mathrm{O}=33.4 \%$ SMOW; $16^{\circ} \mathrm{C}$. Chert breccia fragment $(\mathrm{C}) \delta^{18} \mathrm{O}=31.6 \%$ SMOW; $22^{\circ} \mathrm{C}$. Porcellanite fragment (P). Radiolarite fragment $(R) \delta^{18} \mathrm{O}=30.2 \%$ SMOW; $28^{\circ} \mathrm{C}$. Drusy quartz cement (DQ) $\delta^{18} \mathrm{O}=28.0 \% \mathrm{SMOW} ; 28^{\circ} \mathrm{C}$. 


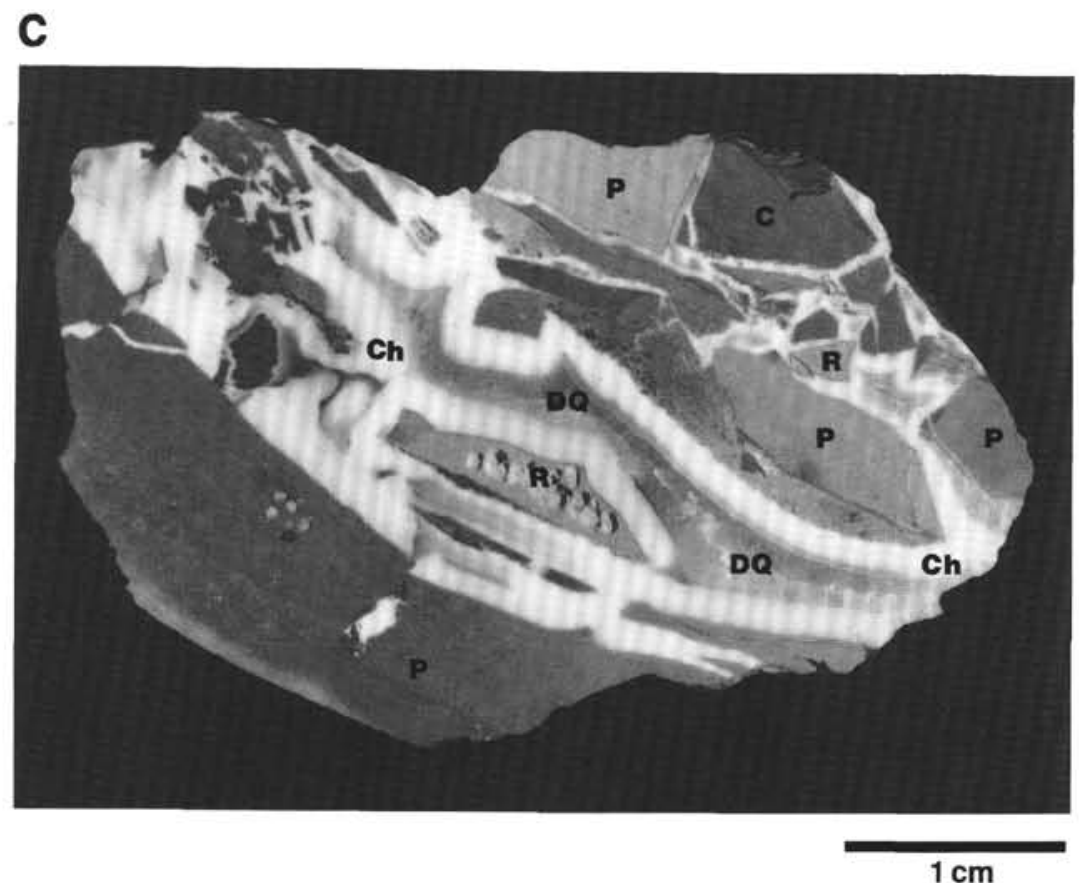

Figure 7 (continued).

is more advanced below the hiatal surface. Dense, vitreous quartz chert is moderately abundant in lower Eocene sediments just below the hiatus; the shallowest piece was recovered immediately below the hiatus at $293 \mathrm{mbsf}$ (Sample 129-802A-33R-1, 13-15 cm). In addition, radiolarians within the host chalk are replaced and filled by calcite, whereas many foraminifers are quartz-filled. Taken together, there is abundant petrographic evidence for silica and calcium carbonate mobilization and rearrangement.

These observations can be interpreted in two ways. Either time or composition was the critical factor for chertification - the presence of quartz chert below, but not above, the disconformity could be due to either. The excellent preservation of opal-A microfossils in the lower Miocene deposits above the hiatal surface, however, shows that insufficient silica supply was not the limiting factor as pristine radiolarians and sponge spicules have not yet dissolved and yielded silica for diagenetic reprecipitation. In contrast, the radiolarians in the lower Eocene chalk deposited prior to the hiatus underwent complete dissolution or replacement by calcite. Thus, time was probably the critical factor (after primary availability of biogenic silica in the original sediments) in the mobilization of silica for the formation of chert and porcellanite. Between $30 \mathrm{~m}$.y. and $52 \mathrm{~m}$.y. was required to form quartz cherts in primarily calcareous sediments in this deep-ocean setting. The few opal-CT porcellanites located just above the hiatal surface may have experienced early cementation due to their proximity to the older, pre-hiatus sediments and exposure to higher concentrations of dissolved silica diffusing upwards from below.

\section{PERMEABILITY AND CHERTIFICATION}

\section{Compartmented Breccias}

Chert, porcellanite, and radiolarite are commonly fractured or brecciated in response to tectonic deformation or burial compaction (Keene, 1975). In one form of breccia frequently recovered during Leg 129, originally adjacent and continuous fragments of siliceous rock are only slightly displaced from one another and cemented together by fracture-filling chalcedony or megaquartz. In Tithonian to Valanginian strata of Hole $801 \mathrm{~B}$, these breccias are composed of distinct fragments of porous, granular radiolarite, less porous porcel- lanite, and dense, vitreous chert, each of which formed from an originally identical and continuous protolith (Fig. 7A). This can be inferred from primary laminations that can be traced between fragments and by the perfect "jigsaw puzzle" fit of the adjacent fragments. Thus, individual breccia fragments, only millimeters apart, yet isolated by relatively impermeable cement, were buried in "compartments" with distinct diagenetic and silicification histories. These "compartmented" breccias provide a superb opportunity to evaluate the importance of fluid flow and addition of silica in the formation of cherts.

Across quartz and chalcedony-filled veins, cherts and radiolarites show nearly identical distribution and packing of radiolarians and thickness of laminations. The petrographic difference between more and less cherty fragments is primarily that of porosity and concentration of $\mathrm{Fe} / \mathrm{Mn}$-oxides. Cherts have low porosity and greater concentrations of dark-pigmented oxides, whereas porcellanites and radiolarites typically have greater porosity and fewer oxides than most other noncalcareous pelagic sediments (Fig. 7B). These two observations have, at first glance, contradictory implications. Porous radiolarite and porcellanite breccia fragments were closed to pore fluid circulation by fracture-filling cementation at a relatively early stage, preventing their complete silicification, yet they were open to Fe/Mn-oxide reduction, dissolution, and removal. The addition of pore-filling silica to the fragments that eventually became chert shows that they remained in communication with silica-bearing pore fluids after the radiolarite and porcellanite fragments were isolated, yet, in contrast to the radiolarite, they retained their original component of $\mathrm{Fe} / \mathrm{Mn}$-oxides.

Further insight into the diagenetic sequence is gained by oxygen isotopic analyses of breccia fragments and cement, microsampled in the manner of Prezbindowski (1980) (Fig. 7C; Sample 129-801B$21 \mathrm{R}-1,19-21 \mathrm{~cm})$. Opaque, white, isopachous chalcedony cement, which coats and binds the brecciated fragments, has the heaviest $\mathrm{O}$-isotopic composition, $\delta^{18} \mathrm{O}=33.4 \%$, indicating cementation at about $16^{\circ} \mathrm{C}$ (see "Oxygen Isotope Study" section, this chapter, for discussion of temperature expressions and assumptions). Sequentially lighter and yielding higher model temperatures of formation are the dense, vitreous quartz chert fragments $\left(\delta^{18} \mathrm{O}=31.6 \% ; 22^{\circ} \mathrm{C}\right)$, and the less dense, quartz-phase radiolarite fragments $\left(\delta^{18} \mathrm{O}=30.2 \%\right.$; $28^{\circ} \mathrm{C}$ ). Finally, void-filling, drusy megaquartz has the lowest $\delta^{18} \mathrm{O}$ 
Table 2. Oxygen isotope and mineralogic composition of samples from Sites 800,801 , and 802.

\begin{tabular}{|c|c|c|c|c|c|c|c|c|c|c|c|c|c|c|c|}
\hline $\begin{array}{l}\text { Core, section, } \\
\text { interval (cm) }\end{array}$ & $\begin{array}{l}\text { Depth } \\
\text { (mbsn) }\end{array}$ & Type & Lithology & Comments & $\begin{array}{c}8^{18} \mathrm{O} \\
\text { (8 V-SMOW) }\end{array}$ & $\begin{array}{c}8^{18} \mathrm{O} \\
\text { (8 avg. (s.d.) }\end{array}$ & $\begin{array}{l}\text { Temperature } \\
\left({ }^{\circ} \mathrm{C}\right)\end{array}$ & Quartz & Opal-CT & Opal-C & $\underset{\text { minerals }}{\text { Clay }}$ & Calcite & Clinoptilolite & K-spar & Hematite \\
\hline \multicolumn{16}{|c|}{$\begin{array}{l}\text { General isotopic samples: } \\
\text { 129-800A- }\end{array}$} \\
\hline${ }^{2} 8 \mathrm{R}-1,28-33$ & 59 & B & Radiolarian porcellanite & Opal-CT and quartz & $37.2,38.1,37.1$ & $37.5(0.5)$ & & 13 & 87 & & & & & & \\
\hline $\begin{array}{l}\text { 48R-1, 28-33 } \\
\text { "8R-1, 28-33 }\end{array}$ & $\begin{array}{l}59 \\
59\end{array}$ & $\begin{array}{l}\text { B } \\
\text { B }\end{array}$ & $\begin{array}{l}\text { Radiolarian porcellanite } \\
\text { Radiolarian porcellanite }\end{array}$ & $\begin{array}{l}\text { NaOH treated split; quarzz only } \\
\text { Calculated opal.CT value }\end{array}$ & $\begin{array}{c}29.8,30.0 \\
38.6\end{array}$ & $\begin{array}{l}29.9(0.1) \\
38.6\end{array}$ & 30 & 100 & & & & & & & \\
\hline${ }^{2} 13 \mathrm{R}-1,42-45$ & 107 & $C R$ & Chert with radiolarians & Microcrystalline guartz & & & & & & & & & & & \\
\hline $13 R-1,42-45$ & 107 & CR & Calcareous radiolarian porcellanite & $\begin{array}{l}\text { Microctrystalline quartz } \\
\text { Opal-CT and quartz }\end{array}$ & $30.2,30.8$ & $30.8(0.1)$ & 26 & 100 & & & & & & & \\
\hline & 107 & $\mathrm{CR}$ & $\begin{array}{l}\text { Cacaracoun sadololanan porcellante } \\
\text { Calcarcous radiolarian porcellanite }\end{array}$ & $\begin{array}{l}\text { pal-CT and quartz } \\
\mathrm{NaOH} \text { treated split: quartz only }\end{array}$ & $\begin{array}{l}34.3,34.7 \\
309.316\end{array}$ & $\begin{array}{l}34.5(0.2) \\
33.3(0.4)\end{array}$ & 24 & 27 & 44 & & & 29 & & & \\
\hline${ }^{\prime} 13 R-1,42-45$ & 107 & $\mathrm{CR}$ & Calcareous radiolarian porcellanite & Calculated opal-CT value & 36.5 & 36.5 & $2 \pi$ & & & & & & & & \\
\hline $14 \mathrm{R}-1,22-25$ & 116 & CR & Radiolarian chert & Microcrystalline quartz & $32.6,32.6$ & $32.6(0.0)$ & 18 & 96 & & & 2 & 2 & & & \\
\hline $30 R-2,1-3$ & 267 & V/B & Radiolarian porcellanite & Opal-CT, quarzz, and clay & 33.1 & 33.1 & & 27 & 57 & & 16 & & & & \\
\hline $43 R-1.125-128$ & 376 & $\mathrm{v}$ & Radiolarian chert & Microcrystalline quartz & $30.9,30.9$ & $30.9(0.0)$ & 25 & 84 & & & 16 & & & & \\
\hline $56 R-1,41-43$ & 489 & $\mathrm{~T}$ & Radiolarian cherty porcellanite & Microcrystalline quartz & $29.2,29.3$ & $29.3(0.1)$ & 32 & $\mathrm{P}$ & & & & & & & M \\
\hline \multicolumn{16}{|l|}{ 129-801A- } \\
\hline${ }^{2} 12 \mathrm{R}-1,17-19$ & 107 & B & Radiolarian chent & Opal-CT and quartz split & $34.5,35.5$ & $35.0(0.5)$ & & 18 & 82 & & & & & & \\
\hline $12 \mathrm{R}-1,17-19$ & 107 & B & Radiolarian chert & $\mathrm{NaOH}$ treated split; quartz only & 27.3 .28 .2 & $27.8(0.5)$ & 39 & 100 & & & & & & & \\
\hline $12 R-1,17-19$ & 107 & B & Radiolarian chert & Calculated opal-CT value & 36.5 & 36.5 & & & & & & & & & \\
\hline \multicolumn{16}{|l|}{ 129-801B- } \\
\hline "17R-1, 29-33 & 347 & B & Radiolarian porcellanite & Microcrystalline quarz + opal-CT & 31.8 & 31.8 & 22? & 80 & & 20 & & & & & \\
\hline $24 \mathrm{R}-1,28-31$ & 347 & B & Radiolarian chert nodule & Microcrystalline quartz & $30.6,31.3$ & $31.0(0.4)$ & 25 & 92 & 1 & & 6 & & & & \\
\hline $24 \mathrm{R}-1,28-31$ & 401 & B & Radiolarian chent & Microcrystalline quartz & $31.4,31.6$ & $31.5(0.1)$ & 23 & 100 & & & is & & & & \\
\hline $\begin{array}{l}29 \mathrm{R}-1,11-13 \\
{ }_{4}^{4} \mathrm{R}-1,3-5\end{array}$ & 要243 & $\stackrel{B}{T}$ & Radiolarian chert & Microcrystalline quartz & $\begin{array}{l}31.3,31.3 \\
-2866,21\end{array}-1$ & $31.3(0.0)$ & 24 & 99 & & & 1 & & & & \\
\hline \multirow{2}{*}{\multicolumn{16}{|c|}{ 129-802A. }} \\
\hline & & & & & & & & & & & & & & & \\
\hline $32 R-1,36-38$ & 284 & CR & Cherty porcellanite & Opal-CT & $37.4,38.4$ & $37.9(0.5)$ & & & $\mathrm{p}$ & & & $\mathbf{P}$ & & & \\
\hline $34 R-1,135-137$ & 304 & $\mathrm{CR}$ & Chert within chalk & Microcrystalline quartz & 35.7 & 35.7 & 7 & 100 & & & tr & & & & \\
\hline $\begin{array}{l}35 \mathrm{R}-1,26-29 \\
39 \mathrm{R}-1,37-39\end{array}$ & $\begin{array}{l}312 \\
349\end{array}$ & $\begin{array}{c}\text { CR } \\
\text { B }\end{array}$ & $\begin{array}{l}\text { Calcareous porcellanite } \\
\text { Radiolarian porcellanite }\end{array}$ & $\begin{array}{l}\text { Opal-CT, minor quartz } \\
\text { Opal-CT, minor quartz }\end{array}$ & $\begin{array}{l}38.8 .39 .8 \\
37.5 .38 .1\end{array}$ & $\begin{array}{l}39.3(0.5) \\
37.8(0.3)\end{array}$ & & $\begin{array}{l}3 \\
4\end{array}$ & $\begin{array}{l}57 \\
92\end{array}$ & & tr & 40 & 4 & & \\
\hline '54R-1, 87-89 & 479 & CR & Siliceous nannofossil chalk & Opal-CT and quartz & 32.5. 33.0,33.8 & $33.1(0.6)$ & & 26 & 20 & & & 54 & & & \\
\hline & 479 & CR & With chalcedony-filled radiolarians & $\mathrm{NaOH}$ treated split; quarz only & $32.0,32.7$ & $32.4(0.4)$ & 19 & 100 & & & & & & & \\
\hline "54R-1, 87-89 & 479 & CR & With chalcedony-filled radiolarians & Calculated opal-CT value & 34.1 & 34.1 & & & & & & & & & \\
\hline${ }^{b} 54 R-1,87-89$ & 479 & CR & Chen & Microcrystalline quartz & 31.7 .32 .0 & $31.9(0.2)$ & 21 & 100 & & & & & & & \\
\hline \multicolumn{16}{|c|}{$\begin{array}{l}\text { Compartmented breccia microsamples: } \\
\text { 129-801B. }\end{array}$} \\
\hline $21 R-1,19-21$ & 384 & & Radiolarite fragment in breccia & Microcrystalline quartz & 30.2 & 30.2 & 28 & P & & & & & & & \\
\hline '21R-1, 19-21 & 384 & & Chen fragment in breccia & Microcrystalline quartz & 31.6 & 31.6 & 22 & $P$ & & & & & & & \\
\hline $521 R-1,19-21$ & 384 & & $\begin{array}{l}\text { White chalcedony cement } \\
\text { Drusy megaquartz }\end{array}$ & $\begin{array}{l}\text { Chalcedony } \\
\text { Megaquartz }\end{array}$ & 33.4 & 33.4 & $\begin{array}{l}16 \\
38\end{array}$ & $\begin{array}{l}100 \\
100\end{array}$ & & & & & & & \\
\hline${ }^{2} 21 \mathrm{R}-1,19-21$ & 384 & & Drusy megaquartz & Megaquartz & 28 & 28 & 38 & 100 & & & & & & & \\
\hline \multicolumn{16}{|c|}{ Controls for sodium hydrosulfite treatment: } \\
\hline $\begin{array}{l}\text { 801B-29R-I. } 11-13 \\
802 A-39 R-137-39\end{array}$ & ${ }_{349}^{424}$ & $\stackrel{\mathrm{B}}{\mathrm{B}}$ & $\begin{array}{l}\text { Radiolarian cher, minor iron oxides } \\
\text { Radiolarian porcellanite. Fe/Mn oxide-rich }\end{array}$ & $\begin{array}{l}\text { Microcrystalline quartz } \\
\text { Opal-CT, minor quartz }\end{array}$ & $\begin{array}{l}31.3 \\
36.7 .37 .8\end{array}$ & $\begin{array}{c}31.3 \\
37.3(0.6)\end{array}$ & 24 & ${ }_{4}^{99}$ & 92 & & $\begin{array}{l}1 \\
\text { tr }\end{array}$ & & 4 & & \\
\hline
\end{tabular}

Notes: Siliceous rock types: $C R=$ carbonate replacenent; $B=$ bedded (clayey-siliceous); $V=$ volcaniclastic/volcanic-related: $T=$ thermal. s.d. = standard deviation. Temperature: Knauth and Epstein (1976), assuming that pore water = -1 \& SMOW. Qualitative XRD: $P=$ principle component

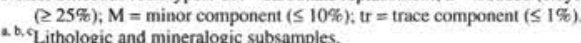




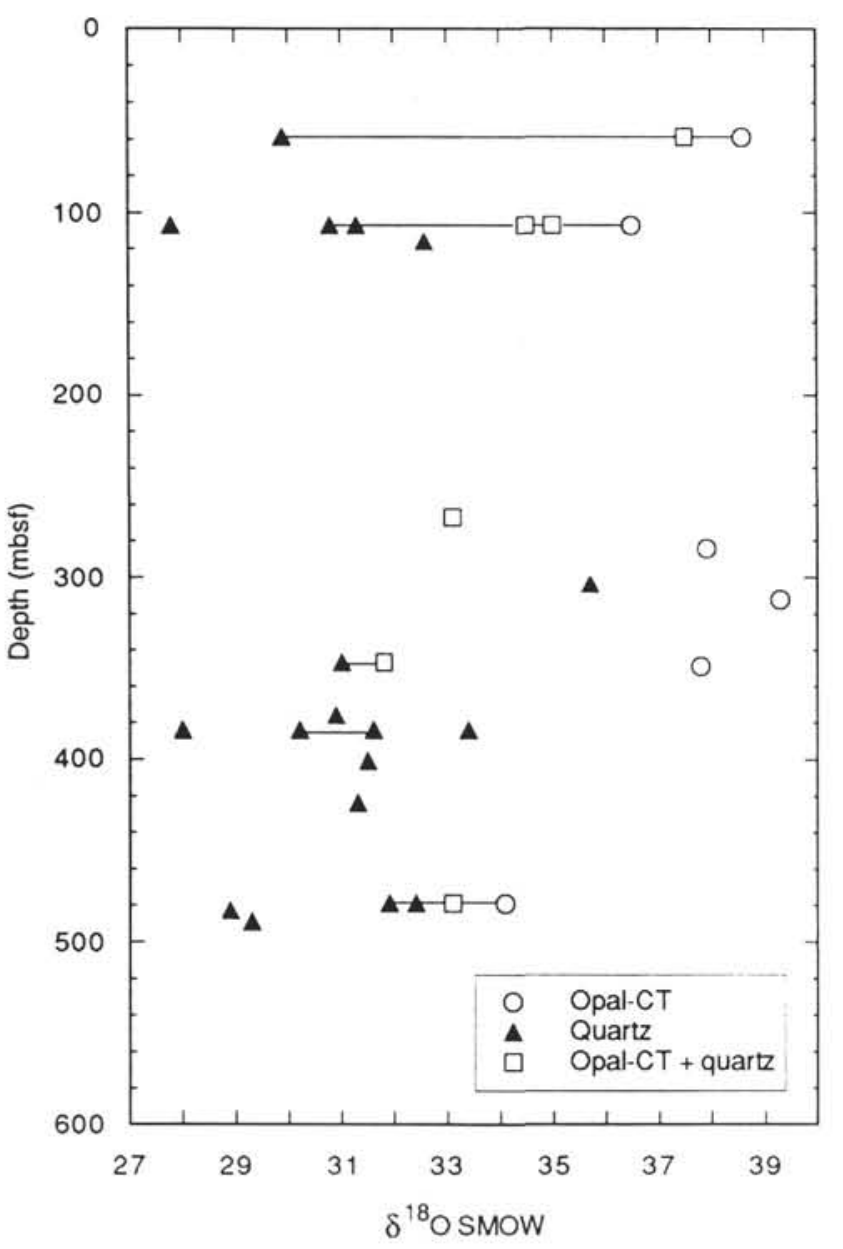

Figure 8. Oxygen isotope composition of Leg 129 chert and porcellanite plotted vs. depth. Horizontal lines connect individual silica phases separated from the same sample or samples from different lithologies across a diagenetic or stratigraphic boundary.

value $\left(28.0 \% ; 38^{\circ} \mathrm{C}\right)$. Assuming a relatively constant or gradually decreasing $\delta^{18} \mathrm{O}_{\text {pore water, }}$ we can interpret these data, in combination with our petrographic observations, as evidence for the following diagenetic sequence:

1. Incipient lithification of radiolarian-rich and $\mathrm{Fe} / \mathrm{Mn}$-oxide-rich sediment, probably by opal-CT cementation.

2. Brecciation of the still-porous radiolarite.

3. Isopachous cementation of breccia fragments by length-fast chalcedony resulting in "compartmented" fragments with different degrees of isolation from free communication with pore water $\left(16^{\circ} \mathrm{C}\right)$.

4. Silicification of radiolarite fragments that were still open to free pore-water communication into dense vitreous radiolarian chert by the localized addition of silica $\left(22^{\circ} \mathrm{C}\right)$. Formation of a dense, tightly fitted mosaic of microcrystalline quartz and chalcedony isolated the disseminated oxides from interaction with large volumes of pore water.

5. Radiolarite fragments that were partially or fully isolated within low permeability compartments gained little or no external silica, and remained porous radiolarite or were weakly silicified to radiolarian porcellanite $\left(28^{\circ} \mathrm{C}\right)$. Some radiolarite fragments developed additional, secondary porosity by the volume-reducing inversion of opalCT to quartz within a rigid compartment that was sheltered from sedimentary load compaction.

6. Fe/Mn-oxides were partially dissolved from porous radiolarite and porcellanite fragments that were not completely isolated by sur-
A

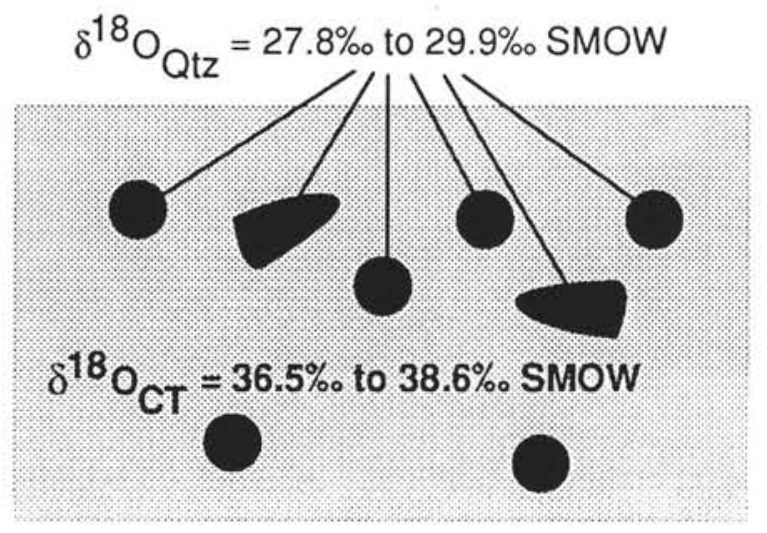

B

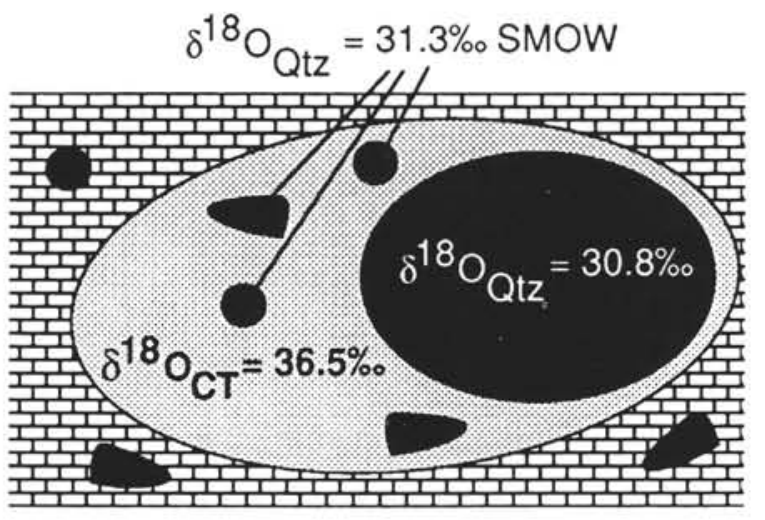

quartz chert or radiolarian-filling chalcedony

opal-CT matrix and cement

siliceous limestone with radiolarians

Figure 9. Schematic diagrams of oxygen isotope compositions of opal-CT, quartz, and chalcedony. A. Upper Cretaceous radiolarian porcellanite with opal-CT matrix and chalcedony-filled radiolarians. Samples 129-800A$8 \mathrm{R}-1,28-33 \mathrm{~cm}$, and $129-801 \mathrm{~A}-12 \mathrm{R}-1,17-19 \mathrm{~cm}$. B. Nodular quartz chert with opal-CT porcellanite rim in Cenomanian radiolarian-bearing limestone. Sample 129-800A-13R-1, 42-45 cm.

rounding chalcedony from reducing external pore waters. It is somewhat problematic that "isolated" radiolarite fragments also show some $\mathrm{Fe} / \mathrm{Mn}$-oxide depletion, thereby being closed to silicification, yet open to $\mathrm{Fe} / \mathrm{Mn}$-oxide dissolution. Reduction and removal of oxides may be able to proceed by slower diffusive transport, even when closed to significant advection. Abundant $\mathrm{Fe} / \mathrm{Mn}$-oxides remain "locked" into the dense, impermeable chert fragments.

7. Drusy megaquartz filled in most of the still-open fractures between the chalcedony-coated breccia fragments $\left(38^{\circ} \mathrm{C}\right)$.

In summary, the "compartmented" differential diagenesis of originally identical breccia fragments, isolated by fracturing and cementation, demonstrates that silicification (local addition of silica) is required to form dense, vitreous cherts.

\section{Secondary Porosity from the Opal-CT to Quartz Transformation}

Even with the relatively low permeability of most siliceous rocks, dissolved silica during the opal-CT to quartz transformation does not necessarily reprecipitate exactly in situ. Dense chert, however, whether 
composed of opal-CT or quartz, is nearly impermeable to pore fluids and can restrict the mobility of dissolved silica. In thin section, very small $(3-10 \mu \mathrm{m})$, dark, nearly opaque, granular "inclusions" with low refractive index occur within quartz carbonate-replacement cherts and near the boundaries with opal-CT chert. These are the same size and shape as opal-CT lepispheres composing the groundmass of the opalCT chert. They are also similar in location and opacity to impurities described by Lancelot (1973), but contain no birefringent clay minerals. Under BSEM examination, the "inclusions" proved to be subspherical pores, completely surrounded by microcrystalline quartz (Pl. 5, Fig. 1). A narrow zone of increased porosity at the quartz/opalCT transformation front in chert was also noted by Wise and Weaver (1974), who described small $(2-3 \mu \mathrm{m})$, hollow centers of silica microspherulites. We also find these at the center of chalcedony spherules (Pl. 5, Fig. 2) and interpret these pores to be lepisphere moldic secondary porosity, created when opal-CT lepispheres that became enclosed and completely isolated by surrounding chalcedonic quartz, inverted to microcrystalline quartz with an associated decrease in volume. Opal-CT lepispheres can become isolated from pore-water communication by overgrowth of chalcedony cement or by the transformation of the surrounding matrix to microcrystalline quartz at an advancing chertification front. Within such a closed system, the inversion of opal-CT (grain density $=2.3 \mathrm{gm} / \mathrm{cm}^{3}$ ) to microcrystalline quartz (grain density $=2.6 \mathrm{gm} / \mathrm{cm}^{3}$ ) should generate $12 \%$ porosity within the space of the original opal-CT lepisphere.

We also observe opal-CT to quartz secondary moldic porosity in radiolarian tests that had been completely replaced by opal-CT prior to quartz chertification of the enclosing sediment. Volume reduction of the opal-CT test during conversion to quartz in a effectively closed system creates secondary moldic porosity that can either form complex macropores, 10-100 $\mu \mathrm{m}$ in diameter (Pl. 5, Fig. 3), or swarms of surrounding micropores, each only a few micrometers thick (Pl. 5, Fig. 4).

These observations point out the importance of silica mobility in the filling in of porosity in order to form dense quartz cherts, even if the necessary transport distance may be only on a scale of centimeters.

\section{OXYGEN ISOTOPE STUDY}

Chert, porcellanite, and radiolarite samples were selected for oxygen isotopic analyses based on stratigraphic location and process of chertification, or to address specific diagenetic questions, such as the relative timing of silica precipitation inside and outside of a nodule or between fragments in a breccia. Oxygen isotope results are displayed in Table 2 and on Figures 8 and $9 . \delta^{18} \mathrm{O}$ values of all carbonate- and $\mathrm{Fe} / \mathrm{Mn}$-oxidefree whole-rock samples range from $28.9 \%$ to $39.3 \%$. Pure opal-CT (directly measured or calculated by the method of Pisciotto, 1981a; see "Methods" section, this chapter) ranges from $34.1 \%$ to $39.3 \%$, whereas quartz values are consistently lower $(27.8 \%$ to $35.7 \%)$. These measurements fall within the range of previous analyses of deep-sea cherts and porcellanites (Kolodny and Epstein, 1976; Hein and Yeh, 1981).

\section{Co-existing Opal-CT and Quartz}

The shallowest radiolarian cherts and porcellanites recovered by Leg 129 (Upper Cretaceous of Sites 800 and 801) contain opal-CT that is $8 \%-9 \%$ richer in ${ }^{18} \mathrm{O}$ than co-existing chalcedonic quartz. Chalcedony exists exclusively as the internal filling of radiolarians, whereas opal-CT composes the matrix of the siliceous rocks. Two samples of the Upper Cretaceous radiolarian porcellanite and chert (Samples 129-801A-12R-1, 17-19 cm; 129-800A-8R-1, 28-33 cm) yield $\delta^{18} \mathrm{O}_{\text {opal-CT }}=36.5 \%$ and $38.6 \%$ and $\delta^{18} \mathrm{O}_{\text {chalcedony }}=27.8 \%$ and $29.9 \%$, respectively (Fig. 9A), i.e., an $8.7 \%$ depletion for chalcedonic quartz in both samples. This difference between co-existing opal-CT and quartz is much larger than the $0.5 \%-2.0 \%$ deviations reported for deep-sea cherts from which opal-CT and quartz were apparently sampled from adjacent, but not identical lithologies
(Knauth and Epstein, 1975; Kolodny and Epstein, 1976). Pisciotto (1981a) chemically separated the two silica phases from single samples from the Monterey Formation, California, and found diagenetic quartz depleted $2 \%-5 \%$ in cherts and $4 \% 0-7 \%$ in porcellanites, values closer to those determined in this study.

The $8.7 \%$ difference in $\mathrm{O}$-isotopic composition between co-existing opal-CT and chalcedonic quartz cannot be simply explained by changes in temperature or pore-water composition, or both, using typical gradients for abyssal, deep-sea settings. These samples were recovered from 59 and 107 mbsf; typical pore-water profiles for deep-sea pelagic sediments show only $1 \%-3 \%$ depletion in 400 to $600 \mathrm{~m}$ of sedimentary section (Pisciotto, 1981b) and could contribute at most $1 \%$ to the $\delta^{18} \mathrm{O}$ difference between opal-CT and quartz even if opal-CT formed at the seafloor and chalcedony precipitated at maximum burial depth. Likewise, geothermal gradients of about $5^{\circ} \mathrm{C} / 100 \mathrm{~m}$ (Sites 800 and 801 apatite fission track study, Vrolijk et al., this volume; undisturbed sediments, Nauru Basin; Fujii, 1986) would establish a maximum difference of $5^{\circ} \mathrm{C}$ between 0 and $107 \mathrm{mbsf}-\mathrm{a}$ potential contribution of less than $2 \%$ to the quartz depletion in ${ }^{18} \mathrm{O}$. Thus, typical temperature and pore-water $\mathrm{O}$-isotope gradients could account for only $3 \%$ of the $8.7 \%$ difference between co-existing quartz and opal-CT. We must, therefore, consider the possibilities of nonconservative or transient pore-water profiles.

Thick Aptian to Albian-Cenomanian basaltic volcaniclastic deposits directly underlay the Upper Cretaceous radiolarian chert and porcellanite at Site 801 and are separated from them by $150 \mathrm{~m}$ of chalk and limestone at Site 800 . Alteration of basalts to clay minerals or zeolites is an important fractionating process for the removal of ${ }^{18} \mathrm{O}$ from pore waters (Gieskes and Lawrence, 1981) and is responsible for ${ }^{18} \mathrm{O}$ depletions of up to $4.5 \%$ (ODP Site 737, Chambers, 1991). As temperature gradients cannot account for the difference in $\delta^{18} \mathrm{O}$ values, opal-CT and chalcedonic quartz probably precipitated in equilibrium with pore waters of significantly different $\mathrm{O}$-isotopic composition. Opal-CT precipitated first and probably shallowly, most likely in diffusional contact and in equilibrium with early Tertiary seawater. Conversion of opal-A to opal-CT greatly reduced permeability in the chert and porcellanite layers and modern pore-water profiles reflect very low rates of diffusion below them (France-Lanord and Sheppard, this volume). Thus, pore waters within and below the Upper Cretaceous radiolarian-rich deposits became isolated from overlying seawater after the formation of opal-CT cherts and porcellanites. We suggest that alteration of thick, underlying volcaniclastic deposits may have reduced $\delta^{18} \mathrm{O}_{\text {pore water }}$ as much as $6 \%$ - $8 \%$ prior to chalcedony precipitation. The remaining depletion in ${ }^{18} \mathrm{O}$ (to reach $8.7 \%$ ) is potentially due to temperature differences and the diagenetic reactions of siliceous and calcareous sediments (Lawrence, 1989).

An alternate interpretation could be that the precipitation of opalCT fractionates ${ }^{18} \mathrm{O}$ differently with respect to temperature than does chalcedonic quartz, and that the difference in $\delta^{18} \mathrm{O}$ is largely due to this difference in fractionation, not to changes in the environment of precipitation. If this is the case, our data could support the suggestion of Riech and von Rad (1979) that opal-CT and quartz may possess different fractionation factors, a. The commonly used fractionation expressions for silica and water (e.g., Knauth and Epstein, 1976; Clayton et al., 1972) are based upon experimental data on the quartzwater system and empirical observation of the diagenetic environment of deep-sea quartz cherts. Previous workers have assumed, with little data, that opal-CT responds in a quantitatively equivalent fashion. In this matter of the Upper Cretaceous chert and porcellanite of Sites 800 and 801 , however, it is the chalcedonic quartz that possesses geologically unreasonable (low) $\delta^{18} \mathrm{O}$ values without considering changes in the composition of the pore water, and so a distinct fractionation factor for the opal-CT-water system cannot explain the $8.7 \%$ difference between opal-CT and chalcedonic quartz.

Knauth and Epstein's (1976) oxygen isotope fractionation expression for quartz and water was reasonably confirmed for deep-sea cherts 
and porcellanites by Hein and Yeh (1981), and we use it to estimate the minimum temperatures of formation of opal-CT and quartz (Table 2). For this purpose, we assume that the isotopic composition of Mesozoic and Tertiary seawater was about $\delta^{18} \mathrm{O}=-1.0 \%$ V-SMOW (Savin, 1977). Pore-water profiles from abyssal settings are quite variable, but commonly show a trend of slight ${ }^{18} \mathrm{O}$ depletion with depth, averaging about $-0.5 \%$ per 100 mbsf (Pisciotto, 1981b). To incorporate this gradient into our temperature calculations, however, would require us to assume that the measured silica phases formed at or near their present depth, and we feel that this assumption would introduce additional potential error and obscure basic trends in the data. We therefore assume for our temperature calculations that $\delta^{18} \mathrm{O}_{\text {pore water }}=$ $-1.0 \%$ (that of paleosea-water at time of deposition). Two model temperatures for opal-CT based on this assumption yield unreasonably low values $\left(-2^{\circ}\right.$ and $\left.-4^{\circ} \mathrm{C}\right)$, which indicates that either $\delta^{18} \mathrm{O}_{\text {pore water }}$ was $1 \%$ - $2 \%$ higher than estimated at the times of their precipitation, or the quartz-water fractionation expression used in this study (Knauth and Epstein, 1976) yields model temperatures for opal-CT that are at least $4^{\circ} \mathrm{C}$ too low. Although it is the most commonly used expression in silica diagenesis studies, Knauth and Epstein's (1976) equation yields the lowest temperatures of all of the half dozen or more proposed fractionation relationships. Ongoing work in the Monterey Formation of California is using early-formed cherts within opal-A diatomite to evaluate the various temperature expressions for use on opal-CT cherts (Behl et al., unpubl. data, 1991).

\section{Carbonate-replacement Chert and Porcellanite}

Three of four quartz chert nodules have $\mathrm{O}$-isotopic compositions of $\delta^{18} \mathrm{O}_{\text {quartz }}=30.8 \%$ to $32.6 \%$, resulting in model temperatures of formation of $18^{\circ}$ to $26^{\circ} \mathrm{C}$. The remaining quartz chert was recovered from directly below the Site 802 hiatus and is richer in ${ }^{18} \mathrm{O}\left(\delta^{18} \mathrm{O}=\right.$ $35.7 \%$ ), indicating chertification at lower temperature $\left(\sim 7^{\circ} \mathrm{C}\right)$. The opal-CT in calcareous porcellanites have generally higher $\delta^{18} \mathrm{O}$ values $(34.1 \%$ to $39.3 \%$ ) than the quartz cherts and lower model precipitation temperatures $\left(-4^{\circ}\left(\right.\right.$ ?) to $\left.13^{\circ} \mathrm{C}\right)$. The highest and lowest $\delta^{18} \mathrm{O}_{\text {opal-CT }}$ values measured both reflect atypical burial histories; the highest $\delta^{18} \mathrm{O}$ value of $39.3 \%$ is from 20 m below the Site 802 hiatus, confirming that subhiatus cherts and porcellanites formed at relatively shallow burial depths. The lowest $\delta^{18} \mathrm{O}_{\text {opal-CT }}$ value (34.1 $\%$ ) occurs in late Aptian-Cenomanian porcellanite that was rapidly buried beneath Upper Cretaceous volcaniclastic turbidites.

In one sample, radiolarian-filling chalcedonic quartz $\left(\delta^{18} \mathrm{O}=31.3 \%\right.$ ) from the calcareous porcellanite rim of a chert nodule is $0.5 \%$ richer in ${ }^{18} \mathrm{O}$ than quartz in the chert center $\left(\delta^{18} \mathrm{O}=30.8 \%\right.$ ), surrounding opal-CT is richer still $\left(\delta^{18} \mathrm{O}=36.5 \%\right.$ ) (Fig. 9B; Sample 129-800A$13 \mathrm{R}-1,42-45 \mathrm{~cm})$. These data indicate that microfossils were filled with chalcedony after opal-CT precipitated, but prior to quartz chertification of the nodule center. In another sample, chalcedony-filled radiolarians in chalk have a different relationship to quartz chert (Sample 129-802A-54R-1, 87-89), in which the $\delta^{18} \mathrm{O}$ value of radiolarian chalcedony is $2.2 \%$ lower than that of chert. Although these two examples suggest that there is not a consistent sequence of silicification between the filling of radiolarians and the formation of quartz chert nodules in chalk, our O-isotope data show that carbonate-replacement quartz cherts have the highest $\delta^{18} \mathrm{O}$ values (lowest model temperatures of formation) of all quartz cherts measured.

\section{Bedded Chert and Porcellanite}

The O-isotopic compositions of whole-rock samples of bedded chert and porcellanite range from $\delta^{18} \mathrm{O}=31.0 \%$ to $37.5 \%$. Upper Cretaceous bedded cherts and porcellanite are composed of greater than $80 \%$ opal$\mathrm{CT}$ and have whole-rock $\delta^{18} \mathrm{O}$ values of $35.0 \%$ to $37.5 \%$, opal-CT values of $36.5 \%$ to $38.6 \%\left(-2^{\circ}(?)\right.$ to $\left.4^{\circ} \mathrm{C}\right)$, and radiolarian-filling chalcedonic quartz ( $<20 \%$ of sample) values of $27.8 \%$ to $29.9 \%$ (Fig. 9A).
Thus these opal-CT cherts and porcellanites formed shallowly, and as discussed earlier, the low $\delta^{18} \mathrm{O}_{\text {chalcedony }}$ values probably resulted from equilibration with ${ }^{18} \mathrm{O}$-depleted pore waters and do not reflect precipitation at higher temperatures. In contrast, Kimmeridgian to Valanginian bedded radiolarian cherts and porcellanites sampled over $80 \mathrm{~m}$ of Hole $801 \mathrm{~B}$ are composed of $80 \%-100 \%$ quartz, and vary only from $\delta^{18} \mathrm{O}=31.0 \%$ to $31.8 \%$. This maximum variation was measured across a single chert/porcellanite diagenetic boundary and indicates quartz formation between $22^{\circ}-25^{\circ} \mathrm{C}$.

\section{Thermal Cherts}

We analyzed two samples of thermal cherts from Sites 800 and 801 . Both were recovered from next to basaltic sills or flows, contain only quartz-phase silica, and display coarse microtextures in thinsection. One is a silicified radiolarian porcellanite (Sample 129$800 \mathrm{~A}-56 \mathrm{R}-1,41-43 \mathrm{~cm}$ ), the other is a chertified claystone crackle breccia with desiccation cracks (Sample 129-801B-41R-1, 3-5 cm; similar to Pl. 3, Figs. 1 and 2). Their O-isotopic compositions are $28.9 \%$ and $29.3 \%$, two of the lowest $\delta^{18} \mathrm{O}$ values measured, indicating quartz crystallization at $34^{\circ}$ and $32^{\circ} \mathrm{C}$, respectively.

\section{Volcanic-related Chert and Porcellanite}

We measured the O-isotopic compositions of two volcanic-related siliceous rocks, a porcellanite and a chert, each of which contained $16 \%$ clay minerals. O-isotopic analysis of sediments containing both silica and clay can give $\delta^{18} \mathrm{O}$ values shifted away from the true ${ }^{18} \mathrm{O}$ composition of the silica phase of interest. However, Hein and Yeh (1981) found no correlation between $\delta^{18} \mathrm{O}$ and $\mathrm{Al}_{2} \mathrm{O}_{3}$ in their study of deep-sea chert and porcellanite and suggested that minor amounts of contamination by terrigenous and volcanic detritus $\left(<7.57 \% \mathrm{Al}_{2} \mathrm{O}_{3}\right)$ did not significantly affect their $\mathrm{O}$-isotopic analyses. We feel likewise that our measurements of clay-bearing volcanic-related siliceous rocks are meaningful ( $16 \%$ smectite equals only $\sim 4.5 \% \mathrm{Al}_{2} \mathrm{O}_{3}$ ). The porcellanite measured is composed of $27 \%$ quartz, $57 \%$ opal-CT, and $16 \%$ clay minerals and has $\delta^{18} \mathrm{O}=33.1 \%$, similar to other whole-rock samples with subequal mixtures of quartz and opal-CT. The chert is composed of $84 \%$ quartz and $16 \%$ clay minerals, and has $\delta^{18} \mathrm{O}=30.9$ $\%$, within the range for bedded quartz cherts. The volcanic-related quartz chert formed at $\sim 25^{\circ} \mathrm{C}$, the mixed-phase porcellanite at $\sim 17^{\circ} \mathrm{C}$. We find no distinct isotopic signature that uniquely characterizes these two volcanic-related siliceous rocks.

\section{CONCLUSIONS}

We draw the following conclusions from this study:

1. Leg 129 recovered several types of chert and porcellanite, distinguished by processes of chertification and host lithologies, including carbonate-replacement, bedded (clayey-biosiliceous), thermal, and volcanic-related varieties.

2. Local addition of silica is necessary for the formation of dense, vitreous cherts as shown by ubiquitous, discordant chertification fronts and differential silicification of fragments in "compartmented" breccias.

3. Secondary moldic porosity is formed by volume reduction of opal-CT lepispheres and replaced microfossils at the opal-CT to quartz inversion when the transformation occurs in a closed system, iso-lated from pore waters by surrounding, impermeable microcrystalline quartz chert.

4. Between 30 and $52 \mathrm{~m} . y$. is required for the formation of quartz chert within calcareous-siliceous deposits, as shown by quartz cherts below and not above a Paleogene hiatus at Site 802 .

5 . The $d_{101}$ spacing of opal-CT decreases only generally with depth and age, and does not display any clear or predictable ordering. 
Considerable variation exists in the opal-CT $\mathrm{d}_{101}$ spacing of adjacent samples of different compositions.

6. The oxygen isotopic composition for all carbonate- and $\mathrm{Fe} /$ $\mathrm{Mn}$-oxide-free whole-rock samples measured range from $\delta^{18} \mathrm{O}=$ $28.9 \%$ to $39.3 \%$. $\delta^{18} \mathrm{O}$ for opal-CT $(34.1 \%$ to $39.3 \%)$ is consistently higher than that for associated quartz ( $27.8 \%$ to $35.7 \%$ ).

7. Carbonate-replacement quartz cherts have $\mathrm{O}$-isotopic compositions of $\delta^{18} \mathrm{O}=30.8 \%$ to $35.7 \%$, signifying formation at model temperatures of $7^{\circ}$ to $26^{\circ} \mathrm{C}$, whereas $\delta^{18} \mathrm{O}_{\text {opal-CT }}$ in calcareous porcellanites ranges from $34.1 \%$ to $39.3 \%$, reflecting precipitation at less than $13^{\circ} \mathrm{C}$.

8. Bedded chert and porcellanite consisting mostly of opal-CT have whole-rock $\mathrm{O}$-isotopic compositions of $\delta^{18} \mathrm{O}=35.0 \%$ to $37.5 \%$, with $\delta^{18} \mathrm{O}_{\text {opal-CT }}=36.5 \%$ to $38.6 \%$, reflecting precipitation at temperatures less than $4^{\circ} \mathrm{C}$. Quartz bedded cherts and porcellanites vary only from $\delta^{18} \mathrm{O}=31.0 \%$ to $31.8 \%$, indicating formation at $22^{\circ}$ to $25^{\circ} \mathrm{C}$

9. Thermal cherts and porcellanites form by high-temperature chertification due to proximity to intrusive sills, volcanic flows, or hydrothermal emanations. Two analyzed samples have isotopic compositions of $28.9 \%$ and $29.3 \%$, two of the lowest $\delta^{18} \mathrm{O}$ values that we measured, indicating quartz crystallization at $34^{\circ}$ and $32^{\circ} \mathrm{C}$.

10. For quartz cherts, carbonate-replacement cherts formed at the lowest $\mathrm{O}$-isotope model temperatures $\left(7^{\circ}-26^{\circ} \mathrm{C}\right)$, bedded cherts at intermediate temperatures $\left(22^{\circ}-25^{\circ} \mathrm{C}\right)$, and thermal cherts at the highest temperatures $\left(32^{\circ}-34^{\circ} \mathrm{C}\right)$.

11. The co-occurrence of opal-CT and chalcedony with an $8.7 \%$ difference in $\delta^{18} \mathrm{O}$ in shallowly buried chert and porcellanite from Sites 800 and 801 suggests that sediments in the Pigafetta Basin experienced a Tertiary shift to strongly ${ }^{18} \mathrm{O}$-depleted pore waters due to alteration of underlying Aptian to Albian-Cenomanian volcaniclastic deposits after opal-A to opal-CT transformation, but prior to precipitation of microfossil-filling chalcedonic quartz.

\section{ACKNOWLEDGMENTS}

We thank Peter Vrolijk and the analytical staff at Exxon Production Research for the XRD analyses, and Gee Minn Chang of the Center for Isotope Geochemistry, Lawrence Berkeley Laboratory, for his analytical assistance. Eugenio Gonzales and Anne McCaffrey of the Earth Sciences Department, University of California, Santa Cruz, created beautiful thin sections for the petrographic work. R. E. Garrison encouraged this study with helpful discussions and an early review of this manuscript. This study would not have taken place without the Leg 129 shipboard scientific, technical, and operations staff, who made this project possible. The manuscript was reviewed by J. B. Keene, J. R. Hein, and R. Moberly, Jr.; we greatly appreciate their helpful comments, corrections, and criticisms. This research was supported by a JOI/U.S. Science Support Program grant to R. E. Garrison, on behalf of R. J. Behl. This study was also supported, in part, by the Director, Office of Energy Research, Office of Basic Energy Sciences, Engineering and Geosciences Division, of the U.S. Department of Energy under Contract No. DE-ACO3-76SF00098.

\section{REFERENCES}

Audley-Charles, M. G., 1965. Some aspects of the chemistry of Cretaceous siliceous sedimentary rocks from eastern Timor. Geochim. Cosmochim. Acta, 29:1175-1192.

Bailey, E. H., Irwin, W. P., and Jones, D. L., 1964. Franciscan related rocks and their significance in the geology of western California. Calif. Div. Mines Geol. Bull., 183.

Baltuck, M., 1986. Authigenic silica in Tertiary and Upper Cretaceous sediments of the East Mariana Basin, Deep Sea Drilling Project Site 585. In Moberly, R., Schlanger, S. O., et al., Init. Repts. DSDP, 89: Washington (U.S. Govt. Printing Office), 389-398.
Berger, W. H., and von Rad, U., 1972. Cretaceous and Cenozoic sediments from the Atlantic Ocean. In Hayes, D. E., Pimm, A. C., et al., Init. Repts. DSDP, 14: Washington (U.S. Govt. Printing Office), 787-954.

Bramlette, M. N., 1946. The Monterey Formation of California and the origin of its siliceous rocks. Geol. Surv. Prof. Pap. U.S., 212.

Brueckner, H. K., Snyder, W. S., and Boudreau, M., 1987. Diagenetic controls on the structural evolution of siliceous sediments in the Golconda allochthon, Nevada, U.S.A. J. Struct. Geol., 9:403-417.

Chambers, S. R., 1991. Geochemical studies of sediments and interstitial waters from the Kerguelen Plateau and Prydz Bay, Antarctica [Ph.D. dissert.]. Stanford Univ., Stanford, CA.

Clayton, R. N., and Mayeda, T. K., 1963. The use of bromine pentafluoride in the extraction of oxygen from oxides and silicates for isotopic analysis. Geochim. Cosmochim. Acta, 27:43-52.

Clayton, R. N., O'Neil, J. R., and Mayeda, T. K., 1972. Oxygen isotope exchange between quartz and water. J. Geophys. Res., 77:3057-3067.

Davis, E. F., 1918. The radiolarian cherts of the Franciscan group. Univ. Calif. Dept. Geol. Bull., 11.

Flörke, O. W., 1955. Zur frage des "hoch"-cristobalit in opalen, bentoniten und gläsern. Neues. Jahrb. Mineral. Monatsh., 10:217-223.

Folk, R. L.. and Pittman, J. S., 1971. Length-slow chalcedony: a testament for vanished evaporites. J. Sediment. Petrol., 41:1045-1058.

Fujii, N., 1986. Downhole flow of bottom water: implications from temperature logging at Hole 462A, Nauru Basin, Deep Sea Drilling Project Leg 89. In Moberly, R., Schlanger, S. O., et al., Init. Repts. DSDP, 89: Washington (U.S. Govt. Printing Office), 597-601.

Garrison, R. E., 1974. Radiolarian cherts, pelagic limestones and igneous rocks in eugeosynclinal assemblages. In Hsü, K. J., and Jenkyns, H. C. (Eds.), Pelagic Sediments on Land and Under the Sea. Spec. Publ. Int. Assoc. Sedimentol., 1:367-400.

Gieskes, J. M., and Lawrence, J. R., 1981. Alteration of volcanic matter in deep sea sediments: evidence from the chemical composition of interstitial waters from deep sea drilling cores. Geochim. Cosmochim. Acta, 45:1687-1703.

Gibson, T. G., and Towe, K. M., 1971. Eocene volcanism and the origin of Horizon A. Science, 172:152-154.

Grunau, H. R., 1965. Radiolarian cherts and associated rocks in space and time. Eclogae Geol. Helvetiae, 58:157-208.

Heath, G. R., 1973. Cherts from the eastern Pacific, Leg 16, Deep Sea Drilling Project. In van Andel, T. H., Heath, G. R., et al., Init. Repts. DSDP, 16: Washington (U.S. Govt. Printing Office), 609-613.

Heath, G. R., and Moberly, R., Jr., 1971. Cherts from the western Pacific, Leg 7, Deep Sea Drilling Project. In Winterer, E. L., Riedel, W. R., et al., Init. Repts. DSDP, 7: Washington (U.S. Govt. Printing Office), 991-1007.

Hein, J. R., and Karl, S. M., 1983. In lijima, A., Hein, J. R., and Siever, R. (Eds.), Siliceous Deposits in the Pacific Region: Amsterdam (Elsevier), Dev. in Sedimentol. Ser., 36:25-43.

Hein, J. R., Scholl, D. W., Barron, J. A., Jones, M. G., and Miller, J., 1978. Diagenesis of late Cenozoic diatomaceous deposits and formation of the bottom simulating reflector in the southern Bering Sea. Sedimentology, 25:155-181.

Hein, J. R., Vallier, T. L., and Allan, M. A., 1981. Chert petrology and geochemistry, Mid-Pacific Mountains and Hess Rise, Deep Sea Drilling Project Leg 62. In Thiede, J., Vallier, T. L., et al., Init. Repts. DSDP, 62: Washington (U.S. Govt. Printing Office), 711-748.

Hein, J. R., and Yeh, H. W., 1981. Oxygen-isotope composition of chert from the Mid-Pacific Mountains and Hess Rise, Deep Sea Drilling Project Leg 62. In Thiede, J., Vallier, T. L., et al., Init. Repts. DSDP, 62: Washington (U.S. Govt. Printing Office), 749-758.

Hesse, R., 1988. Origin of chert, I. Diagenesis of biogenic siliceous sediments. Geosci. Can., 15:171-192.

Isaacs, C. M., 1981. Field characterization of rocks in the Monterey Formation along the coast near Santa Barbara, California. In Isaacs, C. M. (Ed.), Guide to the Monterey Formation in the California Coastal Area, Ventura to San Luis Obispo. Pacific Sect. AAPG Field Guide, 52:39-54.

1982. Influence of rock composition on kinetics of silica phase changes in the Monterey Formation, Santa Barbara area, California. Geology, 10:304-308.

Jenkyns, H. C., 1986. Pelagic environments. In Reading, H. G. (Ed.), Sedimentary Environments and Facies (2nd ed.): Oxford (Blackwell Sci. Publ.), 343-398. 
Jenkyns, H. C., and Winterer, E. L., 1982. Paleoceanography of Mesozoic ribbon radiolarites. Earth Planet. Sci. Lett., 60:351-375.

Jones, J. B., and Segnit, E. R., 1971. The nature of opal. I. Nomenclature and constituent phases. J. Geol. Soc. Aust., 18:57-68.

Kastner, M., 1981. Authigenic silicates in deep sea sediments: formation and diagenesis. In Emiliani, C. (Ed.), The Sea: The Oceanic Lithosphere (Vol. 7): New York (Wiley), 915-980.

Kastner, M., Keene, J. B., and Gieskes, J. M., 1977. Diagenesis of siliceous oozes. I. Chemical controls on the rate of opal-A to opal-CT transformation-an experimental study. Geochim. Cosmochim. Acta, 41:1041-1059.

Kastner, M., and Siever, R., 1983. Siliceous sediments of the Guaymas Basin: the effect of high thermal gradients on diagenesis. J. Geol., 91:629-641.

Kastner, M., and Stonecipher, S. A., 1978. Zeolites in pelagic sediments of the Atlantic, Pacific and Indian Oceans. In Sand, L. B., Mumpton F. A. (Eds.), Natural Zeolites, Occurrence, Properties, Use: Oxford (Pergammon), 199-220.

Keene, J. B., 1975. Cherts and porcellanites from the North Pacific, DSDP Leg 32. In Larson, R. L., Moberly, R., et al., Init. Repts. DSDP, 32: Washington (U.S. Govt. Printing Office), 429-507.

, 1976. The distribution, mineralogy, and petrography of biogenic and authigenic silica from the Pacific basin [Ph.D. dissert.]. Scripps Inst. of Oceanogr., Univ. of California, San Diego.

- 1983. Chalcedonic quartz and occurrence of quartzine (length-slow chalcedony) in pelagic sediments. Sedimentology, 30:449-454.

Keene, J. B., and Kastner, M., 1974. Clays and formation of deep-sea chert. Nature, 249:754-755.

Knauth, L. P., and Epstein, S., 1975. Hydrogen and oxygen isotope ratios in silica from the Deep Sea Drilling Project. Earth Planet. Sci. Lett., 25:1-10.

, 1976. Hydrogen and oxygen isotope ratios in nodular and bedded cherts. Geochim. Cosmochim. Acta, 40:1095-1108.

Kolodny, Y., and Epstein, S., 1976. Stable isotope geochemistry of deep sea cherts, Geochim. Cosmochim. Acta, 40:1195-1209.

Lancelot, Y., 1973. Chert and silica diagenesis in sediments from the central Pacific. In Winterer, E. L., Ewing, J. I., et al., Init. Repts. DSDP, 17: Washington (U.S. Govt. Printing Office), 377-405.

Lancelot, Y., Larson, R. L., et al., 1990. Proc. ODP, Init. Repts., 129: College Station, TX (Ocean Drilling Program).

Lawrence, J. R., 1989. The stable isotope geochemistry of deep-sea pore water. In Fritz, P., and Fontes, J. C. (Eds.), Handbook of Environmental Isotope Geochemistry (Vol. 3): Amsterdam (Elsevier), 317-356.

Mazzullo, J., Meyer, A., and Kidd, R., 1988. New sediment classification scheme for the Ocean Drilling Program. In Mazzullo, J., and Graham, A. G. (Eds.), Handbook for Shipboard Sedimentologists. ODP Tech. Note, 8: 45-67.

Murata, K. J., and Larson, R. R., 1975. Diagenesis of Miocene siliceous shales, Temblor Range, California. U.S. Geol. Surv. J. Res., 3:553-566.

Murata, K. J., and Nakata, J. K., 1974. Cristobalitic stage in the diagenesis of diatomaceous shale. Science, 184:567-568.

Murray, R. W., Jones, D. L., and Buchholtz ten Brink, M. R., 1990. Diagenetic formation of bedded chert inferred from rare earth, major, and trace element chemistry of the Franciscan Complex, Monterey Group and DSDP cores. Eos, 71:1392. (Abstract)

1992. Diagenetic formation of bedded chert: evidence from chemistry of the chert-shale couplet. Geology, 20:271-274.

O'Neil, J. R., 1986. Appendix: Terminology and standards. In Valley, J. W., H. P., Taylor, Jr., and O'Neil, J. R. (Eds.), Stable Isotopes in High Temperature Geological Processes. Min. Soc. Am. Rev. Mineral., 16:561-570.

Pisciotto, K. A., 1981a. Diagenetic trends in the siliceous facies of the Monterey Shale in the Santa Maria region, California. J. Sediment. Petrol., 28:547-571.

, 1981b. Distribution, thermal histories, isotopic compositions, and reflection characteristics of siliceous rocks recovered by the Deep Sea Drilling Project. In Warme, J.E., Douglas, R. G., and Winterer, E. L. (Eds.), The Deep Sea Drilling Project: a Decade of Progress. Spec. Publ.-Soc. Econ. Paleontol. Mineral, 32:129-147.

Prezbindowski, D., 1980. Microsampling technique for stable isotopic analyses of carbonates. J. Sediment. Petrol., 50:643-644.

Riech, V., and von Rad, U., 1979. Silica diagenesis in the Atlantic Ocean: diagenetic potential and transformations. In Talwani, M., Hay, W., and Ryan, W.B.F. (Eds.), Deep Drilling Results in the Atlantic Ocean: Continents, Margins, and Paleoenvironments. Am. Geophys. Union, Maurice Ewing Ser., 3:315-340.

Savin, S. M., 1977. The history of the earth's surface temperature during the past 100 million years. Annu. Rev. Earth Planet. Sci., 5:319-355.

Sheppard, S.M.F. 1986. Characterization and isotopic variations in natural waters. In Ribbe, P. H. (Ed.), Stable Isotopes in High Temperature Geological Processes. Rev. Mineral., 16:165-184.

Shipboard Scientific Party, 1990. Site 802. In Lancelot, Y., Larson, R. L., et al., Proc. ODP, Init. Repts., 129: College Station, TX (Ocean Drilling Program), $171-243$.

Thurow, J., 1988. Diagenetic history of Cretaceous radiolarians, North Atlantic Ocean, (ODP Leg 103 and DSDP Holes 398D and 603B. In Boillot, G., Winterer, E. L., et al., Proc. ODP, Sci. Results, 103: College Station, TX (Ocean Drilling Program), 531-555.

Trümpy, R., 1960. Paleotectonic evolution of the central and western Alps. Geol. Soc. Am. Bull., 71:843-908.

von Rad, U., and Rösch, H., 1974. Petrography and diagenesis of deep-sea cherts from the central Atlantic. In Hsü, K. J., and Jenkyns, H. C. (Eds.), Pelagic Sediments on Land and Under the Sea. Spec. Publ. Int. Assoc. Sedimentol., 1:327-347.

Wise, S. W., and Weaver, F. M., 1974. Chertification of oceanic sediments. In Hsü, K. J., and Jenkyns, H. C. (Eds.), Pelagic Sediments on Land and Under the Sea. Spec. Publ. Int. Assoc. Sedimentol., 1:301-326.

Date of initial receipt: 26 June 1991

Date of acceptance: 17 March 1992

Ms 129B-112 


\section{R. J. BEHL, B. M. SMITH}
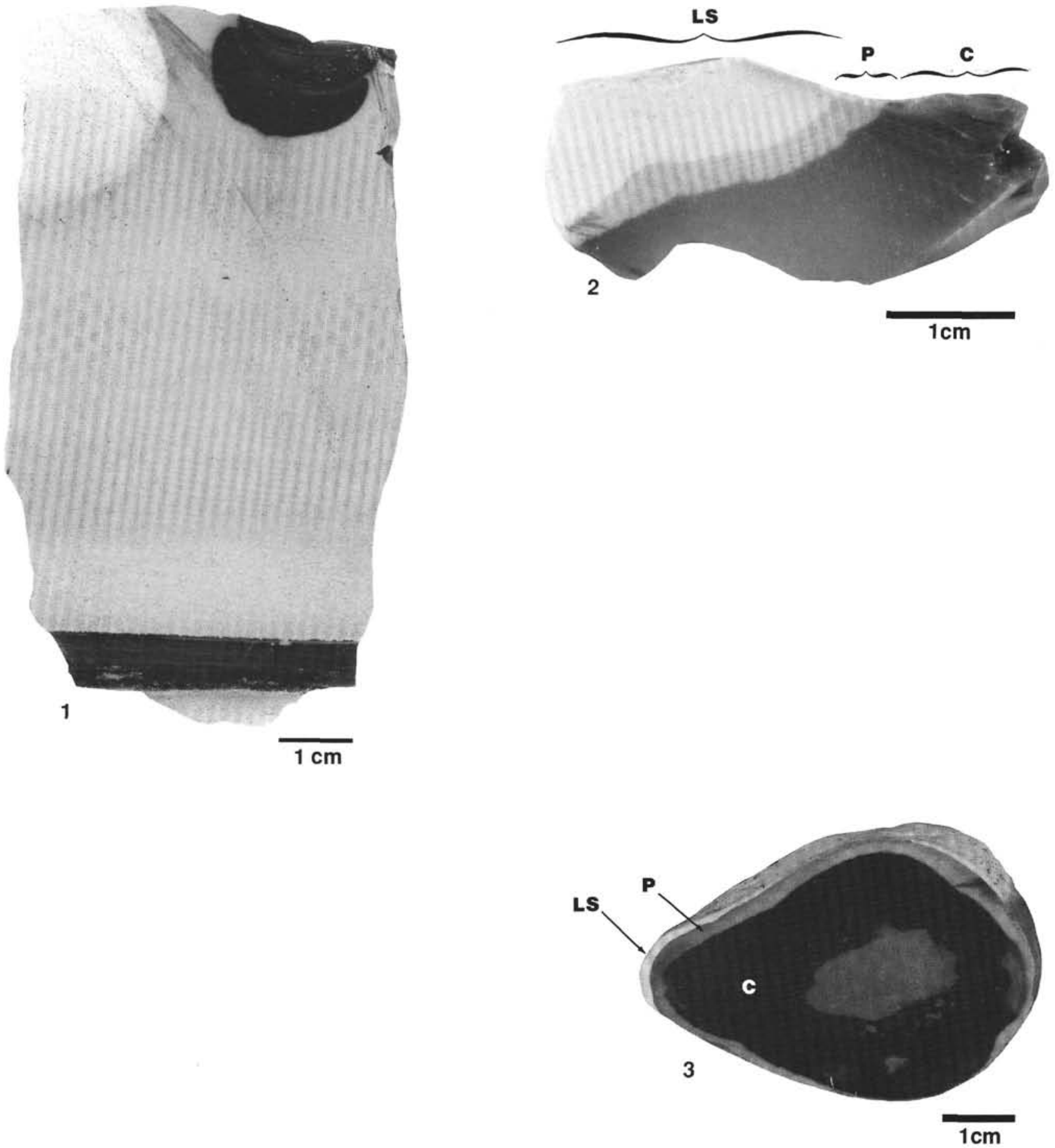

Plate 1. Carbonate-replacement chert and porcellanite. 1. Black quartz chert formed at foraminifer-rich lamination (bottom) and burrow (top); upper Albian, Sample 129-800A-21R-1, 87-99 cm. 2. Three-part zonation of black or dark gray quartz chert (C), light gray opal-CT and quartz porcellanite (P), and white siliceous limestone (LS); upper Albian, Sample 129-800A-21R-1,32-35 cm. 3. Black quartz chert (flint) from the Upper Cretaceous Chalk of Southwest England, near Marlborough. This flint displays similar three-part zonation to that in (2) plus a center rich in chalk inclusions. (4-7) BSEM photomicrographs of Cenomanian Sample 129-800A-14R-1, 115-116 cm. 4. Quartz chert (QC) and transition zone consisting of opal-CT (CT), chalcedonic quartz (Ch), and calcite (cc). Note dark gray opal-CT spherules and foraminifer chambers differently filled with opal-CT, chalcedony, and calcite. 5. Chalcedony spherules (Ch) nucleate on and grow radially outward from opal-CT lepispheres (CT). Note porous (dark gray), isopachous rim to chalcedony spherules in center has similar gray shade as opal-CT. 6. Late-stage precipitation of calcite (cc) into void. 7. Chalk inclusion in dense, quartz chert (QC). 

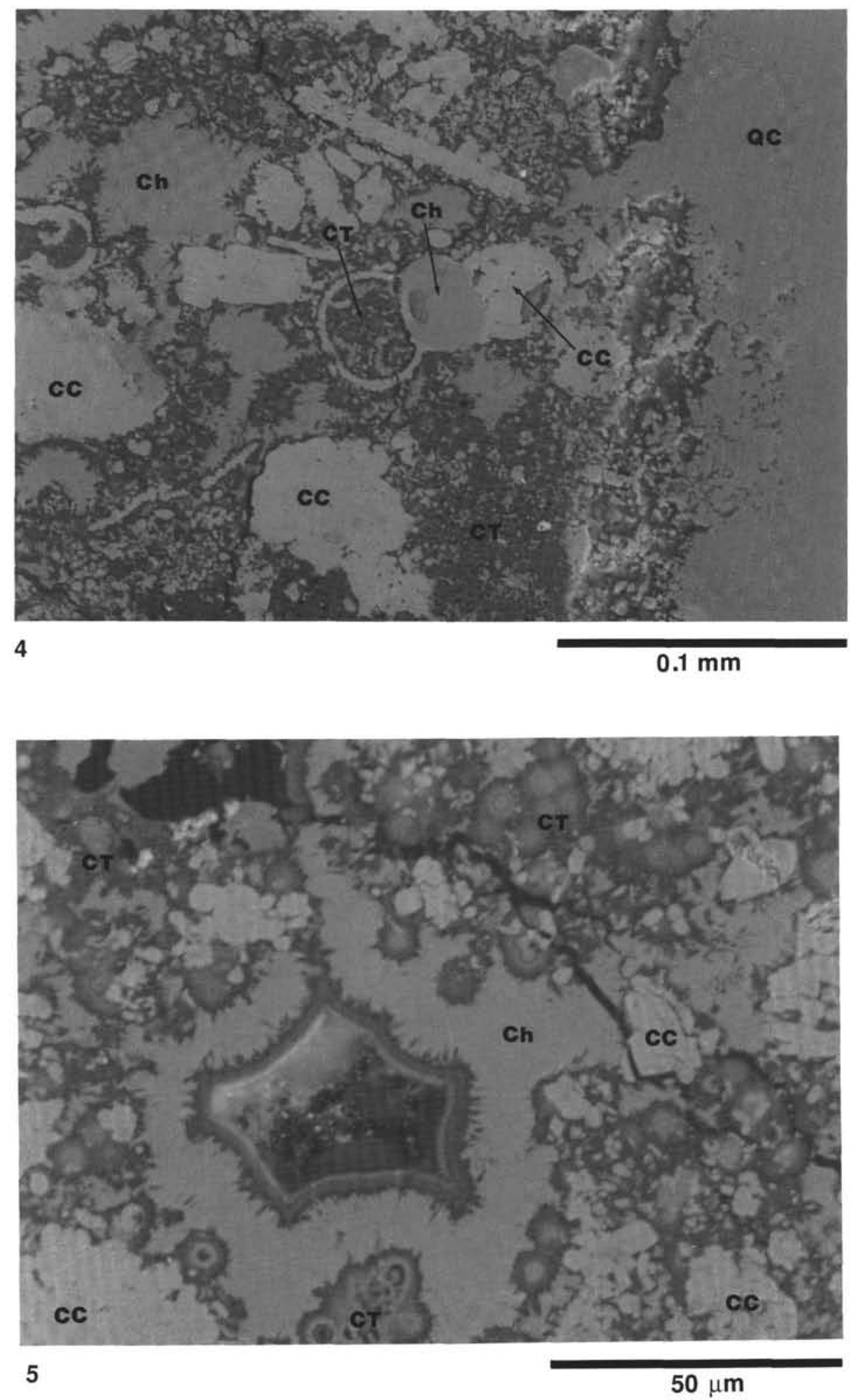

Plate 1 (continued). 

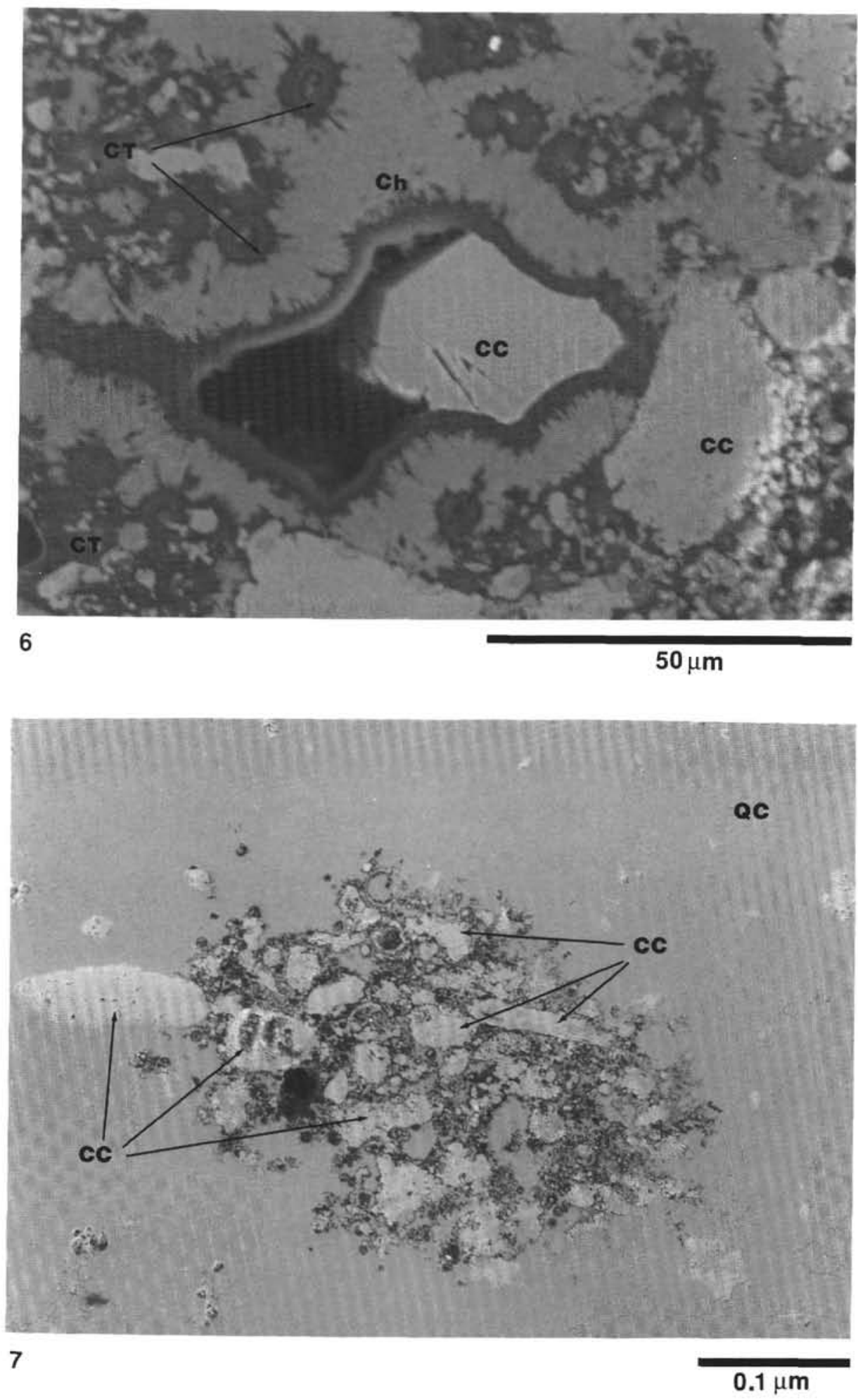

Plate 1 (continued). 
[BLANK PAGE] 
R. J. BEHL, B. M. SMITH
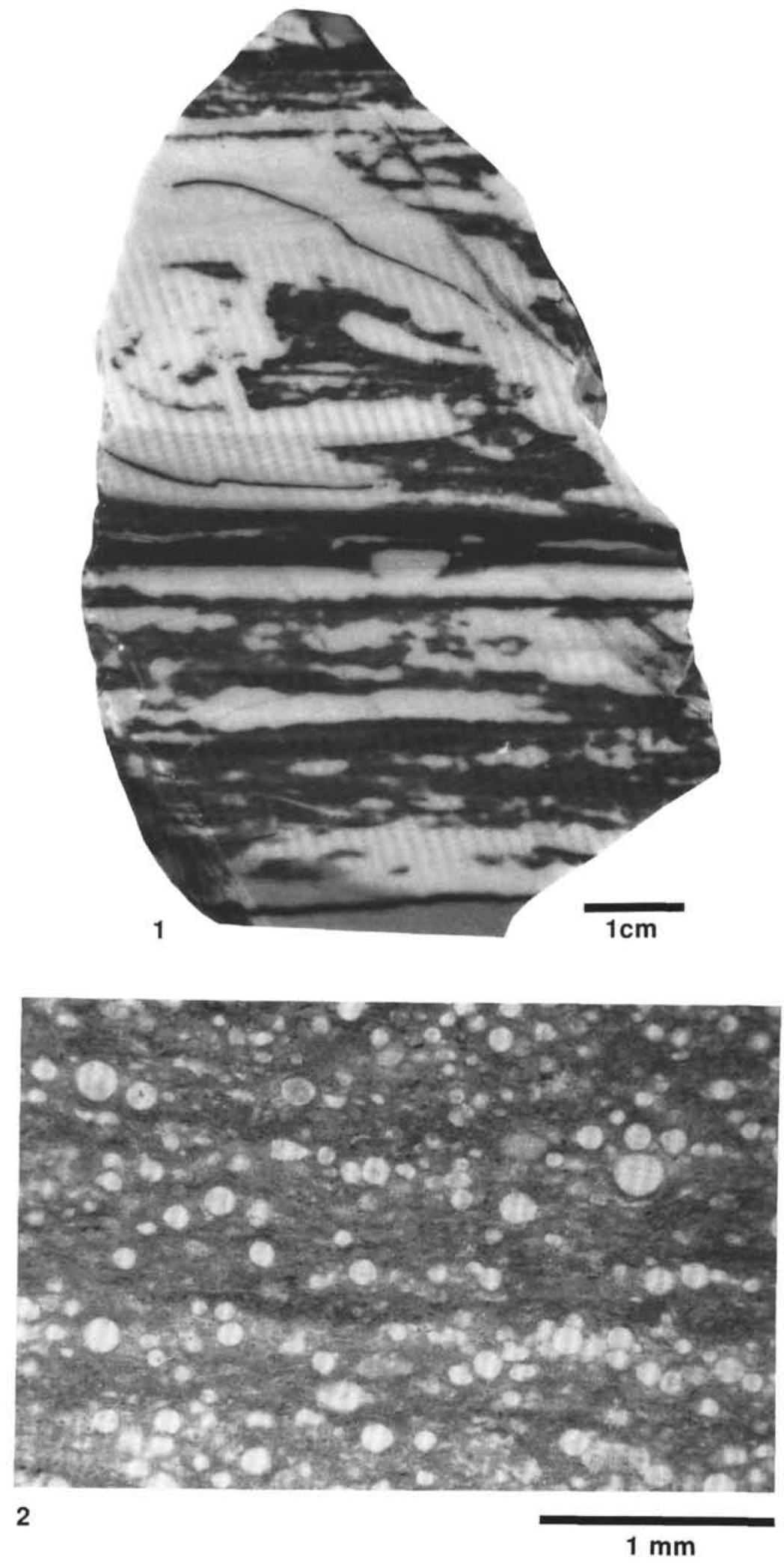

Plate 2. 


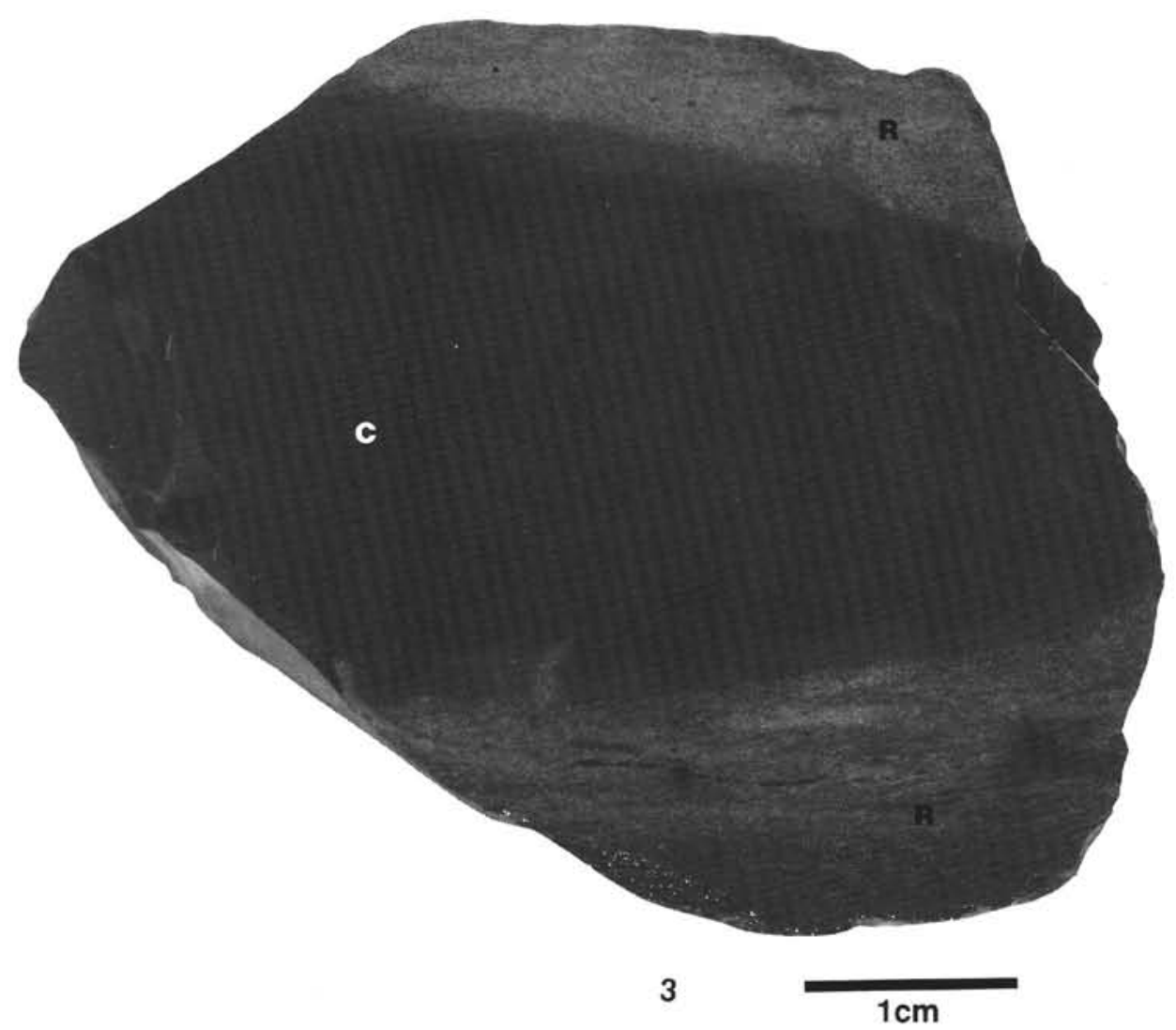

Plate 2 (continued).

Plate 2. Bedded chert, porcellanite, and radiolarite. 1. Mottled and banded opal-CT radiolarian chert. Mottling reflects differential reduction of oxides at burrows, laminations, and fractures; Campanian-Maestrichtian, Sample 129-801A-7R-4, 35-45 cm. 2. Plane light photomicrograph of quartz-phase radiolarian chert; Berriasian-Valanginian, Sample 129-801B-16R-1, 27-31 cm. 3. Dense, radiolarian chert (C) band with discordant diagenetic boundary with porous radiolarite (R), showing cross-cutting silicification; Berriasian-Valanginian, Sample 129-801B-17R-1, 29-33 cm. 4. Transition from pelagic clay with zeolites (Unit I ) to radiolarian clay (45\%-50\% radiolarians) at $22 \mathrm{~cm}$, and to opal-CT chert and porcellanite (Unit II) at $29 \mathrm{~cm}$; Campanian-Maestrichtian, interval 129-801A-7R-4, 13-42 cm. 5. SEM photomicrograph of radiolarian filled with uncompacted mixture of clay minerals and opal-CT, surrounded by chalcedonyfilled casts of radiolarians in opal-CT matrix containing only minor clay minerals; Cenomanian chert, Sample 129-800A-12R-1, 1-4 cm. 6. Photomicrograph of nassellarian radiolarian filled with clay- and iron-oxide-rich quartz, whereas all surrounding radiolarians are filled with chalcedony cement. Plane light; Berriasian-Valanginian?, Sample 129-800A-58R-1, 33-36 cm. 
R. J. BEHL, B. M. SMITH
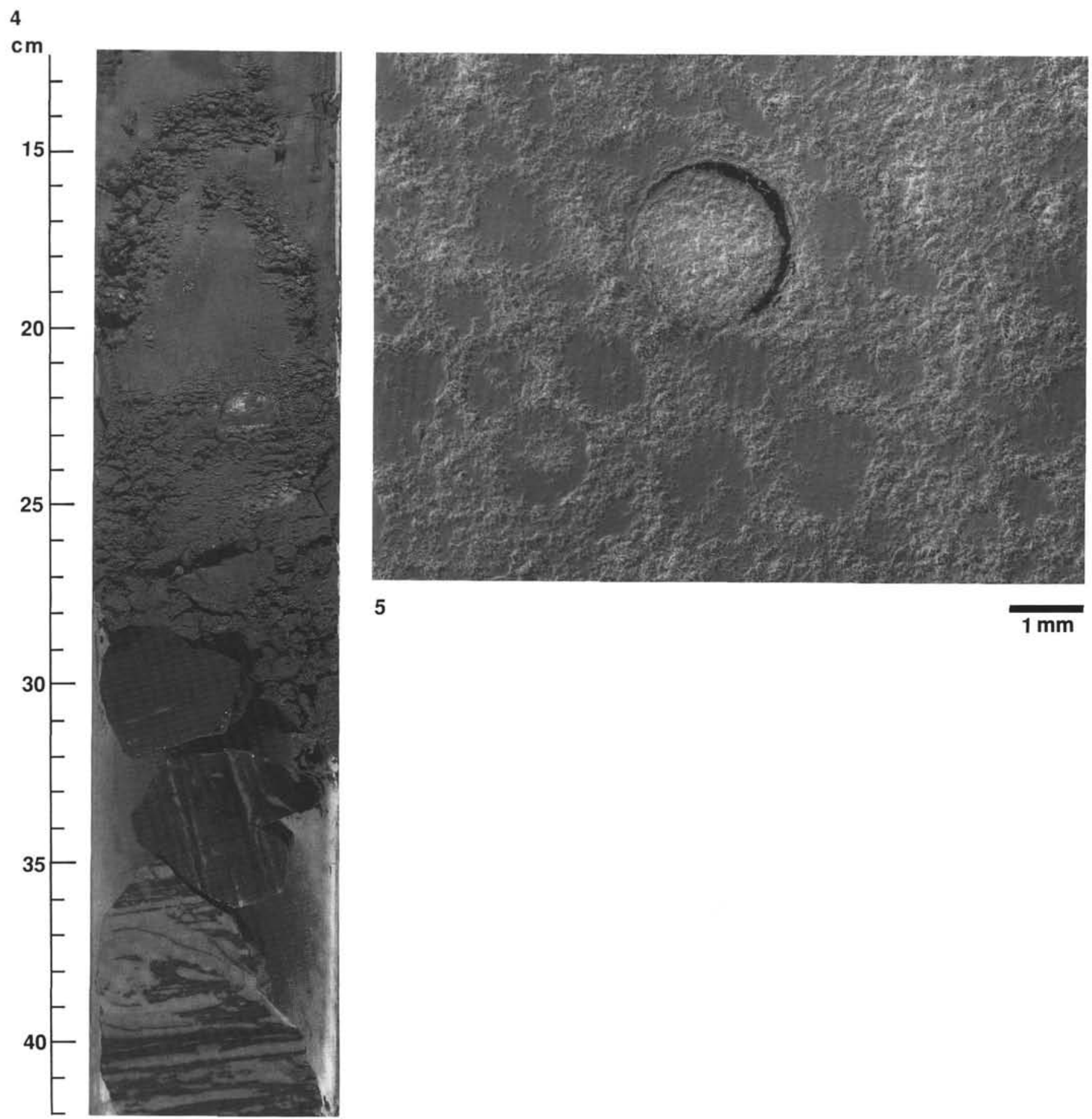

Plate 2 (continued). 


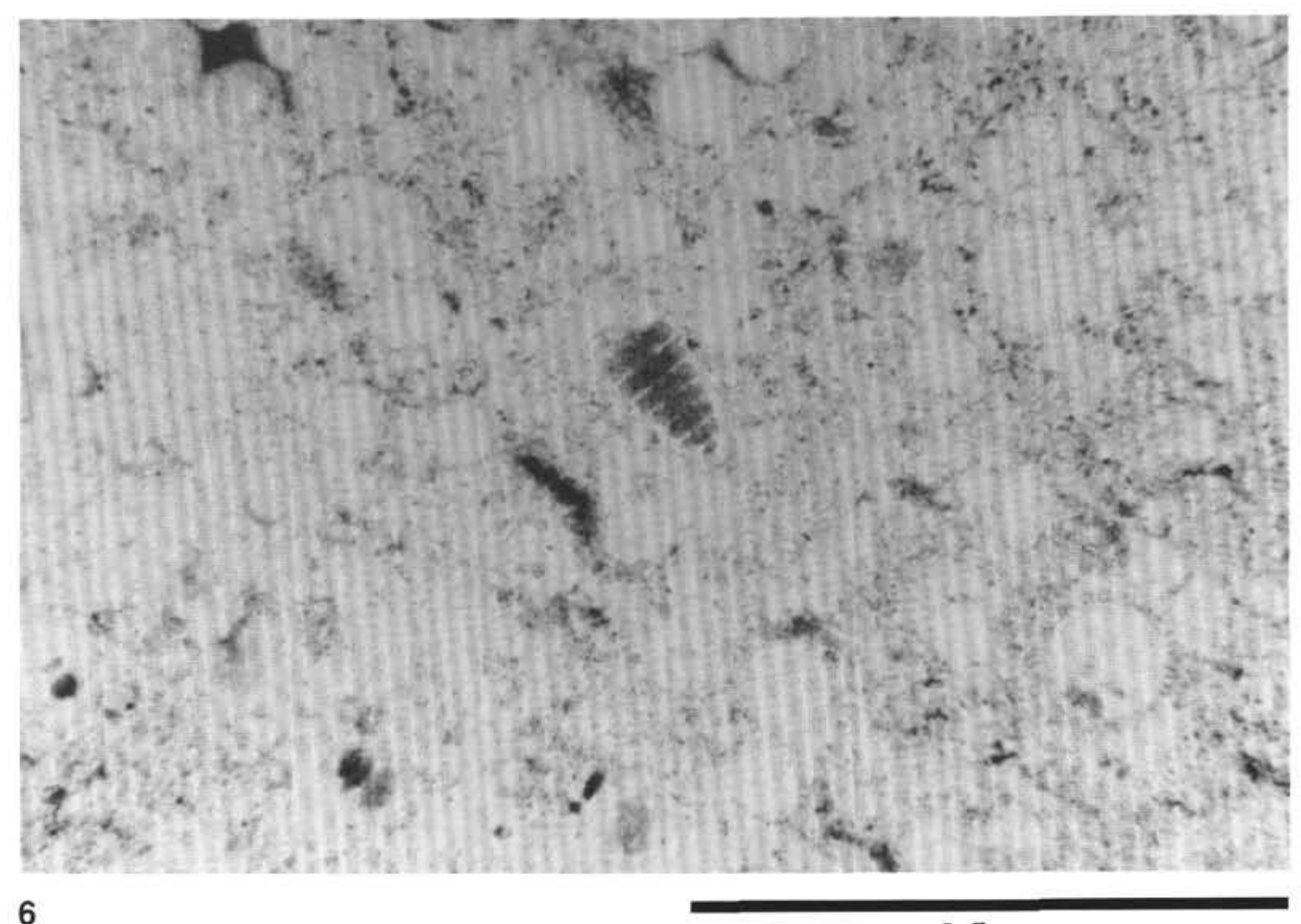

6

$0.5 \mathrm{~mm}$

Plate 2 (continued). 


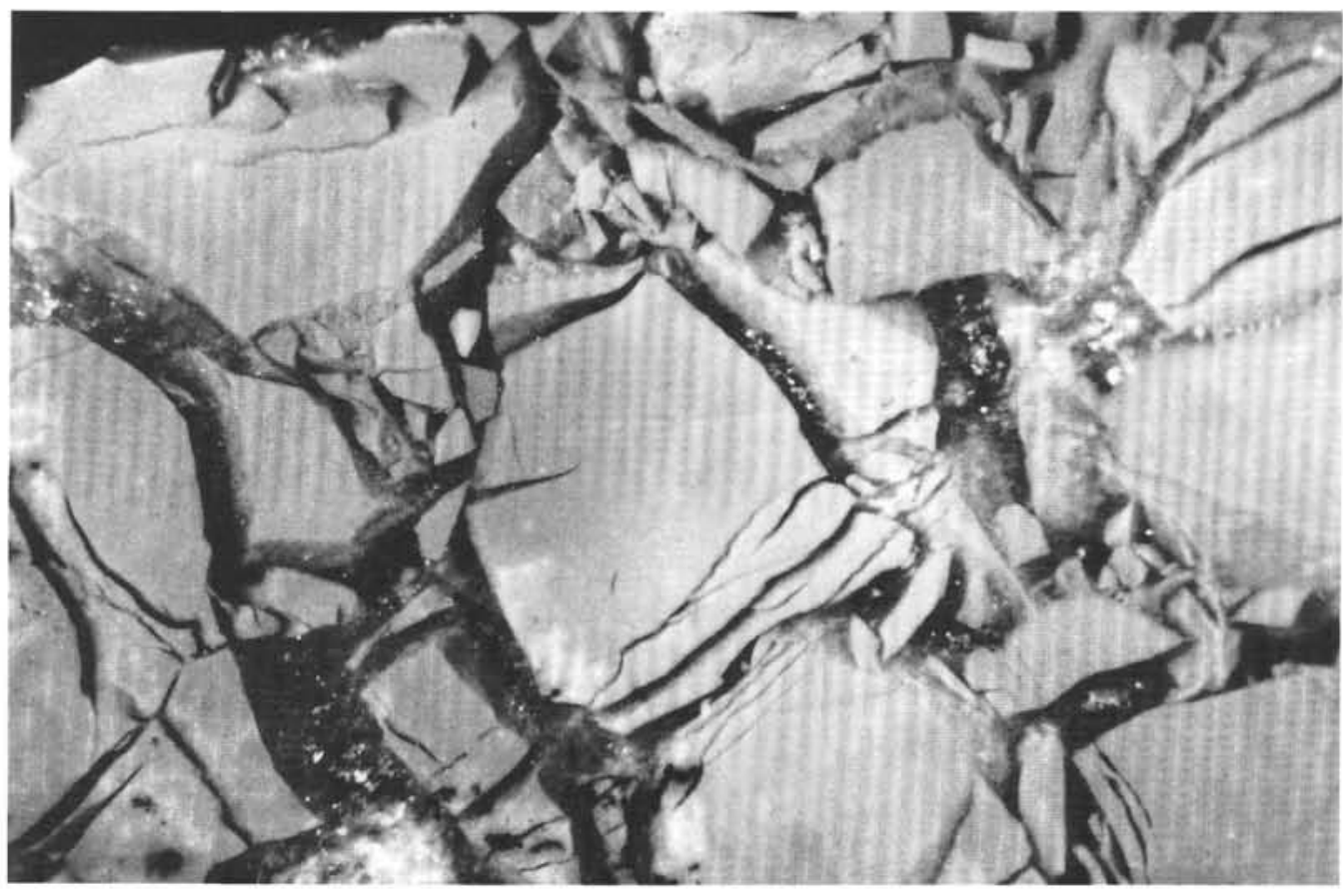

1

$1 \mathrm{~cm}$

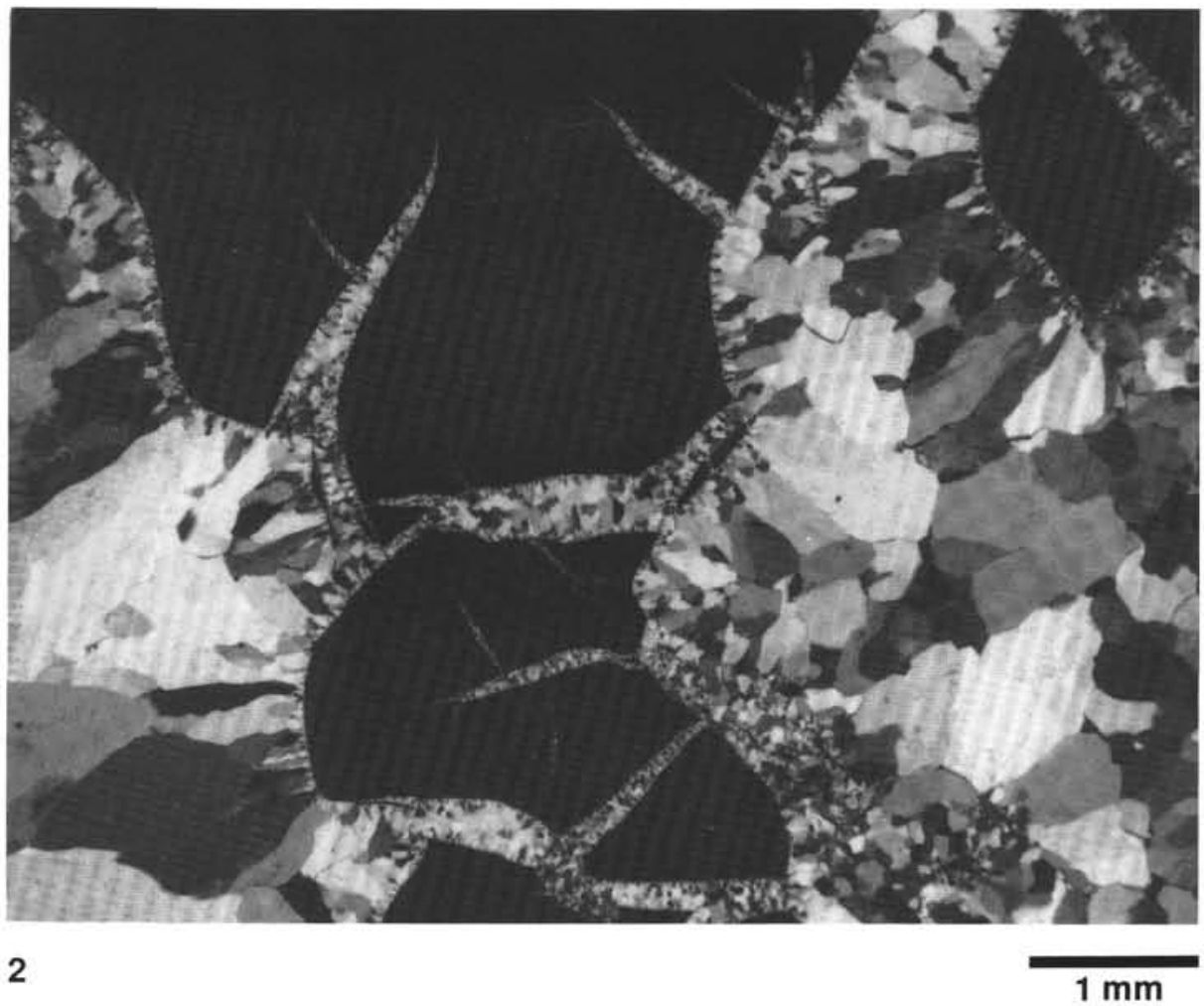

Plate 3. Thermal cherts and porcellanites. 1. Thermal chert breccia formed by silicification and desiccation of pelagic clay deposited between basalt flows. Fragments are replaced and cemented by quartz; Bathonian-Callovian, Sample 129-801B-37R-1, 24-26 cm. 2. Photomicrograph of (1). Note inward-tapering desiccation fractures. Quartz is cryptocrystalline to microcrystalline in silicified pelagic clay fragments and megacrystalline in fracture-filling cement. Crossed nicols. 3. Note the relatively uncompacted aspect ratio $(\leq 3: 1$, horizontal:vertical) of burrows in this interflow thermal porcellanite (burrow boundaries outlined for clarity). Burrows in the overlying "normal" bedded radiolarites are compacted to approximately 10:1 ratio (compare with fig. 12 in "Site 801" chapter, Lancelot, Larson, et al., 1990); Bathonian-Callovian, Sample 129-801B-39R-1, 27-32 cm. 4. Quartz-replaced and -cemented, goethite-rich hydrothermal deposit. Sample 129-801C-4R-1, 69-71 cm. 5. SEM photomicrograph of (D), showing goethite (G) and megaquartz (Q). 6. Upper microcrystalline (>15 mm) to megacrystalline texture of quartz in thermal cherts is distinct from the lower microcrystalline $(<5 \mathrm{~mm})$ to chalcedonic texture of bedded or carbonate-replacement cherts. Crossed nicols; Berriasian-Valanginian?, Sample 129-800A-57R-1, 8-11 cm. 

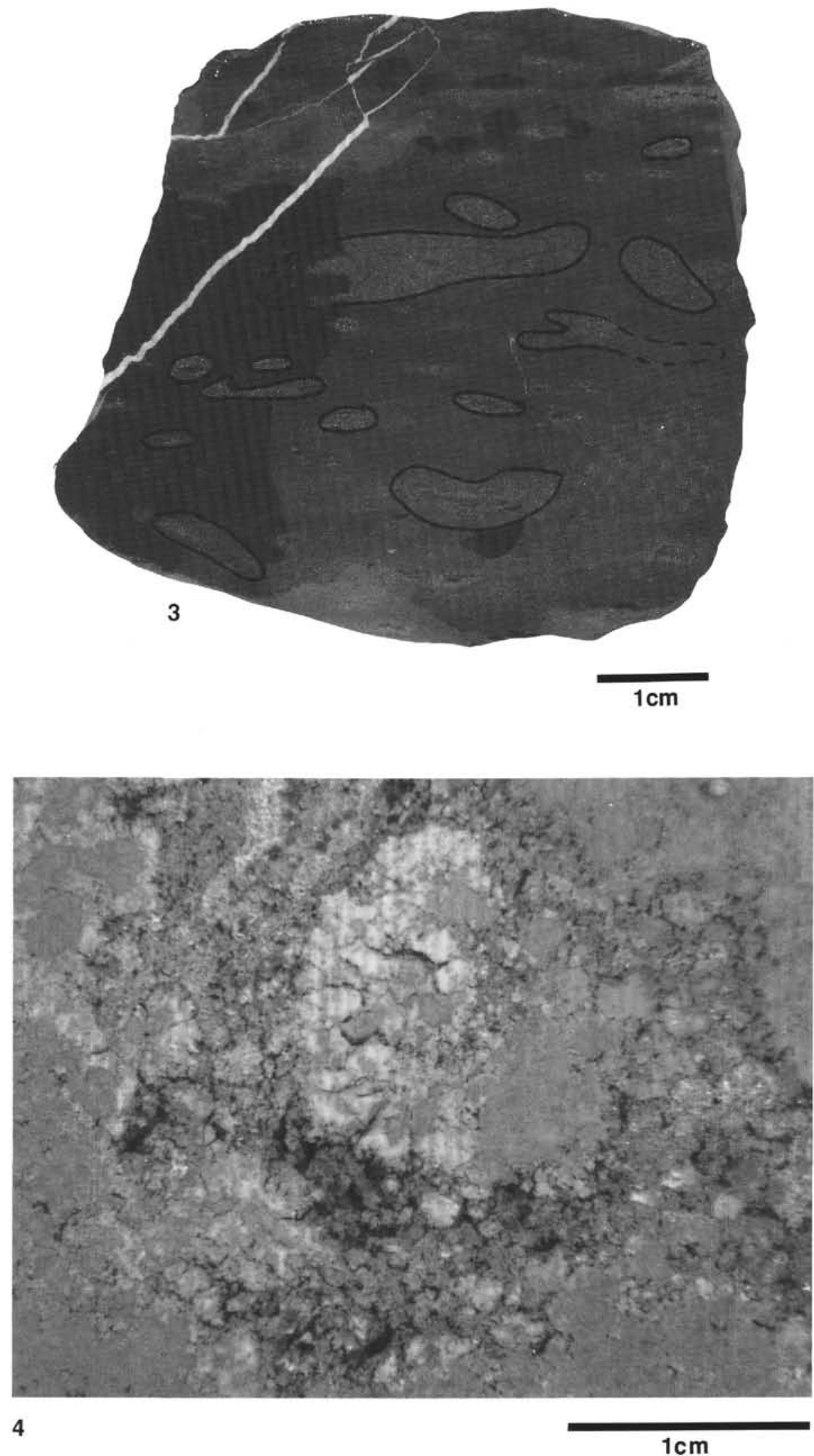

Plate 3 (continued). 

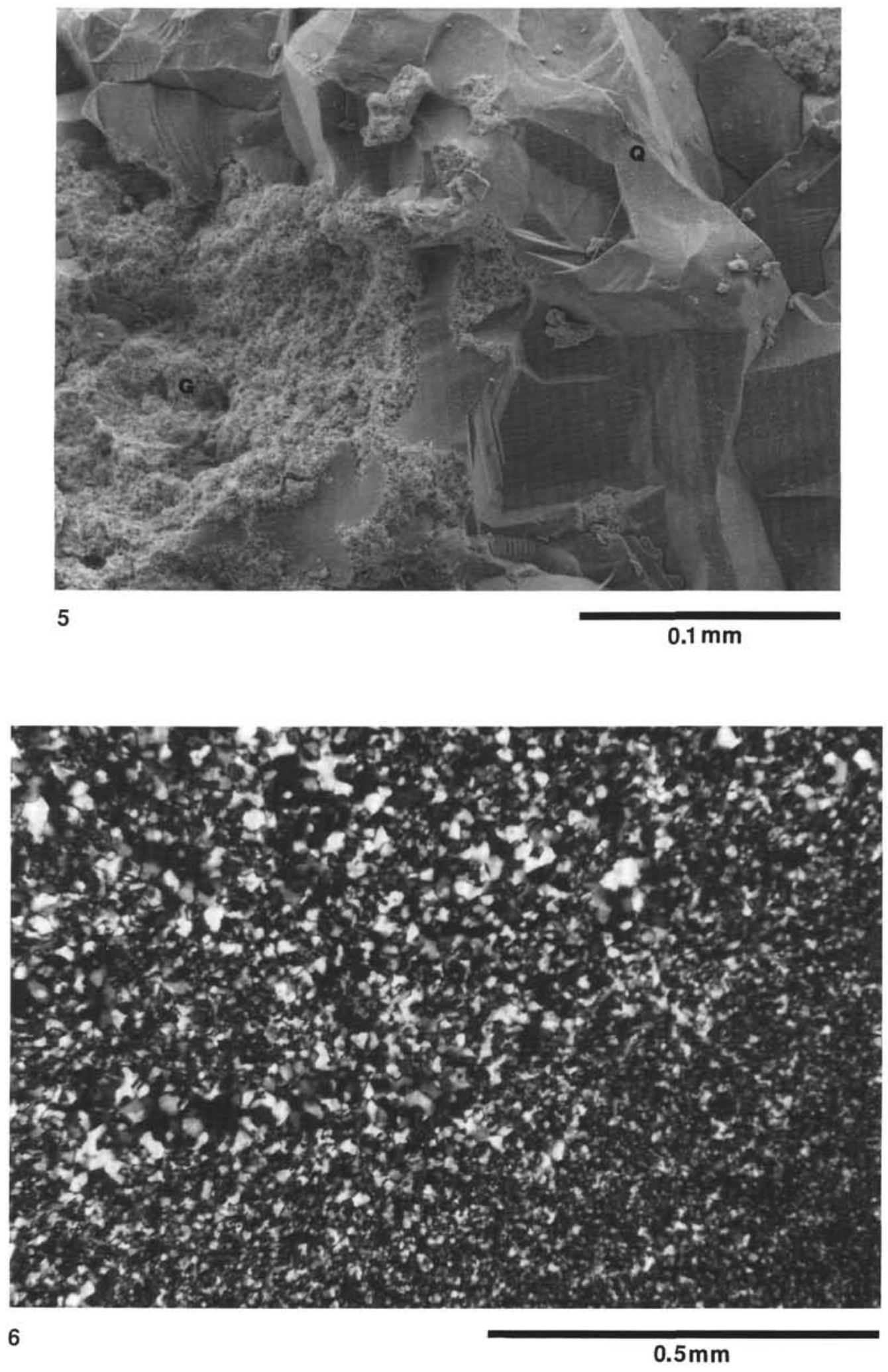

Plate 3 (continued). 
[BLANK PAGE] 


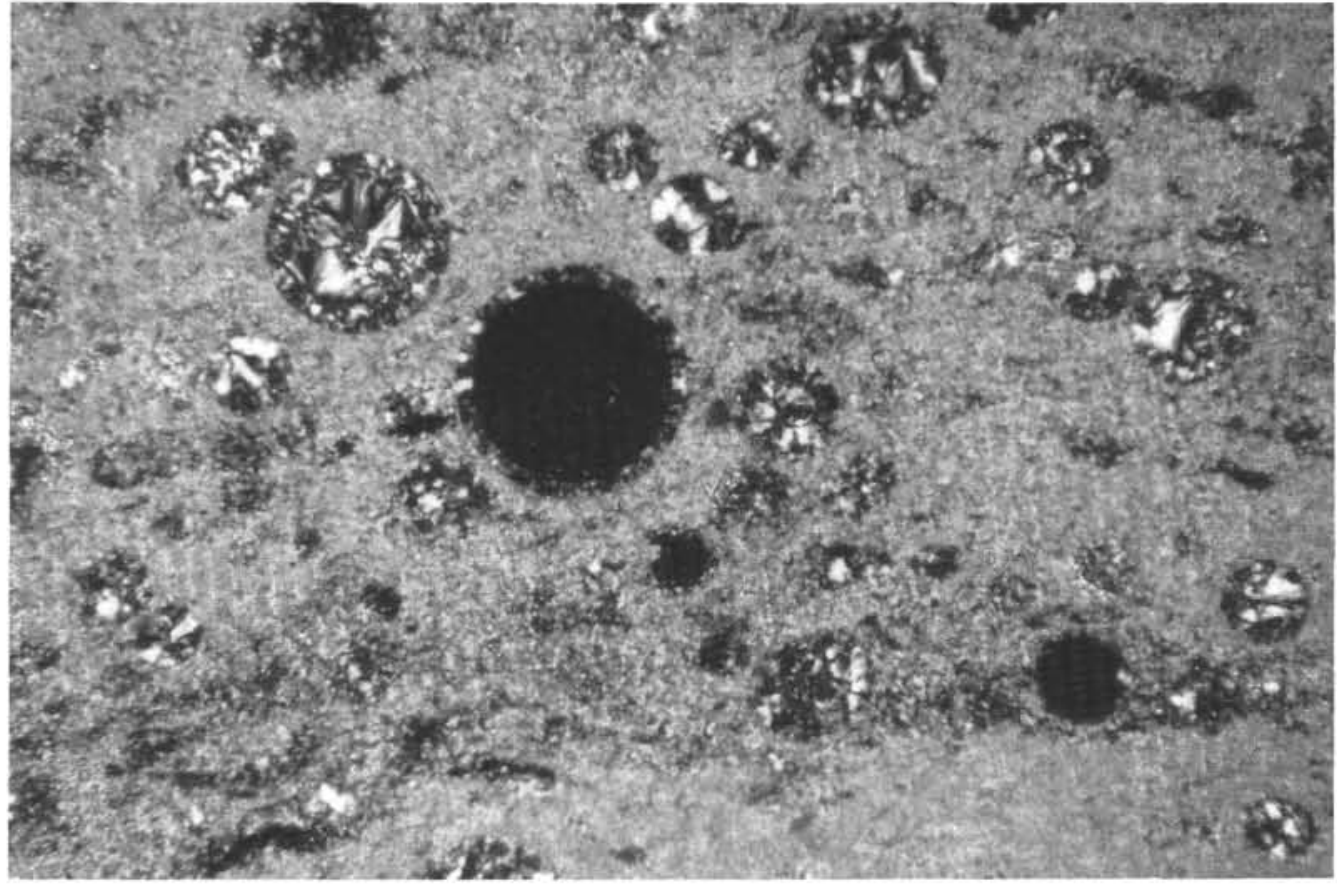

1

$0.1 \mathrm{~mm}$

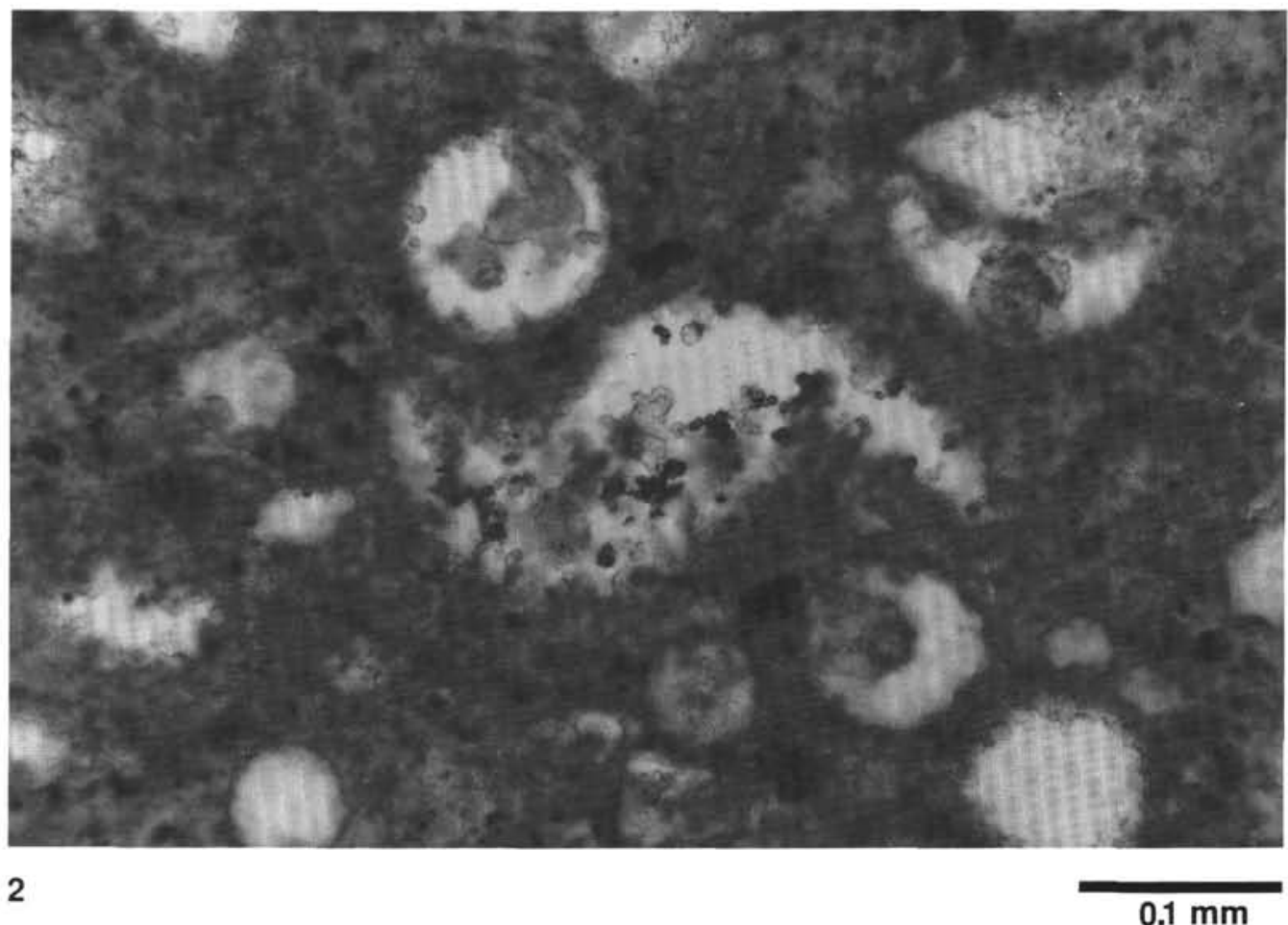

Plate 4. Photomicrographs of some stages of radiolarian diagenesis discussed in the text. (1) and (5) are with crossed nicols. (2), (3), and (5) are with plane light. 1. Radiolarian tests in opal-CT and micrite matrix are replaced by chalcedony, and filled with chalcedony cement (fibrous) or by a sedimentary mixture of opal-CT and clay minerals (black, pseudoisotropic); Cenomanian, Sample 129-800A-13R-1, 29-32 cm. 2. Compacted radiolarian molds filled with opal-CT lepispheres and clear chalcedony cement; lower Aptian, Sample 129-800A-30R-2, 1-3 cm. 3. Nassellarian radiolarian test replaced by opal-CT, partly filled by opal-CT lepispheres, and then completely filled by clear, chalcedony cement; upper Albian, Sample 129-800A-17R-1, 44-46 cm. 4. Radiolarian-filling chalcedony spherules first nucleated on opal-CT lepispheres; lower Aptian, Sample 129-800A-30R-1, 75-77 cm. 5 . Nassellarian radiolarian with three types of fill-micrite and opal-CT sedimentary matrix, opal-CT lepispheric cement, and chalcedony cement; Cenomanian, Sample 129-800A-14R-1, 45-47 cm. 

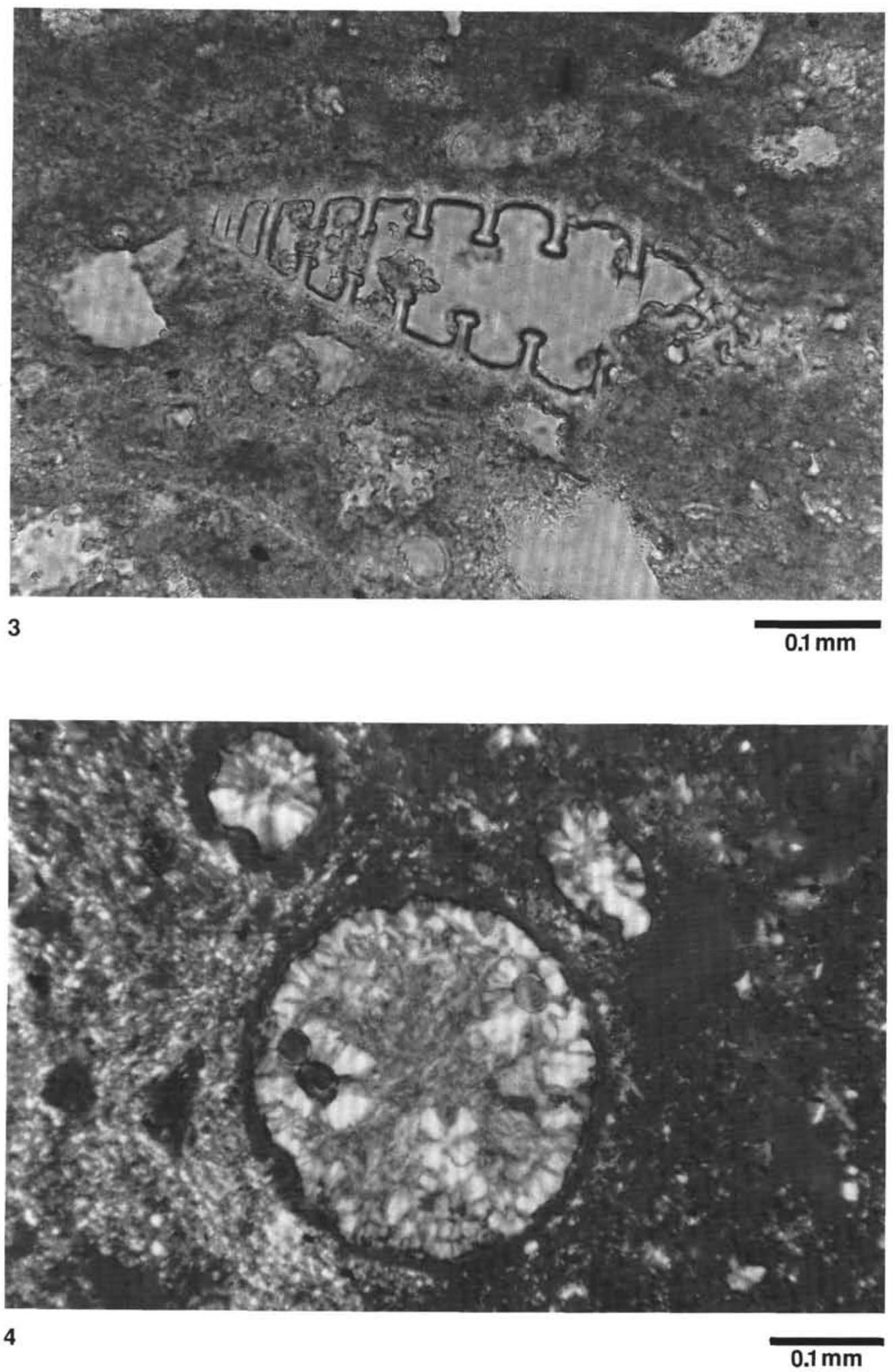

Plate 4 (continued). 
R. J. BEHL, B. M. SMITH

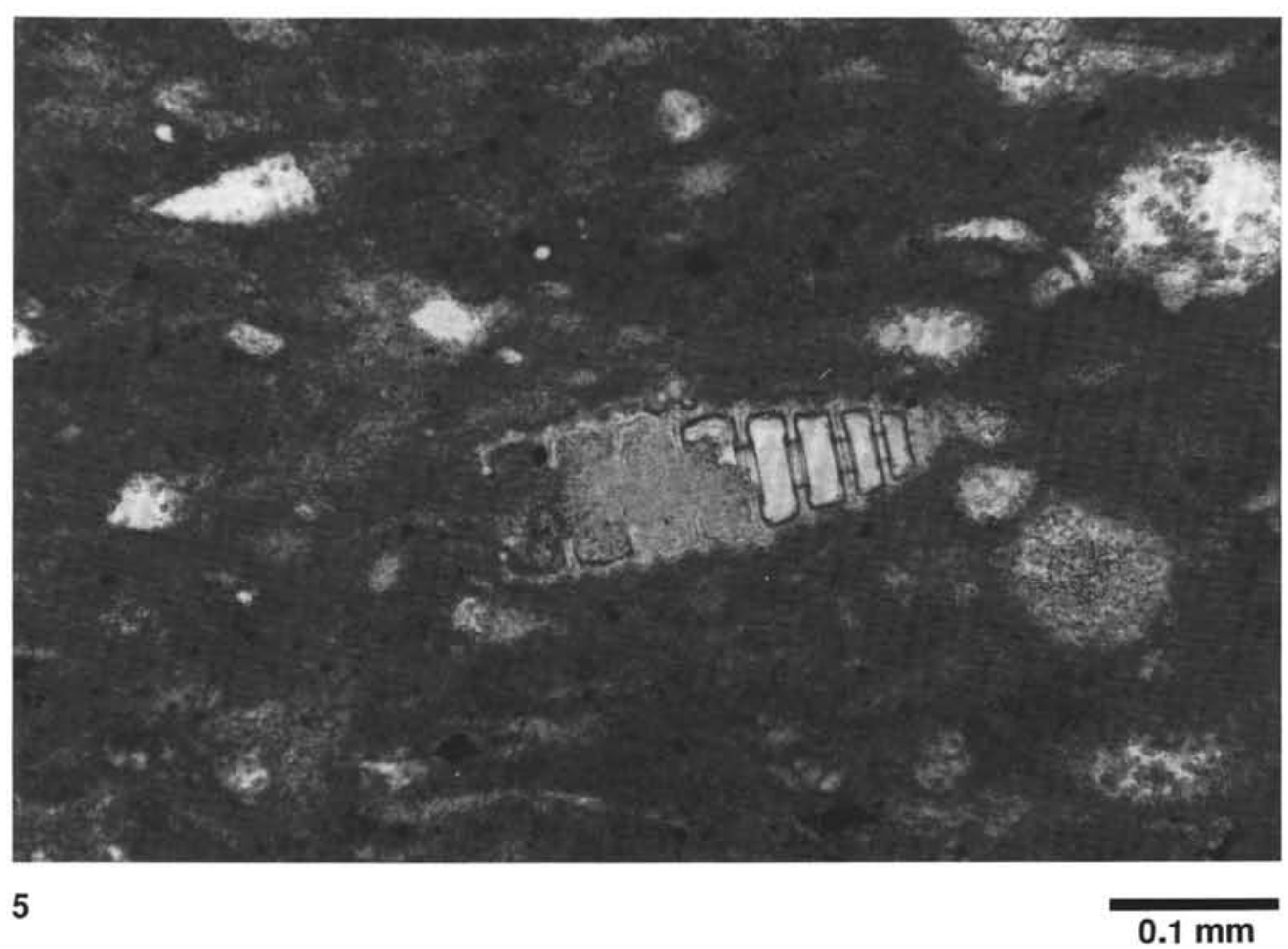

Plate 4 (continued). 
[BLANK PAGE] 


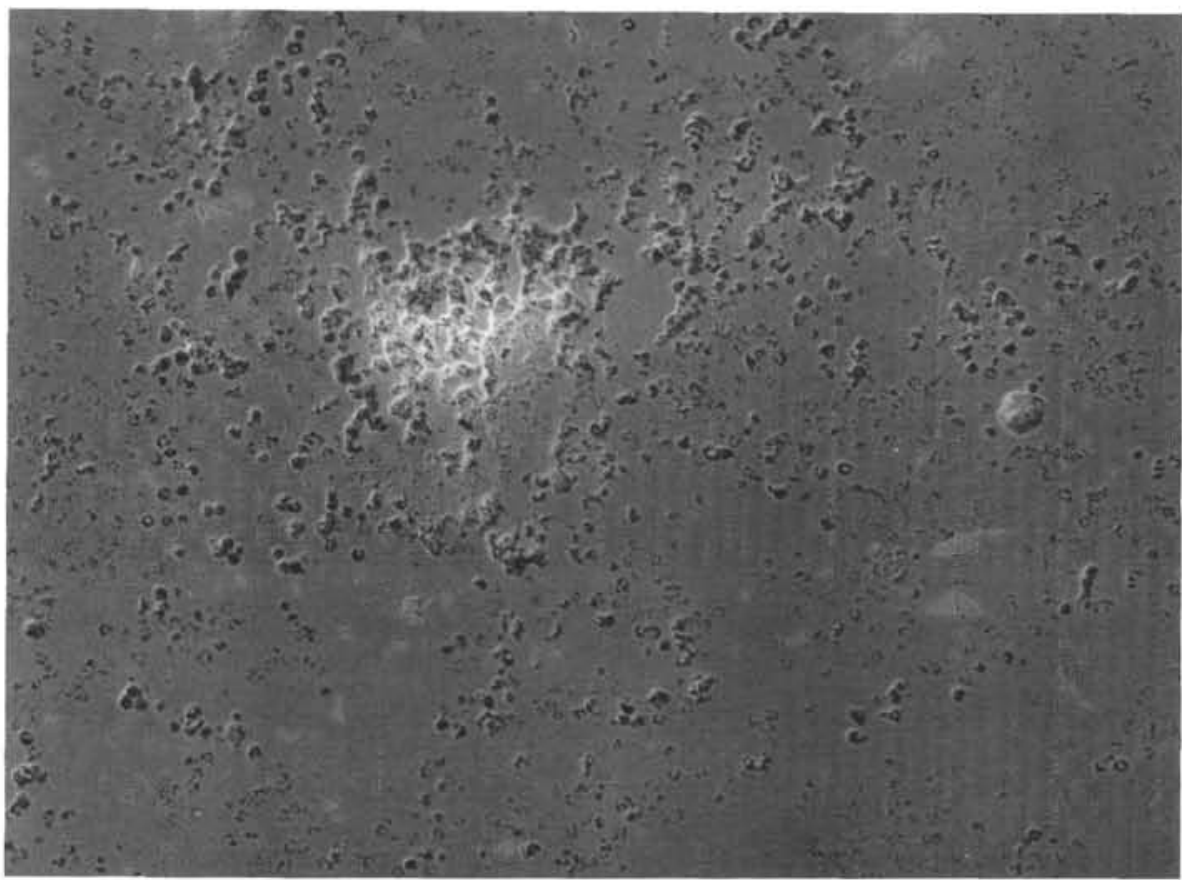

1

$100 \mu \mathrm{m}$

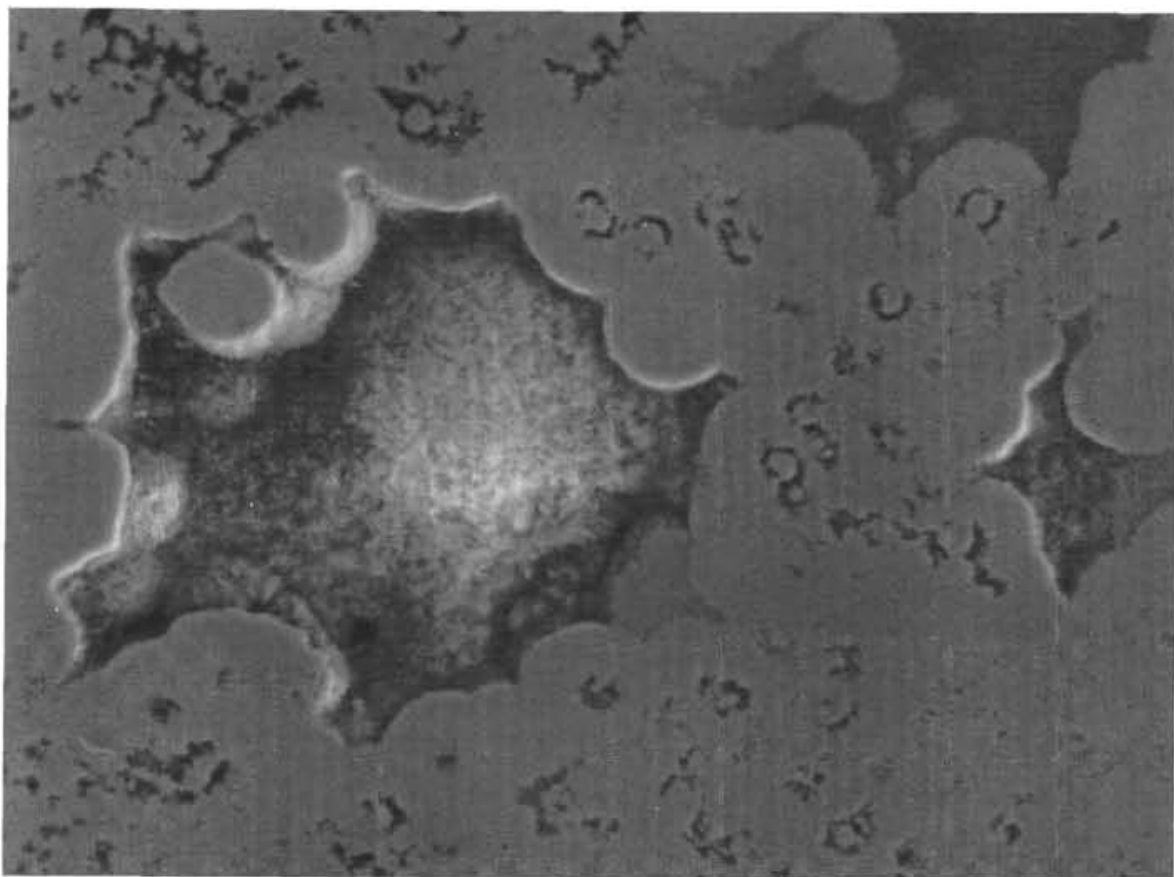

\section{$50 \mu \mathrm{m}$}

Plate 5. Examples of secondary moldic porosity formed by opal-CT to quartz transformation in a closed system, isolated from precipitation of additional silica from advecting pore water. 1. BSEM photomicrograph of molds of opal-CT lepispheres in microcrystalline quartz chert; late Albian, Sample 129-800A-18R-2, 6-8cm. 2. BSEM photomicrograph of shell-like, spheroidal micropores at the center of chalcedony spherules. Same sample as (1). 3. BSEM photomicrograph of nassellarian radiolarian filled with chalcedonic quartz and surrounded by microcrystalline quartz chert. Site of the radiolarian test is marked by dense chalcedony rim and continuous, complex micropore. Replacement of opal-CT test with chalcedony in a closed system resulted in volume reduction and development of secondary pore space. Same sample as (1). 4. Light photomicrograph of secondary porosity outlining a radiolarian cast. Note isolated lepisphere molds distributed through microcrystalline quartz matrix. Plane light; Cenomanian, Sample 129-800A-16-1, 1-3 cm. 

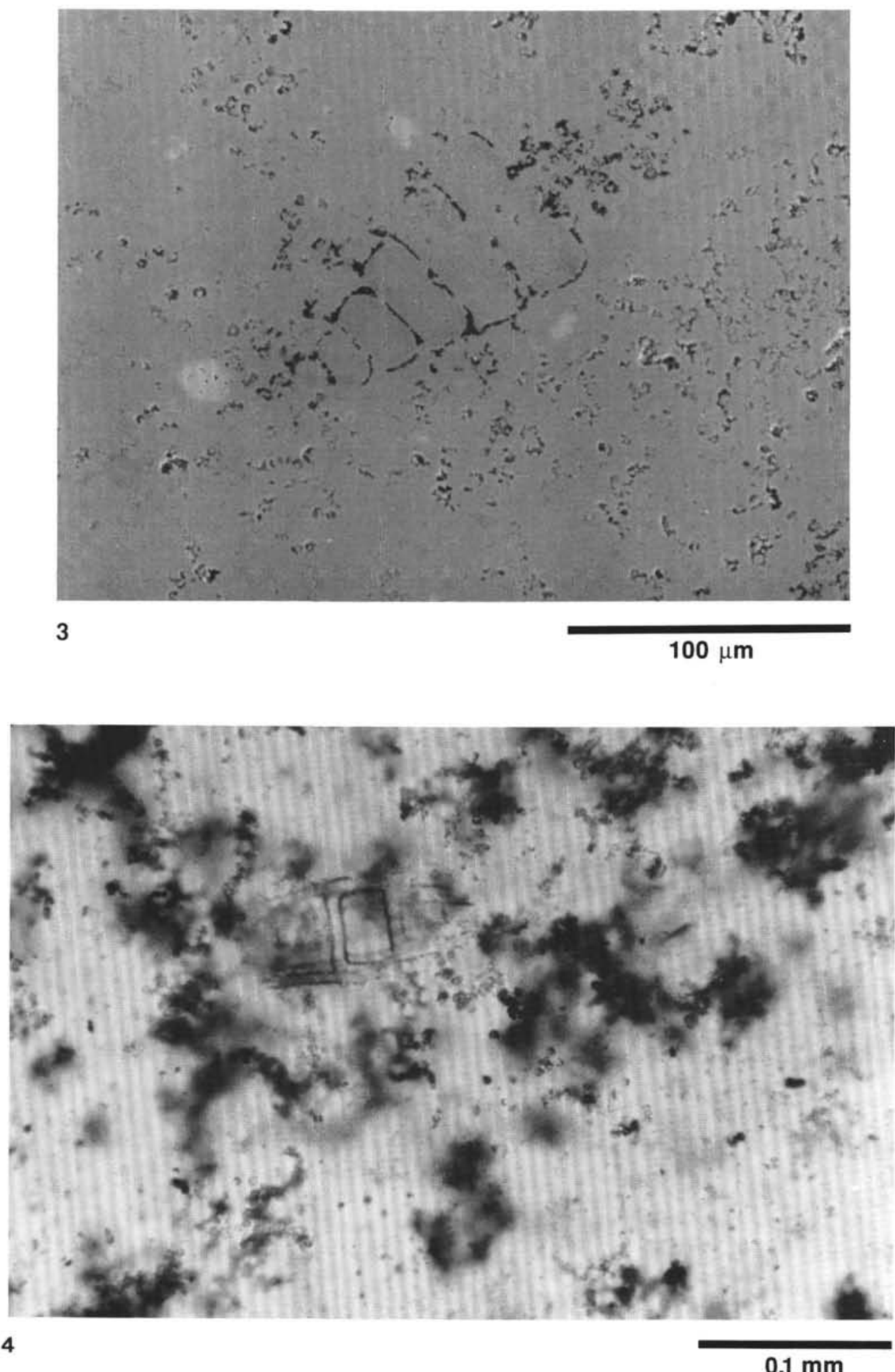

Plate 5 (continued). 